Supporting Information

\title{
Enantioselective C2-Allylation of Benzimidazoles Using 1,3-Diene Pronucleophiles
}

\author{
James Levi Knippel, Yuxuan Ye and Stephen L. Buchwald* \\ Department of Chemistry, Massachusetts Institute of Technology, Cambridge, Massachusetts 02139, United States \\ Correspondence to: sbuchwal@mit.edu
}




\section{Table of Contents}

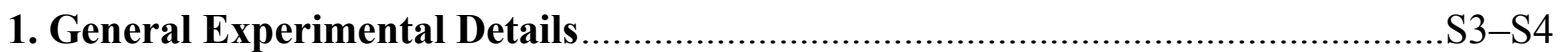

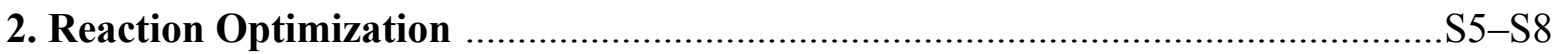

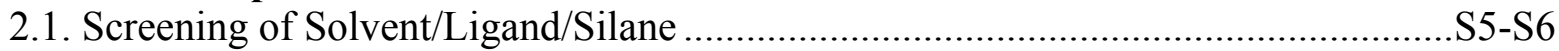

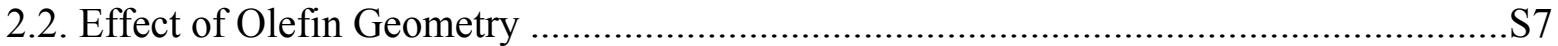

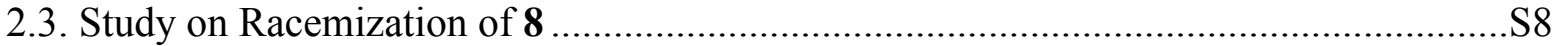

3. Synthesis and Characterization of Starting Materials ......................................S9-S18

3.1. Synthesis and Characterization of $N$-OPiv Benzimidazoles...................................S10-S15

3.2. Synthesis and Characterization of 1,3-Butadienes ............................................S160-S18

4. Benzimidazoles Allylation with Dienes and Characterization of Products.......S19-S35

4.1. General Procedure D for the Allylation of $N$-OPiv Benzimidazoles ...........................S20

4.2 Characterization of Allylation Products................................................................S20-S35

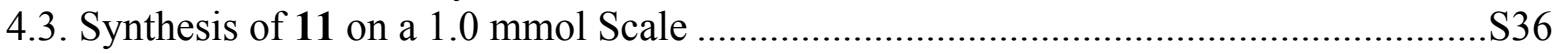

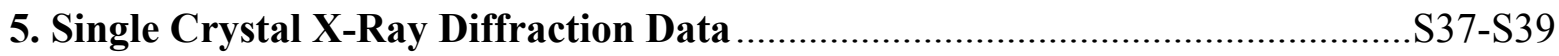

5.1. Crystal Growth and Refinement Procedure …………...............................................S37

5.2. Crystal Data and Structure Refinement Details ……………......................................S38

5.3. Thermal Ellipsoid Plot …………………………….....................................................

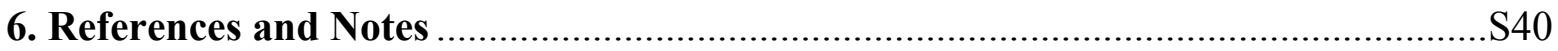

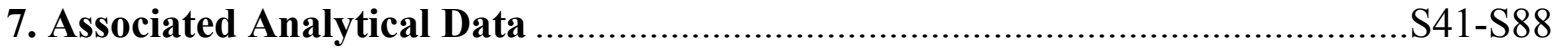

7.1. NMR Spectra of Products and Starting Materials.............................................S41-S70

7.2. Chiral SFC and HPLC Traces of Allylation Products ..........................................S71-S88 


\section{General Experimental Details}

General Experimental Procedures: All reactions were performed in flame-dried or oven-dried glassware fitted with rubber or PTFE/silicone septa under a positive pressure of nitrogen, unless otherwise noted. Standard reactions were performed in glass culture tubes with threaded ends (Fisherbrand, 13×100 mm, 1495935C) that were sealed with screw-thread caps (Kimble Chase Open Top S/T Closure, catalog no. 73804-15425) fitted with PTFE/SIL septa (Thermo Scientific, catalog no. B7995-15). Air- and moisture-sensitive liquids were transferred via syringe or stainless steel cannula. Solids were added under inert gas counter flow or were dissolved in the appropriate solvent. Reactions carried out at temperatures above room temperature (rt) were conducted in a pre-heated oil bath. All reactions were magnetically stirred and monitored by ${ }^{1} \mathrm{H}$ NMR spectroscopy or analytical thin-layer chromatography (TLC), using glass-backed plates pre-coated with silica gel $(250 \mu \mathrm{m}, 60-\AA$ A pore size, Extra Hard Layer, SiliaPlate $)$ impregnated with a fluorescent indicator $(254 \mathrm{~nm})$. TLC plates were visualized by exposure to ultraviolet light (UV), or were stained by submersion in iodine dispersed in sand $\left(\mathrm{I}_{2}\right)$, an acidic solution of cerium ammonium molybdate (CAM) or in aqueous potassium permanganate solution $\left(\mathrm{KMnO}_{4}\right)$ and were developed by heating with a heat gun. Flash column chromatography was performed using SiliCycle SiliaFlash ${ }^{\circledR}$ F60 silica gel (40-63 $\mu$ m, 230-400 mesh, 60 A pore diameter) or with the aid of a Biotage Isolera or a Teledyne ISCO CombiFlash Automated Flash Chromatography System using prepacked SNAP silica cartridges (10-100 g).

Materials: Unless noted otherwise, all reagents and starting materials were purchased from commercial sources and used as received (Millipore-Sigma, Alfa Aesar, Strem, TCI-America, Combi-Blocks, or Matrix Scientific). $\mathrm{CDCl}_{3}$ was purchased from Cambridge Isotope Laboratories. Tetrahydrofuran (THF), diethyl ether $\left(\mathrm{Et}_{2} \mathrm{O}\right)$, toluene $(\mathrm{PhMe})$ and dichloromethane $\left(\mathrm{CH}_{2} \mathrm{Cl}_{2}\right)$ were obtained from J.T. Baker in CYCLE-TAINER ${ }^{\circledR}$ delivery kegs and purified by successive filtrations though packed columns of neutral alumina and $\mathrm{CuO}$ under argon pressure. Dimethylformamide (DMF) and dimethylsulfoxide (DMSO) were purchased from MilliporeSigma in SureSeal ${ }^{\mathrm{TM}}$ bottles and were purged with nitrogen before use. Solvents for extraction, crystallization and flash column chromatography were purchased in A.C.S. reagent grade from Millipore-Sigma, with the exception of hexane and ethyl acetate, which were purchased in HPLC grade. The yields refer to chromatographically and spectroscopically $\left({ }^{1} \mathrm{H}\right.$ and $\left.{ }^{13} \mathrm{C} N \mathrm{NMR}\right)$ pure material.

Caution: Dimethoxy(methyl)silane (DMMS, CAS \#16881-77-9) is listed by several vendors (TCI, Alfa Aesar) SDS or MSDS as H318, category 1 Causes Serious Eye Damage. Other vendors (Millipore-Sigma, Gelest) list DMMS as H319, category II Eye Irritant. DMMS should be handled in a well-ventilated fumehood using proper precaution as outlined for the handling of hazardous materials in: Prudent Practices in the Laboratory. ${ }^{1}$ At the end of the reaction, saturated ammonium fluoride $\left(\mathrm{NH}_{4} \mathrm{~F}\right)$ in methanol $(\mathrm{MeOH})$ should be carefully added to the reaction mixture as described in the detailed reaction procedure.

Instrumentation: NMR spectra were measured on Bruker Avance III HD 400 and $500 \mathrm{MHz}$ spectrometers. Proton chemical shifts are expressed in parts per million (ppm, $\delta$ scale) and are referenced to the residual proton in the NMR solvent $\left(\mathrm{CDCl}_{3}: \delta 7.26\right)$. ${ }^{1} \mathrm{H} \mathrm{NMR}$ spectroscopic data are reported as follows: Chemical shift in ppm (multiplicity, coupling constants $J(\mathrm{~Hz})$, integration intensity, assigned proton). The multiplicities are abbreviated with s (singlet), br s 
(broad singlet), d (doublet), t (triplet), q (quartet), hept (heptet) m (multiplet), a (apparent). All ${ }^{13} \mathrm{C}$ spectra recorded are proton-decoupled. The carbon chemical shifts are expressed in parts per million (ppm, $\delta$ scale) and are referenced to the carbon resonance of the NMR solvent $\left(\mathrm{CDCl}_{3}: \delta\right.$ 77.16). ${ }^{13} \mathrm{C}$ NMR spectroscopic data are reported as follows: Chemical shift in ppm (multiplicity, coupling constants $J(\mathrm{~Hz})$, assigned carbon). All ${ }^{19} \mathrm{~F}$ and ${ }^{31} \mathrm{P}$ chemical shifts are expressed in parts per million (ppm, $\delta$ scale). All raw fid files were processed and the spectra analyzed using the program MestReNOVA 14.2 from Mestrelab Research S. L. High-resolution mass spectra were recorded on a JEOL AccuTOF LC-Plus 46 DART system and on an Agilent Technologies 6545 Q-TOF LC/MS system or JEOL AccuTOF 4G with an ionSense DART. IR spectra were recorded on a Nicolet iS5 spectrometer equipped with an iD5 diamond laminate ATR accessory from Thermo Scientific. IR spectra were acquired from neat samples. If required, substances were dissolved in $\mathrm{CH}_{2} \mathrm{Cl}_{2}$ prior to direct application on the ATR unit. Data are reported as follows: frequency of absorption $\left(\mathrm{cm}^{-1}\right)$. Melting points were determined on an EZ-Melt capillary melting point apparatus from SRS Stanford Research System. The values are uncorrected. Elemental analyses were performed by Atlantic Microlabs Inc., Norcross, GA, USA. Specific optical rotations were recorded for chloroform solutions using a Jasco 1010 polarimeter operating at 589 $\mathrm{nm}$ and $23^{\circ} \mathrm{C}$. Enantiomeric ratio (er) was determined either by chiral HPLC analysis using Agilent 1200 Series chromatographs or by Chiral SFC using a Waters Acquity UPC2 instrument; specific columns and analytic methods are provided in the experimental details for individual compounds. 


\section{Reaction Optimization}

\subsection{Screening of Solvent/Ligands/Silane}

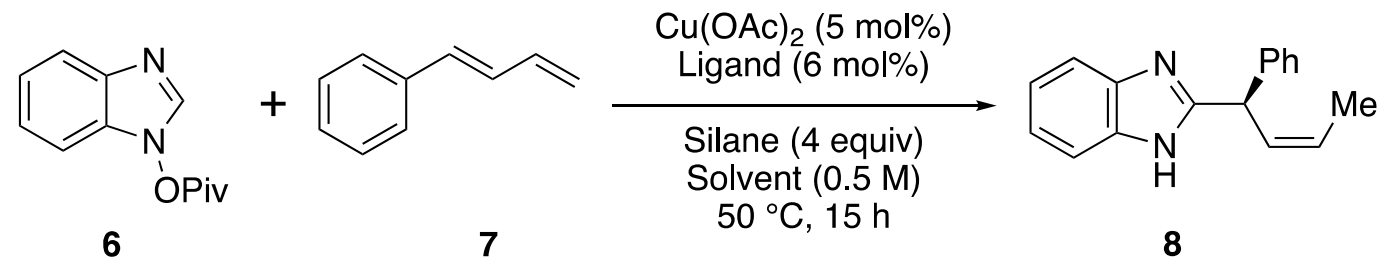

Inside a nitrogen filled glovebox, an oven-dried reaction tube, (tube A), (Fisherbrand, $13 \times 100 \mathrm{~mm}, 1495935 \mathrm{C})$ equipped with a magnetic stir bar was charged with $\mathrm{Cu}(\mathrm{OAc})_{2}(1.4 \mathrm{mg}$, $7.5 \mu \mathrm{M}, 5 \mathrm{~mol} \%)$, ligand $(9.0 \mu \mathrm{mol}, 6 \mathrm{~mol} \%)$ and solvent $(0.3 \mathrm{~mL})$. This solution was then capped with a screw cap fitted with a PTFE septum and allowed to stir for $10 \mathrm{~min}$ before the silane $(0.60$ mmol, 4.0 equiv) was added to tube $\mathbf{A}$ via pipette. The mixture was subsequently allowed to stir for $15 \mathrm{~min}$.

Separately, another oven-dried reaction tube, (tube B) (Fisherbrand, 13x100 mm, 1495935C) equipped with a magnetic stir bar, was charged with $N$-OPiv benzimidazole (6) (32.7 mg, $0.150 \mathrm{mmol}, 1$ equiv) and 1-phenyl- $E$-butadiene (7) $(42.1 \mu \mathrm{L}, 0.300 \mathrm{mmol}, 2$ equiv).

The copper hydride solution in tube $\mathbf{A}(0.375 \mathrm{~mL})$ was added to reaction tube $\mathbf{B}$ with aid of a syringe. Reaction tube $\mathbf{B}$ was then capped with a screw cap fitted with a PTFE septum, removed from the glovebox, and placed in an oil bath preheated to $50^{\circ} \mathrm{C}$.

After the reaction mixture was stirred for $15 \mathrm{~h}$ at $50{ }^{\circ} \mathrm{C}$, the reaction tube was removed from the oil bath and was allowed to cool to rt, at which time the cap was removed and a sat. solution of $\mathrm{NH}_{4} \mathrm{~F}$ in $\mathrm{MeOH}(1 \mathrm{~mL})$ was added and allowed to stir $5 \mathrm{~min}$. At this time, a sat. aq. solution of $\mathrm{NaHCO}_{3}(2 \mathrm{~mL})$ was added. The crude reaction mixture was extracted with EtOAc $(3 \times 3 \mathrm{~mL})$ and the combined organic phases were filtered through a glass pipette (Kimble, 5-3/4" Glass Monster Pipette) containing a $5 \mathrm{~cm}$ plug of $\mathrm{MgSO}_{4}$, transferred to a 5 dram vial, then concentrated in vacuo with the aid of a rotary evaporator.

The crude oil was dissolved in $\mathrm{CDCl}_{3}(2 \mathrm{~mL})$ and an internal standard, 1,1,2,2tetrachloroethane $(10.0 \mu \mathrm{L}, 15.9 \mathrm{mg}, 0.0947 \mathrm{mmol})$ was added using a glass airtight syringe. The yield of the reaction was determined by ${ }^{1} \mathrm{H}$ NMR. Then, the crude material was purified using a pipette column of silica (a 5-3/4" Glass Monster Pipette was plugged with a small piece of cotton and filled with $5 \mathrm{~cm}$ of silica gel, then basified by rinsing with a solution of 49:50:1 EtOAc:hexane:Et $\left.{ }_{3} \mathrm{~N}\right)$. The column was eluted with 49:50:1 EtOAc:hexane:Et ${ }_{3} \mathrm{~N}(5 \mathrm{~mL})$ and the collected material was concentrated in vacuo with the aid of a rotary evaporator. The resultant product was evaluated by chiral SFC or chiral HPLC to determine the enantioselectivity of the reaction. 
Supporting Information

Table S1:

Silane $(4$ equiv)
Solvent $(0.5 \mathrm{M})$
$50{ }^{\circ} \mathrm{C}, 15 \mathrm{~h}$

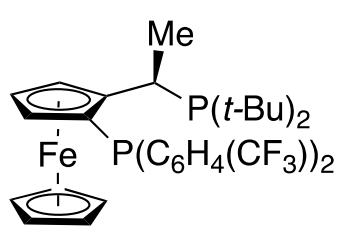

L1

JosiPhos SL-J011-1<smiles>CP(c1nc2ccccc2nc1P(C)C(C)(C)C)C(C)(C)C</smiles>

L2

$(R, R)$-QuinoxP*<smiles>CCCCCc1ccc2c(c1-c1c(P)ccc3c1OCO3)OCO2</smiles>

L3

(R)-DTBM-SEGPHOS $\mathrm{Ar}=3,5-(t-\mathrm{Bu})-4-\mathrm{MeOC}_{6} \mathrm{H}_{2}$<smiles>c1ccc(C2CC[C@H](c3ccccc3)P2CCP2[C@H](c3ccccc3)CC[C@H]2c2ccccc2)cc1</smiles>

L4 $(S, S)-\mathrm{Ph}-\mathrm{BPE}$ 


\subsection{Effect of Olefin Geometry:}

Following the screening procedure described above (Section 2.1), dienes as both pure $E$ isomers, and mixtures of $E / Z$ isomers were subjected to the reaction conditions. It was found that the use of $E$-dienes was necessary in order to obtain the products with good e.r., as dienes used as an $E / Z$ mixture gave poor e.r. Additionally, it was found that the allylation products isolated were almost exclusively the $Z$-isomer $(<1: 20 E: Z)$, regardless of the geometry of the starting diene. The results are summarized in Scheme S1.

\section{Scheme S1:}
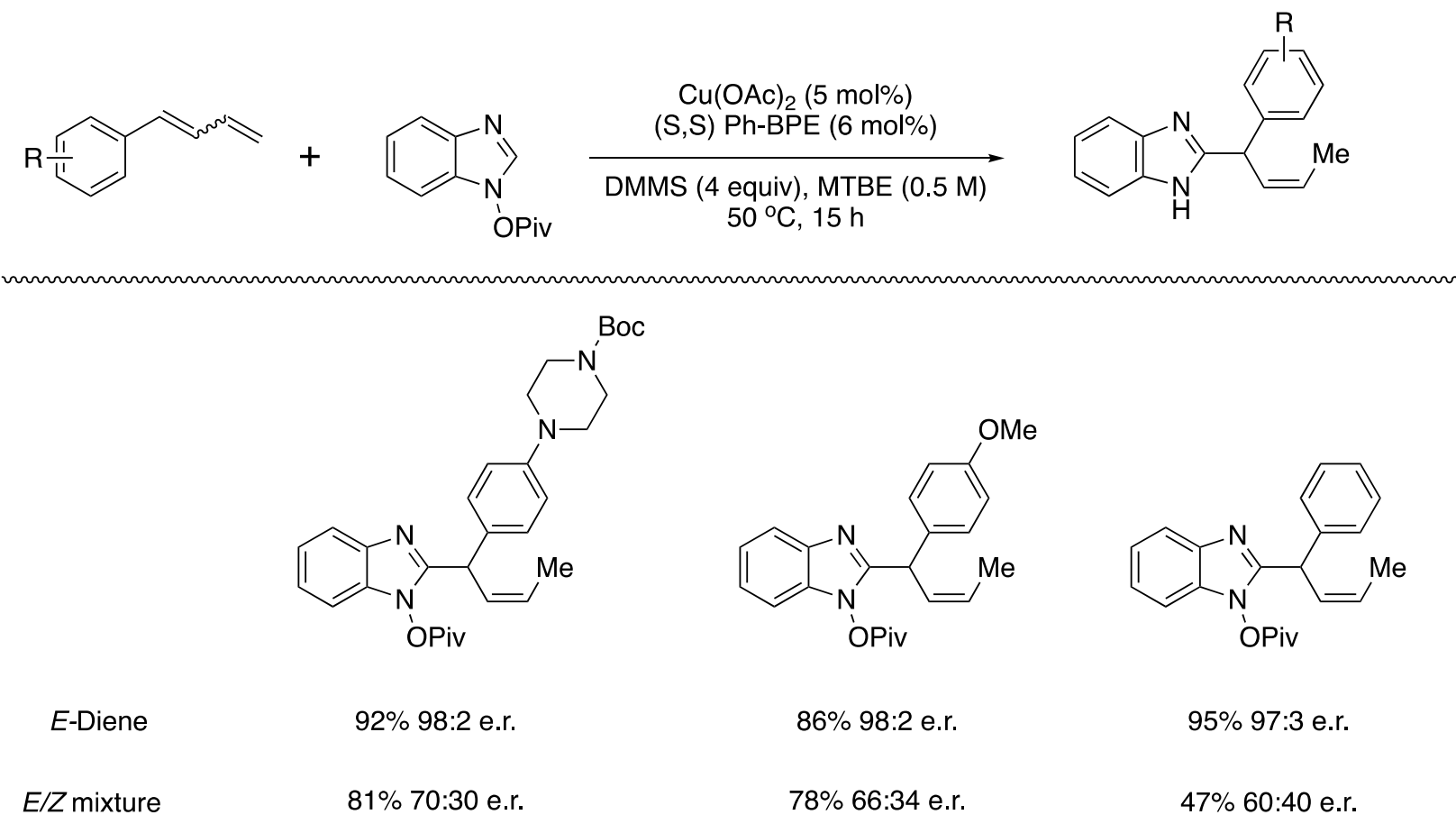


\subsection{Study on Racemization of 8 .}

Initially, it was found that the measured enantiomeric ratio (e.r.) of the isolated product $\mathbf{8}$ was inconsistent. To ascertain the origin of this phenomenon, a series of purification conditions were evaluated, and it was found that treating the silica with $\mathrm{Et}_{3} \mathrm{~N}$ and utilizing $\mathrm{Et}_{3} \mathrm{~N}$ as a cosolvent in the eluent during chromatography resulted in reproducibly high e.r. (Table S2). Based on these results, we believe that silica was protonating the benzimidazole product at N3, facilitating subsequent deprotonation at the benzylic position, resulting in racemization of the product. We found more evidence for this hypothesis after stirring the isolated product (8) with silica in isopropyl alcohol $(i-\mathrm{PrOH})$, observing an erosion of the e.r. There was no erosion of the e.r. observed when storing $\mathbf{8}$ in 100\% isopropyl alcohol for several days.

\section{Table S2:}<smiles>C/C=C\[C@H](c1ccccc1)c1nc2ccccc2[nH]1</smiles>
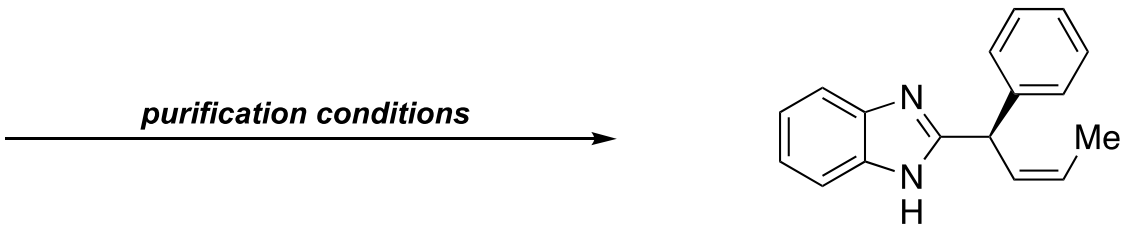

$\begin{array}{cccc}\begin{array}{c}\text { crude reaction } \\ \text { mixture }\end{array} & \text { entry } & \text { purification conditions } & \text { er } \\ & \mathbf{1} & \text { silica gel chromatography } & 85: 15 \\ 98: 2 \text { e.r. } & \mathbf{2} & \mathrm{Et}_{3} \mathrm{~N} \text { Treated Silica } & 93: 7 \\ & \mathbf{3} & \text { basic alumina } & 92: 8 \\ & \mathbf{4} & \text { Florisil } & 92: 8 \\ & \mathbf{5} & \mathrm{Et}_{3} \mathrm{~N} \text { treated silica with } 1 \% \mathrm{Et}_{3} \mathrm{~N} \text { in eluent } & 98: 2\end{array}$

Scheme S2: Racemization studies on Pure 8<smiles>C/C=C\[C@H](c1ccccc1)c1nc2ccccc2[nH]1</smiles><smiles>C/C=C\[C@H](c1ccccc1)c1nc2ccccc2[nH]1</smiles>

Pure 8 90:10 e.r.

77:23 e.r. 
Supporting Information

3. Synthesis and Characterization of Starting Materials<smiles>[TeH4]On1cnc2ccccc21</smiles>

6

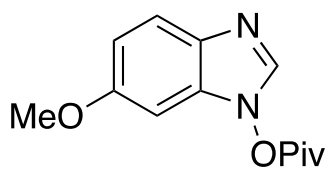

S3<smiles>C=CC=Cc1ccccc1</smiles>

7<smiles>C=C/C=C/c1ccc(C(F)(F)F)cc1</smiles>

S8<smiles>C=C/C=C/c1ccc2c(ccn2[As])c1</smiles><smiles>C=CC(=C)c1cn(C(=O)OC(C)(C)C)c2ccccc12</smiles>

S14<smiles>[Mg]On1cnc2cc(Br)ccc21</smiles>

S1<smiles>[Mg]On1cnc2ccc(Cl)cc21</smiles>

S4<smiles>C=C/C=C(\C)c1ccccc1</smiles>

S6<smiles>C=C/C=C/c1ccc(OC)cc1</smiles>

S9<smiles>C=CC(=C)c1ccccc1</smiles>

$\mathrm{S} 12$<smiles>C=CC(=C)c1ccc(Cl)cc1</smiles>

S15

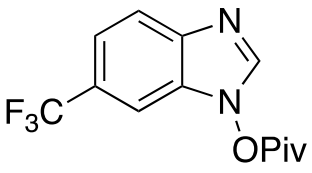

S2<smiles>CCOn1cnc2ccc(-c3cccs3)cc21</smiles>

S5<smiles>C=C/C=C/c1cccc(Br)c1</smiles>

S7<smiles>C=CC=Cc1ccc(N2CCN(C(=O)OC(C)(C)C)CC2)cc1</smiles>

S10<smiles>C=CC(=C)c1ccc(OC)cc1</smiles>

S13 


\subsection{Synthesis and Characterization of $N$-OPiv Benzimidazoles}

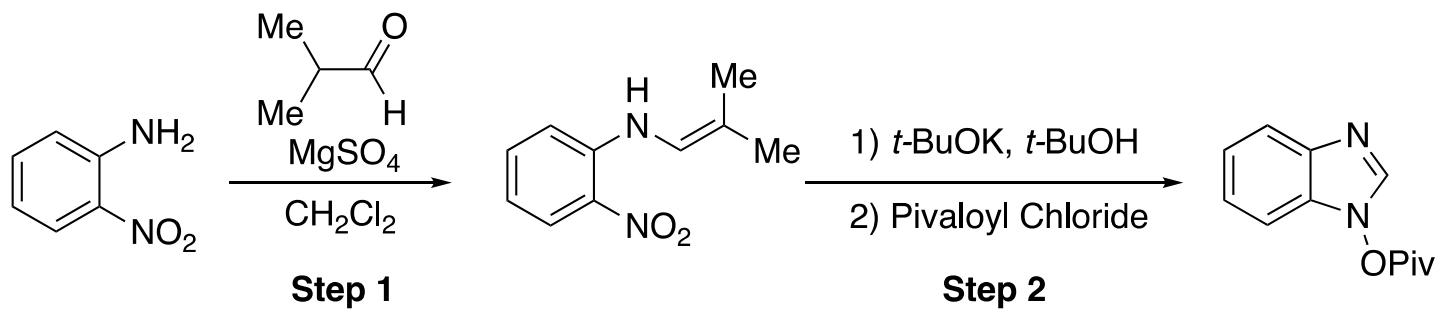

\section{General Procedure A: for the synthesis of $\mathrm{N}$-OPiv benzimidazoles. ${ }^{2}$}

Step 1: An oven-dried $300 \mathrm{~mL}$ round-bottom flask equipped with a magnetic stir bar was charged with $\mathrm{MgSO}_{4}(50.0 \mathrm{~g}, 0.420 \mathrm{~mol}, 5.7$ equiv) and nitroaniline ( $72.0 \mathrm{mmol}, 1.0$ equiv). The flask was fitted with a reflux condenser, sealed with a rubber septum and attached by rubber hose via a needle to a dual manifold Schlenk line. The flask was evacuated and backfilled with nitrogen (this process was repeated a total of three times). $\mathrm{CH}_{2} \mathrm{Cl}_{2}(150 \mathrm{~mL}$ ) was added, followed by isobutyraldehyde ( $26.0 \mathrm{~mL}, 0.290 \mathrm{~mol}, 4$ equiv), then the flask was placed in an oil bath and the reaction solution was heated to reflux.

After $5 \mathrm{~d}$, the reaction flask was removed from the oil bath and allowed to cool to rt. The reaction mixture was then filtered through a glass frit into a $500 \mathrm{~mL}$ round-bottom flask. The filter cake was washed with $\mathrm{CH}_{2} \mathrm{Cl}_{2}(100 \mathrm{~mL})$ and the filtrate was concentrated in vacuo with the aid of a rotary evaporator.

Step 2: A $500 \mathrm{~mL}$ round-bottom flask equipped with a magnetic stir bar was charged with the enamine from step 1 (27.5 mmol, 1.0 equiv). Next, tert-butanol $(t-\mathrm{BuOH})(200 \mathrm{~mL})$ was added, followed by potassium tert-butoxide ( $t$-BuOK) $(12.4 \mathrm{~g}, 110.0 \mathrm{mmol}, 4.0$ equiv). The flask was sealed with a rubber septum and attached to a dual manifold Schlenk line by rubber hose via a needle. The rubber septum was pierced with an outlet needle, and the flask was purged with nitrogen for $10 \mathrm{~min}$. The outlet needle was then removed, and the flask allowed to stir at rt.

After the reaction mixture had stirred for $15 \mathrm{~h}$, the flask was placed in a rt water bath, and pivaloyl chloride (10.2 mL, $82.7 \mathrm{mmol}, 3.0$ equiv) was added dropwise via syringe (by puncturing the rubber septum). The flask was removed from the water bath and the reaction mixture was allowed to stir at $\mathrm{rt}$ for an additional $6 \mathrm{~h}$. At this point, the reaction was quenched by the addition of sat. aq. $\mathrm{NaHCO}_{3}$ solution $(150 \mathrm{~mL})$, and the contents of the flask were transferred to a separatory funnel and then extracted with $\mathrm{Et}_{2} \mathrm{O}(3 \times 150 \mathrm{~mL})$. The combined organic extracts were dried over $\mathrm{Na}_{2} \mathrm{SO}_{4}$, filtered, then concentrated in vacuo with the aid of a rotary evaporator to obtain the crude solid. This material was purified by flash chromatography and if necessary, a subsequent recrystallization to give the $\mathrm{N}$-OPiv benzimidazole.

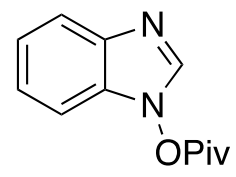

\section{$1 H$-benzimidazol-1-yl pivalate (6)}

Step 1: Prepared according to General Procedure A, with $\mathrm{MgSO}_{4}(50.0 \mathrm{~g}, 0.420 \mathrm{~mol}, 5.7$ equiv) and 2-nitroaniline (10.0 g, $72.0 \mathrm{mmol}, 1.0$ equiv), $\mathrm{CH}_{2} \mathrm{Cl}_{2}(150 \mathrm{~mL})$ and isobutyraldehyde (26.0 mL, $0.290 \mathrm{~mol}, 4$ equiv). The resultant material was dried under high vacuum for $24 \mathrm{~h}$ to 
give a dark-purple solid (11.7 g, 84\% yield). The crude product was used in the subsequent step without further purification.

$N$-(2-methylprop-1-en-1-yl)-2-nitroaniline

${ }^{1}$ H NMR $\left(\mathrm{CDCl}_{3}, 400 \mathrm{MHz}\right): \delta 9.72-9.45(\mathrm{~m}, 1 \mathrm{H}), 8.17(\mathrm{dd}, J=8.7,1.6 \mathrm{~Hz}, 1 \mathrm{H}), 7.43$ (ddd, $J=$ 8.6, 6.8, $1.6 \mathrm{~Hz}, 1 \mathrm{H}), 7.04(\mathrm{dd}, J=8.7,1.2 \mathrm{~Hz}, 1 \mathrm{H}), 6.70(\mathrm{ddd}, J=8.5,6.9,1.3 \mathrm{~Hz}, 1 \mathrm{H}), 6.27$ (dt, $J=9.6,1.5 \mathrm{~Hz}, 1 \mathrm{H}), 1.81(\mathrm{dd}, J=10.4,1.4 \mathrm{~Hz}, 6 \mathrm{H})$.

Step 2: Prepared according to General Procedure A with $N$-(2-methylprop-1-en-1-yl)-2nitroaniline (5.30 g, $27.5 \mathrm{mmol}, 1.0$ equiv), $t$-BuOH (200 mL), $t$-BuOK (12.4 g, $110 \mathrm{mmol}, 4.0$ equiv), and pivaloyl chloride (10.2 mL, $82.7 \mathrm{mmol}, 3.0$ equiv). The crude material was purified by flash chromatography (50 g silica, gradient elution, hexane to 5:95 EtOAc:hexane) to obtain a light brown solid (3.16 g, 53\% yield). This material was further purified through recrystallization by dissolving with $25 \mathrm{~mL}$ of refluxing 10:90 EtOAc:hexane, then cooling in a $-5{ }^{\circ} \mathrm{C}$ freezer to give 6 as colorless needles $(2.42 \mathrm{~g}, 40 \%$ yield $)$.

${ }^{1} \mathbf{H}$ NMR $\left(\mathrm{CDCl}_{3}, 400 \mathrm{MHz}\right): \delta 7.92(\mathrm{~s}, 1 \mathrm{H}), 7.81-7.79(\mathrm{~m}, 1 \mathrm{H}), 7.31(\mathrm{tt}, J=7.4,5.7 \mathrm{~Hz}, 2 \mathrm{H})$, $7.22(\mathrm{dd}, J=7.7,1.6 \mathrm{~Hz}, 1 \mathrm{H}), 1.47(\mathrm{~s}, 9 \mathrm{H})$.

${ }^{13}$ C NMR $\left(\mathrm{CDCl}_{3}, 126 \mathrm{MHz}\right): \delta 175.3,139.3,138.5,130.4,124.3,123.0,121.1,108.1,38.8$, 27.2.

IR (Diamond-ATR, neat, $\mathrm{cm}^{-1}$ ) $\tilde{v}_{\max }: 3126,2982,1797,1477,1446,1371,1319,1227,1052$, 1019, 851, 781, 733 .

Melting Point $\left({ }^{\circ} \mathrm{C}\right): 85-87$.

HRMS (DART) m/z [M+H] $]^{+}$calcd. for $\mathrm{C}_{12} \mathrm{H}_{15} \mathrm{~N}_{2} \mathrm{O}_{2}$ : 219.1128; Found: 219.1129.<smiles>POn1cnc2cc(Br)ccc21</smiles>

\section{5-Bromo-1H-benzimidazol-1-yl pivalate (S1)}

Step 1: Prepared according to General Procedure A with $\mathrm{MgSO}_{4}(8.0 \mathrm{~g}, 66 \mathrm{mmol}, 5.0$ equiv), 3-bromo-6-nitroaniline (3.00 g, $13.8 \mathrm{mmol}, 1.0$ equiv), $\mathrm{CH}_{2} \mathrm{Cl}_{2}$ (100 mL), and isobutyraldehyde $(5.05 \mathrm{~mL}, 55.3 \mathrm{mmol}, 4$ equiv). The resultant material was dried under high vacuum for $24 \mathrm{~h}$ to give an orange solid ( $2.48 \mathrm{~g}, 66 \%$ yield). The crude product was used in the subsequent step without further purification.

3-bromo- $N$-(2-methylprop-1-en-1-yl)-6-nitroaniline

${ }^{1} \mathbf{H}$ NMR $\left(\mathrm{CDCl}_{3}, 400 \mathrm{MHz}\right): \delta 9.56(\mathrm{~d}, J=8.5 \mathrm{~Hz}, 1 \mathrm{H}), 8.04(\mathrm{~d}, J=9.1 \mathrm{~Hz}, 1 \mathrm{H}), 7.20(\mathrm{~d}, J=2.0$ $\mathrm{Hz}, 1 \mathrm{H}), 6.81(\mathrm{dd}, J=9.2,2.0 \mathrm{~Hz}, 1 \mathrm{H}), 6.19(\mathrm{dp}, J=9.3,1.5 \mathrm{~Hz}, 1 \mathrm{H}), 1.97-1.72(\mathrm{~m}, 6 \mathrm{H})$.

Step 2: Prepared according to General Procedure A with 3-bromo- $N$-(2-methylprop-1en-1-yl)-6-nitroaniline (2.40 g, $8.85 \mathrm{mmol}, 1.0$ equiv), $t$-BuOH (200 mL) $t$-BuOK (3.97 g 35.4 mmol, 4.0 equiv) and pivaloyl chloride $(5.45 \mathrm{~mL}, 44.3 \mathrm{mmol}, 5.0$ equiv). The crude material was 
purified by flash chromatography (50 g silica, gradient elution, hexane to 40:60 EtOAc:hexane) to obtain a light brown solid. This material was further purified through recrystallization by dissolving with $10 \mathrm{~mL}$ of refluxing 20:80 EtOAc:hexane, then cooling in a $-5^{\circ} \mathrm{C}$ freezer to give $\mathrm{S} 1$ as colorless cubic crystals $(1.1 \mathrm{~g}, 42 \%$ yield $)$.

${ }^{1} \mathbf{H}$ NMR $\left(\mathrm{CDCl}_{3}, 400 \mathrm{MHz}\right): \delta 7.94(\mathrm{~d}, J=1.8 \mathrm{~Hz}, 1 \mathrm{H}), 7.90(\mathrm{~s}, 1 \mathrm{H}), 7.42(\mathrm{dd}, J=8.6,1.8 \mathrm{~Hz}$, $1 \mathrm{H}), 7.08(\mathrm{~d}, J=8.6 \mathrm{~Hz}, 1 \mathrm{H}), 1.47(\mathrm{~s}, 9 \mathrm{H})$.

${ }^{13} \mathrm{C} \mathrm{NMR}\left(\mathrm{CDCl}_{3}, 126 \mathrm{MHz}\right): \delta 175.1,140.6,139.5,129.5,127.5,124.1,116.1,109.5,38.9$, 27.2.

IR (Diamond-ATR, neat, $\mathrm{cm}^{-1}$ ) $\tilde{v}_{\max }: 3121,2978,1792,1574,1478,1451,1220,1058,1020$, $891,849,806,616$.

Melting Point $\left({ }^{\circ} \mathrm{C}\right): 109-110$.

HRMS (DART) m/z [M+H] $]^{+}$calcd. for $\mathrm{C}_{12} \mathrm{H}_{14} \mathrm{BrN}_{2} \mathrm{O}_{2}$ : 297.0233; Found: 297.0232.<smiles>COn1cnc2ccc(C(F)(F)F)cc21</smiles>

\section{6-(Trifluoromethyl)-1H-benzimidazol-1-yl pivalate (S2)}

Step 1: Prepared according to General Procedure A with $\mathrm{MgSO}_{4}(16 \mathrm{~g}, 0.13 \mathrm{~mol}, 6.8$ equiv), 2-nitro-4-(trifluoromethyl)aniline (4.00 g, $19.3 \mathrm{mmol}, 1.0$ equiv), $\mathrm{CH}_{2} \mathrm{Cl}_{2}(200 \mathrm{~mL}$ ) and isobutyraldehyde $(7.1 \mathrm{~mL}, 77.63 \mathrm{mmol}, 4$ equiv). The resultant material was dried under high vacuum for $24 \mathrm{~h}$ to give a dark-purple solid ( $3.2 \mathrm{~g}, 63 \%$ yield). The crude product was used in the subsequent step without further purification.

$N$-(2-methylprop-1-en-1-yl)-2-nitro-4-(trifluoromethyl)aniline

${ }^{1}$ H NMR $\left(\mathrm{CDCl}_{3}, 400 \mathrm{MHz}\right): \delta 9.77(\mathrm{~s}, 1 \mathrm{H}), 8.48(\mathrm{dd}, J=2.3,1.0 \mathrm{~Hz}, 1 \mathrm{H}), 7.61$ (dd, $J=9.1,2.2$ $\mathrm{Hz}, 1 \mathrm{H}), 7.12(\mathrm{~d}, J=9.1 \mathrm{~Hz}, 1 \mathrm{H}), 6.26(\mathrm{dt}, J=9.3,1.5 \mathrm{~Hz}, 1 \mathrm{H}), 1.95-1.77(\mathrm{~m}, 6 \mathrm{H})$.

Step 2: Prepared according to General Procedure A with N-(2-methylprop-1-en-1-yl)-2nitro-4-(trifluoromethyl)aniline (3.2 g, $12.3 \mathrm{mmol}, 1.0$ equiv), $t$-BuOH (200 mL), $t$-BuOK (5.52 g, $49.19 \mathrm{mmol}, 4.0$ equiv) and pivaloyl chloride ( $4.54 \mathrm{~mL}, 36.9 \mathrm{mmol}, 3.0$ equiv). The crude material was purified by flash chromatography (50 g silica, gradient elution, hexane to 20:80 EtOAc:hexane) to obtain $\mathbf{S 2}$ as a light brown solid (1.90 g, 54\% yield).

${ }^{1} \mathbf{H}$ NMR $\left(\mathrm{CDCl}_{3}, 500 \mathrm{MHz}\right): \delta 8.05(\mathrm{~s}, 1 \mathrm{H}), 7.90(\mathrm{~d}, J=8.5 \mathrm{~Hz}, 1 \mathrm{H}), 7.57(\mathrm{dd}, J=8.6,1.7 \mathrm{~Hz}$, $1 \mathrm{H}), 7.48(\mathrm{~s}, 1 \mathrm{H}), 1.51(\mathrm{~s}, 9 \mathrm{H})$.

${ }^{13} \mathrm{C} \mathrm{NMR}\left(\mathrm{CDCl}_{3}, 126 \mathrm{MHz}\right): \delta 175.1,141.4,140.8,129.9,126.7(\mathrm{q}, J=32.6 \mathrm{~Hz}), 124.5(\mathrm{q}, J=$ $236.9 \mathrm{~Hz}), 121.8,120.1$ (q, $J=3.6 \mathrm{~Hz}), 106.2$ (q, $J=4.3 \mathrm{~Hz}), 39.0,27.2$.

${ }^{19}$ F NMR $\left(\mathrm{CDCl}_{3} 471 \mathrm{MHz}\right): \delta-61.02$. 
IR (Diamond-ATR, neat, $\mathrm{cm}^{-1}$ ) $\tilde{v}_{\max }: 3122,2986,1795,1484,1466,1449,1329,1277,1224$, $1153,1116,1085,910,866,746,662$.

Melting Point $\left({ }^{\circ} \mathrm{C}\right): 107-108$.

HRMS (DART) m/z [M+H] calcd. for $\mathrm{C}_{13} \mathrm{H}_{14} \mathrm{~F}_{3} \mathrm{~N}_{2} \mathrm{O}_{2}$ : 287.1002; Found: 287.1009.<smiles>COc1ccc2ncn(OC#N)c2c1</smiles>

\section{6-methoxy-1H-benzimidazol-1-yl pivalate (S3)}

Step 1: Prepared according to General Procedure A with $\mathrm{MgSO}_{4}(12.5 \mathrm{~g}, 104 \mathrm{mmol}, 5$ equiv), 4-methoxy-2-nitroaniline (3.50 g, $20.8 \mathrm{mmol}, 1.0$ equiv), $\mathrm{CH}_{2} \mathrm{Cl}_{2}$ (100 mL) and isobutyraldehyde $(7.60 \mathrm{~mL}, 83.3 \mathrm{mmol}, 4$ equiv $)$. The resultant material was dried under high vacuum for $24 \mathrm{~h}$ to give a dark-red, waxy, low-melting solid (4.90 g, quantitative yield). The crude product was used in the subsequent step without further purification.

6-methoxy- $N$-(2-methylprop-1-en-1-yl)-2-nitroaniline

${ }^{1} \mathbf{H}$ NMR $\left(\mathrm{CDCl}_{3}, 400 \mathrm{MHz}\right): \delta 9.58(\mathrm{~d}, J=9.7 \mathrm{~Hz}, 1 \mathrm{H}), 7.60(\mathrm{~d}, J=3.0 \mathrm{~Hz}, 1 \mathrm{H}), 7.15(\mathrm{dd}, J=$ 9.4, 3.1 Hz, 1H), $7.02(\mathrm{~d}, J=9.4 \mathrm{~Hz}, 1 \mathrm{H}), 6.26(\mathrm{dt}, J=9.7,1.5 \mathrm{~Hz}, 1 \mathrm{H}), 3.80(\mathrm{~s}, 3 \mathrm{H}), 1.80(\mathrm{dd}, J$ $=7.8,1.4 \mathrm{~Hz}, 6 \mathrm{H})$.

Step 2: Prepared according to General Procedure A with 6-methoxy- $N$-(2-methylprop-1en-1-yl)-2-nitroaniline (4.90 g, $22 \mathrm{mmol}, 1.0$ equiv) $t$ - $\mathrm{BuOH}(150 \mathrm{~mL}), t$-BuOK $(10 \mathrm{~g}, 89 \mathrm{mmol}$, 4.0 equiv), and pivaloyl chloride ( $14 \mathrm{~mL}, 110 \mathrm{mmol}, 5.0$ equiv). The crude material was purified by flash chromatography (50 g silica, gradient elution, hexane to 20:80 EtOAc:hexane) to obtain $\mathbf{S 3}$ as a viscous brown oil (3.1 $\mathrm{g}, 57 \%$ yield).

${ }^{1} \mathbf{H}$ NMR $\left(\mathrm{CDCl}_{3}, 500 \mathrm{MHz}\right): \delta 7.82(\mathrm{~s}, 1 \mathrm{H}), 7.64(\mathrm{~d}, J=8.9 \mathrm{~Hz}, 1 \mathrm{H}), 6.89(\mathrm{dd}, J=8.9,2.4 \mathrm{~Hz}$, $1 \mathrm{H}), 6.60(\mathrm{~d}, J=2.4 \mathrm{~Hz}, 1 \mathrm{H}), 3.80(\mathrm{~s}, 3 \mathrm{H}), 1.44$ (s, 9H).

${ }^{13} \mathbf{C ~ N M R}\left(\mathrm{CDCl}_{3}, 126 \mathrm{MHz}\right): \delta 175.2,157.7,137.7,133.5,131.0,121.5,112.1,91.5,55.8,38.7$, 27.1 .

IR (Diamond-ATR, neat, $\mathrm{cm}^{-1}$ ) $\tilde{v}_{\max }: 2971,1798,1702,1632,1497,1454,1357,1240,1215$, 1174, 1052, 1015, 936, 815.

Melting Point $\left({ }^{\circ} \mathrm{C}\right): 23-25$.

HRMS (DART) m/z [M+H] $]^{+}$calcd. for $\mathrm{C}_{13} \mathrm{H}_{17} \mathrm{~N}_{2} \mathrm{O}_{3}$ : 249.1234; Found: 249.1247. 
<smiles>N#COn1cnc2ccc(Cl)cc21</smiles>

\section{6-chloro-1H-benzimidazol-1-yl pivalate (S4)}

Step 1: Prepared according to General Procedure A with $\mathrm{MgSO}_{4}(25 \mathrm{~g}, 208 \mathrm{mmol}, 6$ equiv), 4-chloro-2-nitroaniline (6.00 g, $34.8 \mathrm{mmol}, 1.0$ equiv), $\mathrm{CH}_{2} \mathrm{Cl}_{2}$ (100 mL), and isobutyraldehyde $(12.7 \mathrm{~mL}, 139 \mathrm{mmol}, 4$ equiv). The resultant material was dried under high vacuum for $24 \mathrm{~h}$ to give a dark-red solid $(6.40 \mathrm{~g}, 81 \%$ yield). The crude product was used in the subsequent step without further purification.

6-chloro- $N$-(2-methylprop-1-en-1-yl)-2-nitroaniline

${ }^{1} \mathbf{H}$ NMR $\left(\mathrm{CDCl}_{3}, 400 \mathrm{MHz}\right): \delta 9.56(\mathrm{~s}, 1 \mathrm{H}), 8.18(\mathrm{~d}, J=2.5 \mathrm{~Hz}, 1 \mathrm{H}), 7.38(\mathrm{dd}, J=9.1,2.6 \mathrm{~Hz}$, $1 \mathrm{H}), 7.01(\mathrm{~d}, J=9.2 \mathrm{~Hz}, 1 \mathrm{H}), 6.22(\mathrm{~d}, J=9.5 \mathrm{~Hz}, 1 \mathrm{H}), 1.81$ (d, $J=10.4 \mathrm{~Hz}, 6 \mathrm{H})$.

Step 2: Prepared according to General Procedure A with 6-chloro- $N$-(2-methylprop-1en-1-yl)-2-nitroaniline (6.40 g, $28.0 \mathrm{mmol}, 1.0$ equiv), $t$-BuOH $(200 \mathrm{~mL}), t$-BuOK $(13 \mathrm{~g}, 110$ mmol, 4.0 equiv), and pivaloyl chloride (17.2 mL, $140 \mathrm{mmol}, 5.0$ equiv). The crude material was purified by flash chromatography (50 g silica, gradient elution, hexane to 20:80 EtOAc:hexane) to obtain a brown solid. This material was further purified through recrystallization by dissolving with $10 \mathrm{~mL}$ of refluxing 10:90 EtOAc:hexane, then cooling in a $-5{ }^{\circ} \mathrm{C}$ freezer to obtain $\mathbf{S 4}$ as colorless needles $(2.00 \mathrm{~g}, 28 \%$ yield $)$.

${ }^{1} \mathrm{H}$ NMR $\left(\mathrm{CDCl}_{3}, 400 \mathrm{MHz}\right): \delta 7.90(\mathrm{~s}, 1 \mathrm{H}), 7.70(\mathrm{~d}, J=8.6 \mathrm{~Hz}, 1 \mathrm{H}), 7.26(\mathrm{dd}, J=8.7,2.0 \mathrm{~Hz}$, $1 \mathrm{H}), 7.18(\mathrm{~d}, J=2.0 \mathrm{~Hz}, 1 \mathrm{H}), 1.47(\mathrm{~s}, 9 \mathrm{H})$.

${ }^{13} \mathbf{C ~ N M R}\left(\mathrm{CDCl}_{3}, 101 \mathrm{MHz}\right): \delta 175.1,139.2,137.9,131.0,130.2,123.8,122.1,108.4,38.8$, 27.2.

IR (Diamond-ATR, neat, $\mathrm{cm}^{-1}$ ) $\tilde{v}_{\max }: 3125,2976,1795,1720,1611,1461,1393,1350,1299$, $1273,1057,1017,899,851$.

Melting Point $\left({ }^{\circ} \mathrm{C}\right): 93-95$.

HRMS (DART) m/z [M+H $]^{+}$calcd. for $\mathrm{C}_{12} \mathrm{H}_{14} \mathrm{ClN}_{2} \mathrm{O}_{2}: 253.0738$; Found: 253.0775.

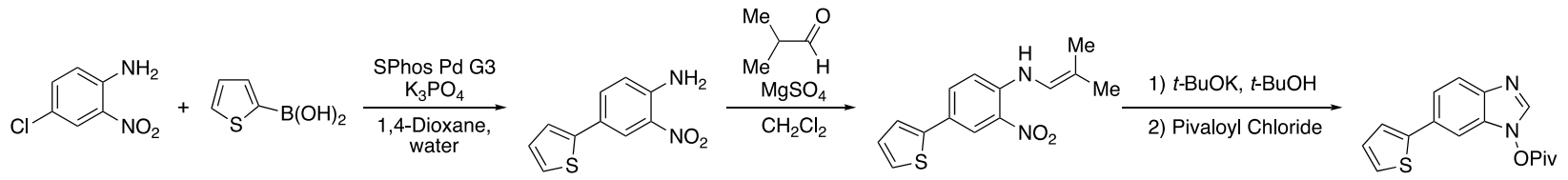

\section{6-(thiophen-2-yl)-1H-benzimidazol-1-yl pivalate (S5)}

An oven-dried $300 \mathrm{~mL}$ round-bottom flask equipped with a magnetic stir bar was charged with SPhos Pd G3 (565 mg, $724 \mu \mathrm{M}, 2.5$ mol\%), $\mathrm{K}_{3} \mathrm{PO}_{4}$ (12.3 g, 57.9 mmol, 2.0 equiv), 4chloro-2-nitroaniline $(5.00 \mathrm{~g}, 29.0 \mathrm{mmol}, 1$ equiv), thiophen-2-ylboronic acid (7.41 g, $57.9 \mathrm{mmol}$, 
2.0 equiv), 1,4-dioxane $(120 \mathrm{~mL})$ and water $(27 \mathrm{~mL})$. The flask was sealed with a rubber septum, attached by rubber hose via a needle to a dual manifold Schlenk line, and evacuated and backfilled with nitrogen (this cycle was repeated a total of three times). The reaction flask was then placed in an oil bath preheated to $50^{\circ} \mathrm{C}$.

After heating the reaction mixture for $20 \mathrm{~h}$, the flask was removed from the oil bath and allowed to cool to rt. The crude reaction mixture was filtered through a short pad $(2 \mathrm{~cm})$ of silica using a fritted funnel. The reaction flask was rinsed with $30 \mathrm{~mL}$ of additional EtOAc, and the rinsate was passed through the filter cake. The solvent was removed in vacuo with the aid of a rotary evaporator and the resultant crude oil was purified by column chromatography $(100 \mathrm{~g}$ silica, gradient elution, hexane to 40:60 EtOAc:hexane) to give a dark-red solid (6.42 g, quantitative yield).

2-nitro-4-(thiophen-2-yl)aniline

${ }^{1} \mathbf{H}$ NMR $\left(\mathrm{CDCl}_{3}, 400 \mathrm{MHz}\right): \delta 8.36(\mathrm{~d}, J=2.2 \mathrm{~Hz}, 1 \mathrm{H}), 7.62(\mathrm{dd}, J=8.7,2.2 \mathrm{~Hz}, 1 \mathrm{H}), 7.25-$ $7.23(\mathrm{~m}, 2 \mathrm{H}), 7.07(\mathrm{dd}, J=5.0,3.6 \mathrm{~Hz}, 1 \mathrm{H}), 6.84(\mathrm{~d}, J=8.7 \mathrm{~Hz}, 1 \mathrm{H}), 6.12(\mathrm{~s}, 2 \mathrm{H})$.

Step 1: Prepared according to General Procedure A with $\mathrm{MgSO}_{4}(35 \mathrm{~g}, 290 \mathrm{mmol}, 10$ equiv), 2-nitro-4-(thiophen-2-yl)aniline (6.42 g, $29.0 \mathrm{mmol}, 1.0$ equiv), $\mathrm{CH}_{2} \mathrm{Cl}_{2}(100 \mathrm{~mL})$ and isobutyraldehyde (18.0 mL, $197 \mathrm{mmol}, 6.8$ equiv). The resultant material was then dried under high vacuum for $12 \mathrm{~h}$ to give a dark-red solid containing some unreacted starting material (7.36 g, 92\% yield). This crude material was used in the subsequent step without further purification.

6-(thiophen-2-yl)- $N$-(2-methylprop-1-en-1-yl)-2-nitroaniline ${ }^{1} \mathbf{H}$ NMR $\left(\mathrm{CDCl}_{3}, 500 \mathrm{MHz}\right) \delta 9.67(\mathrm{~d}, J=9.5 \mathrm{~Hz}, 1 \mathrm{H}), 8.42(\mathrm{~d}, J=2.3 \mathrm{~Hz}, 1 \mathrm{H}), 7.69(\mathrm{dd}, J=$ 9.0, $2.3 \mathrm{~Hz}, 1 \mathrm{H}), 7.25-7.23(\mathrm{~m}, 2 \mathrm{H}), 7.10-7.03(\mathrm{~m}, 2 \mathrm{H}), 6.30$ (dt, $J=9.5,1.5 \mathrm{~Hz}, 1 \mathrm{H}), 1.89-1.72$ $(\mathrm{m}, 6 \mathrm{H})$.

Step 2: Prepared according to General Procedure A with $N$-(2-methylprop-1-en-1-yl)-2nitro-4-(thiophen-2-yl)aniline) (7.36 g, $29 \mathrm{mmol}, 1.0$ equiv), $t$-BuOH $(200 \mathrm{~mL}), t$-BuOK (13.1 g, $116 \mathrm{mmol}, 4.0$ equiv) and pivaloyl chloride (10.8 mL, $87.3 \mathrm{mmol}, 3.0$ equiv). The crude material was purified by flash chromatography to obtain a brown solid (3.2 g, 37\% yield). This material was further purified through recrystallization by dissolving with $100 \mathrm{~mL}$ of refluxing 10:90 EtOAc:hexane, then cooling in a $-5^{\circ} \mathrm{C}$ freezer to obtain $\mathbf{S 5}$ as colorless needles $(1.70 \mathrm{~g}, 19 \%$ yield).

${ }^{1}$ H NMR $\left(\mathrm{CDCl}_{3}, 400 \mathrm{MHz}\right): \delta 7.92(\mathrm{~s}, 1 \mathrm{H}), 7.79(\mathrm{~d}, J=8.5 \mathrm{~Hz}, 1 \mathrm{H}), 7.61-7.55(\mathrm{~m}, 1 \mathrm{H}), 7.38$ $(\mathrm{d}, J=8.5 \mathrm{~Hz}, 1 \mathrm{H}), 7.30(\mathrm{dd}, J=7.4,4.3 \mathrm{~Hz}, 2 \mathrm{H}), 7.12-7.06(\mathrm{~m}, 1 \mathrm{H}), 1.51(\mathrm{~s}, 9 \mathrm{H})$.

${ }^{13} \mathrm{C} \mathrm{NMR}\left(\mathrm{CDCl}_{3}, 126 \mathrm{MHz}\right): \delta 175.3,144.5,139.2,139.0,131.2,131.0,128.2,125.1,123.6$, 122.1, 121.5, 105.4, 38.9, 27.3.

IR (Diamond-ATR, neat, $\mathrm{cm}^{-1}$ ) $\tilde{v}_{\max }: 3118,2960,1791,1482,1449,1348,1285,1243,1228$, $1183,1056,1018,976,822$.

Melting Point $\left({ }^{\circ} \mathrm{C}\right): 135-136$.

HRMS (DART) m/z [M+H] $]^{+}$calcd. for $\mathrm{C}_{16} \mathrm{H}_{17} \mathrm{~N}_{2} \mathrm{O}_{2} \mathrm{~S}$ : 301.1005; Found: 301.1018 . 


\subsection{Synthesis and Characterization of 1,3-Butadienes}

The following 1,3-butadienes were prepared according to known protocols:<smiles>C=C/C=C/c1ccccc1</smiles>

$7^{\text {ref } 4}$<smiles>C=C/C=C/c1ccc(C(F)(F)F)cc1</smiles>

S8 ${ }^{\text {ref } 7}$<smiles>C=CC(=C)c1ccc(OC)cc1</smiles>

$\mathbf{S 1 3} 3^{\text {ref } 8}$<smiles>C=C/C=C(\C)c1ccccc1</smiles>

$\mathbf{S 6}{ }^{\text {ref } 5}$<smiles>C=C/C=C/c1ccc(OC)cc1</smiles>

S9ref 6<smiles>C=CC(=C)c1cn(C(=O)OCc2ccccc2)c2ccccc12</smiles>

S14 ${ }^{\text {ref } 8}$<smiles>C=C/C=C/c1cccc(Br)c1</smiles>

S7 ${ }^{\text {ref } 6}$<smiles>C=CC(=C)c1ccccc1</smiles>

S12 ${ }^{\text {ref } 8}$<smiles>C=CC(=C)c1ccc(Cl)cc1</smiles>

S15 ${ }^{\text {ref } 8}$<smiles>CC(C)(C)OC(=O)N1CCN(c2ccc(C=O)cc2)CC1</smiles>

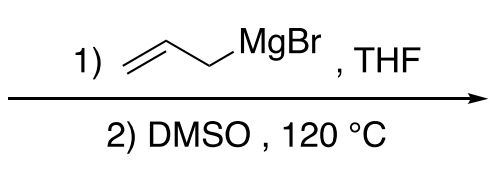<smiles>C=C/C=C/c1ccc(N2CCN(C(=O)OC(C)(C)C)CC2)cc1</smiles>

\section{tert-butyl (E)-4-(4-(buta-1,3-dien-1-yl)phenyl)piperazine-1-carboxylate (S10)}

A $50 \mathrm{~mL}$ round-bottom flask equipped with a magnetic stir bar was charged with tertbutyl 4-(4-formylphenyl)piperazine-1-carboxylate ( $1.0 \mathrm{~g}, 3.44 \mathrm{mmol}, 1.0$ equiv), sealed with a rubber septum and attached by rubber hose via a needle to a dual manifold Schlenk line. The flask was evacuated and backfilled with nitrogen (this process was repeated a total of three times). THF $(10 \mathrm{~mL})$ was added via syringe (by puncturing the rubber septum), the flask was cooled to $0{ }^{\circ} \mathrm{C}$ with the aid of an ice-water bath, then allyl magnesium bromide $(4.12 \mathrm{~mL}, 4.12$ mmol, 1.2 equiv, $1 \mathrm{M}$ in THF) was added dropwise via syringe (by puncturing the rubber septum). Once the addition was complete, the reaction flask was removed from the ice bath and allowed to stir for $1 \mathrm{~h}$ at $\mathrm{rt}$. The reaction mixture was quenched by the addition sat. aq. $\mathrm{NH}_{4} \mathrm{Cl}(10$ $\mathrm{mL}$ ) then the contents of the flask were transferred to a separatory funnel and extracted with $\mathrm{Et}_{2} \mathrm{O}$ $(3 \times 20 \mathrm{~mL})$. The combined organic layers were dried over $\mathrm{Na}_{2} \mathrm{SO}_{4}$, filtered, and concentrated in vacuo with the aid of a rotary evaporator. 
The resultant crude oil was transferred to a 5 dram vial equipped with a magnetic stir bar and dissolved in DMSO (5 mL from a Millipore-Sigma Sureseal ${ }^{\mathrm{TM}}$ bottle). The vial was capped and placed in an oil bath preheated to $120^{\circ} \mathrm{C}$ for $6 \mathrm{~h}$. At this time, the vial was allowed to cool to rt. The crude reaction mixture was transferred to a separatory funnel, diluted with $\mathrm{Et}_{2} \mathrm{O}(30 \mathrm{~mL})$, and washed with water $(5 \times 10 \mathrm{~mL})$. The ethereal layer was dried over $\mathrm{Na}_{2} \mathrm{SO}_{4}$, filtered, and concentrated in vacuo with the aid of a rotary evaporator. The crude material was purified by column chromatography (100 g silica, hexane to 20:80 EtOAc:hexane) to give $\mathbf{S 1 0}$ as a colorless solid (517 mg, $48 \%$ yield).

${ }^{1} \mathbf{H}$ NMR $\left(\mathrm{CDCl}_{3}, 500 \mathrm{MHz}\right): \delta 7.32(\mathrm{~d}, J=8.8 \mathrm{~Hz}, 2 \mathrm{H}), 6.86(\mathrm{~d}, J=8.8 \mathrm{~Hz}, 2 \mathrm{H}), 6.70-6.63(\mathrm{~m}$, $1 \mathrm{H}), 6.53-6.44(\mathrm{~m}, 2 \mathrm{H}), 5.27(\mathrm{~d}, J=16.9 \mathrm{~Hz}, 1 \mathrm{H}), 5.09(\mathrm{dd}, J=9.9,1.5 \mathrm{~Hz}, 1 \mathrm{H}), 3.57(\mathrm{t}, J=5.2$ $\mathrm{Hz}, 4 \mathrm{H}), 3.15$ (t, $J=5.2 \mathrm{~Hz}, 4 \mathrm{H}), 1.49$ (s, 9H).

${ }^{13} \mathrm{C}$ NMR $\left(\mathrm{CDCl}_{3}, 126 \mathrm{MHz}\right): \delta 154.9,150.8,137.6,132.6,130.2,129.2,127.6,127.4,116.4$, $116.3,80.1,49.1,28.6$.

IR (Diamond-ATR, neat, $\mathrm{cm}^{-1}$ ) $\tilde{v}_{\max }: 2975,2856,1694,1598,1514,1453,1412,1364,1222$, $1158,1122,1048,999,912,862,817$.

Melting Point $\left({ }^{\circ} \mathrm{C}\right): 101-104$.

HRMS (DART) m/z [M+H] $]^{+}$calcd. for $\mathrm{C}_{19} \mathrm{H}_{27} \mathrm{~N}_{2} \mathrm{O}_{2}$ : 315.2067; Found: 315.2072.
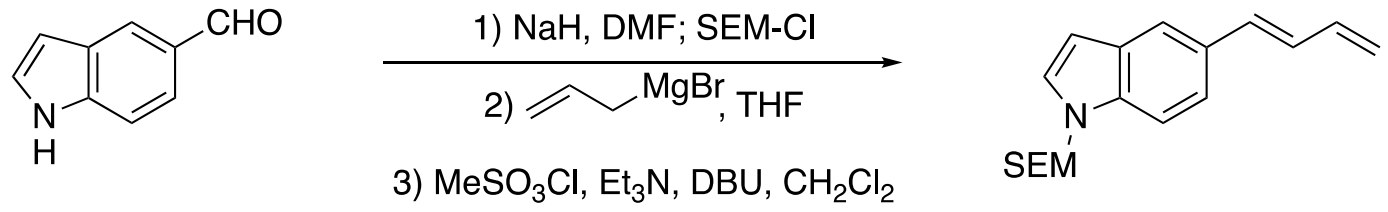

\section{(E)-5-(buta-1,3-dien-1-yl)-1-((2-(trimethylsilyl)ethoxy)methyl)-1H-indole (S11)}

An oven-dried $300 \mathrm{~mL}$ round-bottom flask equipped with a magnetic stir bar was charged with indole-5-carbaldehyde (1.65 g, $11.4 \mathrm{mmol}, 1.0$ equiv), sealed with a rubber septum. and attached by rubber hose via a needle to a dual manifold Schlenk line. The flask was evacuated and backfilled with nitrogen (this process was repeated a total of three times). DMF (40 mL from a Millipore-Sigma Sureseal ${ }^{\mathrm{TM}}$ bottle) was added via syringe (by puncturing the rubber septum), and the reaction mixture was cooled to $0{ }^{\circ} \mathrm{C}$ with the aid an ice-water bath. The rubber septum was removed and $\mathrm{NaH}$ (333 $\mathrm{mg}, 12.5 \mathrm{mmol}, 1.1$ equiv, 90\%) was added in three portions, resealing the flask with the rubber septum between additions. After the reaction mixture had stirred for $2 \mathrm{~h}, 2$-(trimethylsilyl)ethoxymethyl chloride (SEM-Cl) $(2.11 \mathrm{~mL}, 11.9 \mathrm{mmol}, 1.05$ equiv) was added via syringe (by puncturing the rubber septum), the reaction flask was removed from the ice-water bath, and the reaction was allowed to stir at $\mathrm{rt}$ for an additional $1 \mathrm{~h}$. The reaction mixture was quenched with sat. aq. $\mathrm{NH}_{4} \mathrm{Cl}(50 \mathrm{~mL})$, and the contents of the flask were transferred to a separatory funnel and extracted with $\mathrm{Et}_{2} \mathrm{O}(3 \times 100 \mathrm{~mL})$. The combined organic phase was washed with water $(3 \times 50 \mathrm{~mL})$, dried over $\mathrm{Na}_{2} \mathrm{SO}_{4}$, filtered, and concentrated in vacuo with the aid of a rotary evaporator. The crude material was purified by column chromatography 
(100 g silica, gradient elution, hexane to 10:90 EtOAc:hexane) to obtain the $N$-SEM protected indole (2.45 g, 78\% yield), which directly was used for the next step.

A $100 \mathrm{~mL}$ round-bottom flask equipped with a magnetic stir bar was charged with $\mathrm{N}$ SEM-indole-5-carbaldehyde ( $2.40 \mathrm{~g}, 8.70 \mathrm{mmol}, 1.0$ equiv), sealed with a rubber septum, and attached by rubber hose via a needle to a dual manifold Schlenk line. The flask was evacuated and backfilled with nitrogen (this process was repeated a total of three times). THF (30 mL) was added via syringe (by puncturing the rubber septum), then the reaction mixture was cooled to -78 ${ }^{\circ} \mathrm{C}$ with the aid of a dry ice/acetone bath. Allyl magnesium bromide $(6.5 \mathrm{~mL}, 13 \mathrm{mmol}, 1.5 \mathrm{equiv}$, $2 \mathrm{M}$ in THF) was added dropwise via syringe (by puncturing the rubber septum), then the reaction flask was removed from the dry ice/acetone bath. After $1 \mathrm{~h}$, the reaction mixture was quenched with sat. aq. $\mathrm{NH}_{4} \mathrm{Cl}(30 \mathrm{~mL})$ the contents of the flask were transferred to a separatory funnel and extracted with $\mathrm{Et}_{2} \mathrm{O}(3 \times 50 \mathrm{~mL})$. The combined organic layers were dried over $\mathrm{Na}_{2} \mathrm{SO}_{4}$, filtered through a short plug of silica $(3 \mathrm{~cm})$ in a fritted funnel, then concentrated in vacuo with the aid of a rotary evaporator. The resultant crude oil was used immediately and without further purification.

A $100 \mathrm{~mL}$ round-bottom flask equipped with a magnetic stir bar was charged with the allyl alcohol from the previous step ( $930 \mathrm{mg}, 2.93 \mathrm{mmol}, 1.0$ equiv), sealed with a rubber septum, and attached by rubber hose via a needle to a dual manifold Schlenk line. The flask was evacuated and backfilled with nitrogen (this process was repeated a total of three times). The flask was charged with $\mathrm{CH}_{2} \mathrm{Cl}_{2}(15 \mathrm{~mL})$, then wrapped in aluminum foil and cooled to $0{ }^{\circ} \mathrm{C}$ with the aid of an ice-water bath. $\mathrm{Et}_{3} \mathrm{~N}(0.74 \mathrm{~mL}, 5.27 \mathrm{mmol}, 1.8$ equiv) was charged via syringe (by puncturing the rubber septum), followed by methanesulfonyl chloride $(0.34 \mathrm{~mL}, 4.4 \mathrm{mmol}, 1.5$ equiv) via syringe (by puncturing the rubber septum), and the reaction mixture was allowed to stir at $0{ }^{\circ} \mathrm{C}$. After $4 \mathrm{~h}$ the reaction had not reached completion. 1,8-diazabicyclo[5.4.0]undec-7ene (DBU) (1.1 mL, $7.3 \mathrm{mmol}, 2.5$ equiv) was added by syringe (by puncturing the rubber septum) and the reaction was allowed to stir for another $4 \mathrm{~h}$ at $0{ }^{\circ} \mathrm{C}$. The reaction mixture was then concentrated in vacuo with the aid of a rotary evaporator and the resultant oil was purified by column chromatography (100 g silica, pentane) to obtain $\mathbf{S 1 1}$ as a colorless oil (400.0 $\mathrm{mg}$, $46 \%$ yield). S11 was used immediately in the allylation reaction below.

Note: S11 quickly turns yellow and solidifies on exposure to light. It should be stored in a scintillation vial or appropriate flask wrapped in aluminum foil at $-5^{\circ} \mathrm{C}$.

${ }^{1}$ H NMR $\left(\mathrm{CDCl}_{3}, 400 \mathrm{MHz}\right): \delta 7.63(\mathrm{~s}, 1 \mathrm{H}), 7.44(\mathrm{~d}, J=8.5 \mathrm{~Hz}, 1 \mathrm{H}), 7.37(\mathrm{dd}, J=8.6,1.6 \mathrm{~Hz}$, $1 \mathrm{H}), 7.15(\mathrm{~d}, J=3.2 \mathrm{~Hz}, 1 \mathrm{H}), 6.84-6.67(\mathrm{~m}, 2 \mathrm{H}), 6.59-6.49(\mathrm{~m}, 2 \mathrm{H}), 5.46(\mathrm{~s}, 2 \mathrm{H}), 5.29(\mathrm{~d}, J=$ $16.8 \mathrm{~Hz}, 1 \mathrm{H}), 5.11(\mathrm{dd}, J=10.1,1.6 \mathrm{~Hz}, 1 \mathrm{H}), 3.47(\mathrm{t}, J=8.3 \mathrm{~Hz}, 2 \mathrm{H}), 0.88(\mathrm{t}, J=8.3 \mathrm{~Hz}, 2 \mathrm{H})$, $-0.06(\mathrm{~s}, 9 \mathrm{H})$.

${ }^{13} \mathbf{C ~ N M R}\left(\mathrm{CDCl}_{3}, 126 \mathrm{MHz}\right): \delta 137.8,136.3,134.3,129.8,129.5,128.7,127.5,120.8,119.7$, $116.0,110.3,102.9,75.8,66.0,17.9,-1.3$. 


\section{Benzimidazole Allylation with Dienes and Characterization of Products}

\section{Table S3: Scope of Benzimidazole Allylation with Dienes}

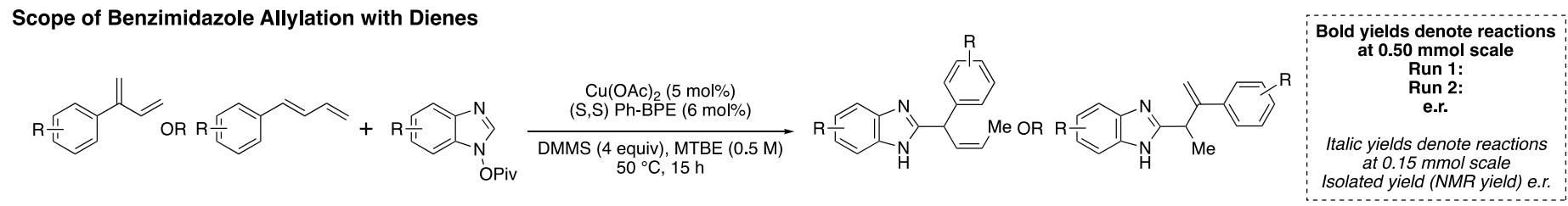

Benzimidazole Scope

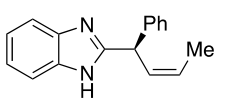<smiles>C/C=C\C(c1ccccc1)c1nc2ccc(C(F)(F)F)cc2[nH]1</smiles><smiles>C/C=C\C(c1ccccc1)c1nc2ccc(OC)cc2[nH]1</smiles>

8
Run 1: $89 \%$
Run 2: $93 \%$

Run 2: $93 \%$
95:5 e.r
9
Run 1: $62 \%$
Run 2: $62 \%$

95:5 e.r.

$$
\begin{gathered}
10 \\
\text { Run 1: } 71 \% \\
\text { Run 2: } 78 \% \\
97: 3 \text { e.r. }
\end{gathered}
$$

1-Substituted Butadiene Scope
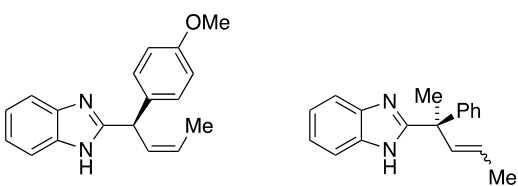

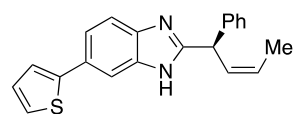

Me

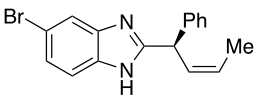

$$
\begin{gathered}
11 \\
\text { Run 1: } 84 \% \\
\text { Run 2: } 88 \% \\
96: 4 \text { e.r. }
\end{gathered}
$$

13

Run 2: $70 \%$

Run $3: 59 \%$
Run 1: $71 \%$

Run $2: 77 \%$
$94: 6$ e.r.
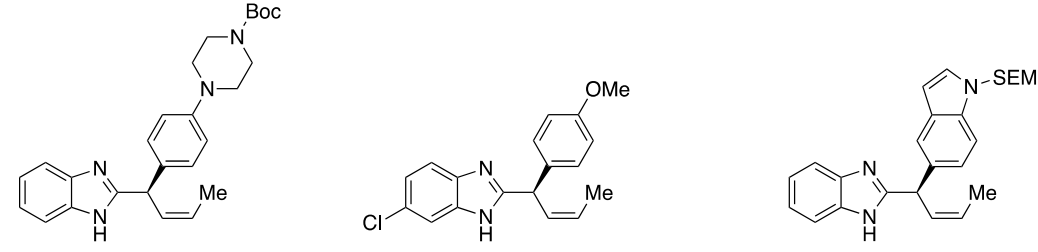

Run 1: $52 \%$

Run 1: $29 \%$

Run 2: $28 \%$

16
Run 1: $78 \%$

Run 1: $78 \%$
Run 2: $79 \%$

17

$96: 4$ e.r.

Run 1: $68 \%$
Run 2: $67 \%$
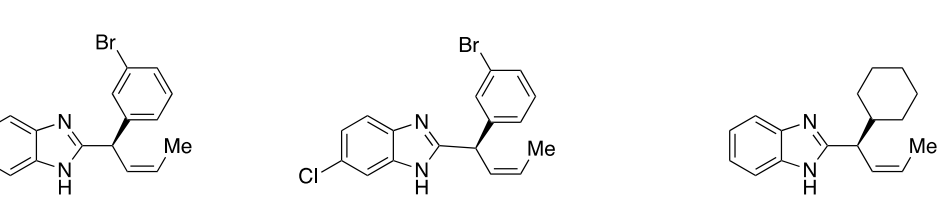

20
Run 1: $61 \%$
Run 2: $71 \%$

$0 \%$

18

Run 1: $59 \%$

un 2: $55 \%$

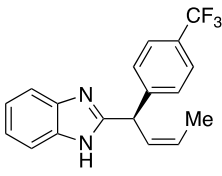

$70 \%$ (90\%) 83:17 e.r.

Run 1: $78 \%$

Run 2: $72 \%$

Run 2: $71 \%$

88:12 e.r.

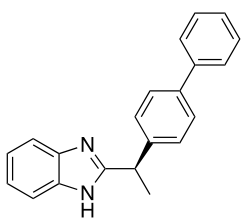

2-Substituted Butadiene Scope
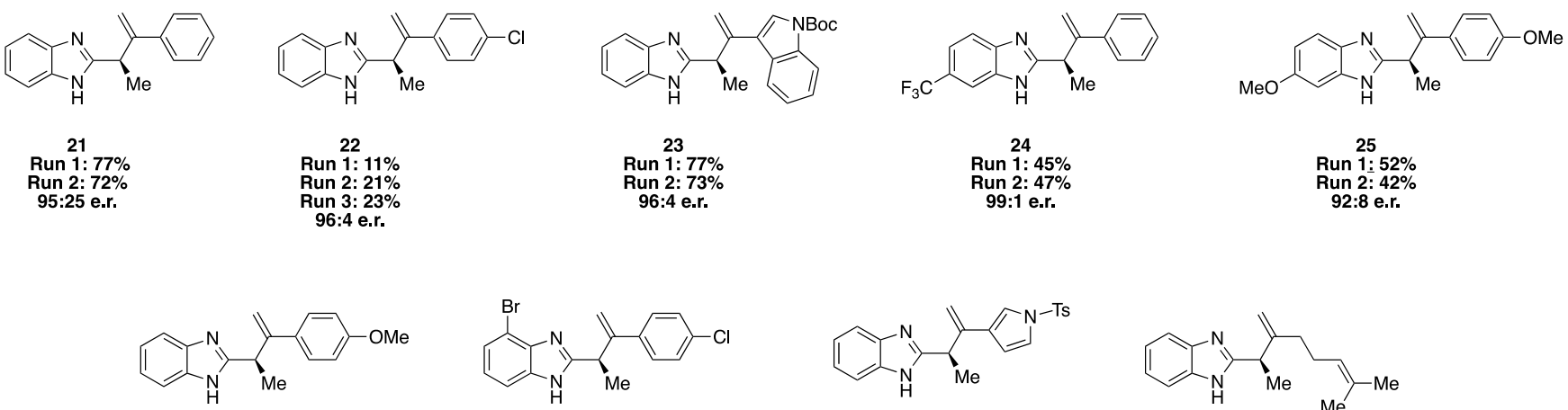

Run 2: $47 \%$

99:1 e.r.

Run $1: 52 \%$

Run 2: $42 \%$

92:8 e.r.

$67 \%$ (98\%) 94:6 e.r.

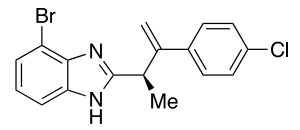
Run 1: $20 \%$
$89: 11$ e.r.

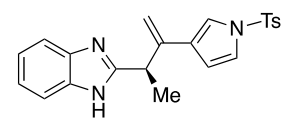

Run 1: $40 \%^{*}$ *formed precipitate *Several side products

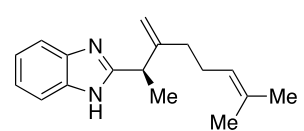

(30\%) 80:20 e.r. 
Supporting Information

\subsection{General Procedure $D$ for the Allylation of $N$-OPiv Benzimidazoles}

\section{Procedure:}

Inside a nitrogen filled glovebox, an oven-dried reaction tube (Fisherbrand, 13x100 mm, $1495935 \mathrm{C})$ equipped with a magnetic stir bar was charged with $\mathrm{Cu}(\mathrm{OAc})_{2}(4.5 \mathrm{mg}, 25.0 \mu \mathrm{mol}, 5$ mol\%), $(S, S)$-Ph-BPE (15 mg, $30.0 \mu \mathrm{mol}, 6 \mathrm{~mol} \%)$ and methyl tert-butyl ether $(1 \mathrm{~mL})$. This solution was capped with a screw cap containing a PTFE septum and allowed to stir for $10 \mathrm{~min}$. The cap was removed and dimethoxy(methyl)silane $(247 \mu \mathrm{L}, 2.00 \mathrm{mmol}, 4.0$ equiv) was added by pipette.

After stirring for $15 \mathrm{~min}$, the cap was removed and the diene ( $1.00 \mathrm{mmol}, 2.0$ equiv) was added to the reaction tube as a powder, or if liquid via pipette. The reaction tube was capped and the reaction mixture was allowed to stir for $10 \mathrm{~min}$, then the cap was removed and the appropriate $\mathrm{N}$-OPiv benzimidazole ( $0.500 \mathrm{mmol}, 1.0$ equiv) was added. The reaction tube was once again capped, removed from the glovebox and placed in an oil bath preheated to $50{ }^{\circ} \mathrm{C}$.

After the reaction mixture had stirred for $15 \mathrm{~h}$ at $50{ }^{\circ} \mathrm{C}$, the reaction tube was removed from the oil bath and allowed to cool to rt. Once at rt, the cap was removed from the reaction tube and the reaction mixture was quenched by the addition of sat. $\mathrm{NH}_{4} \mathrm{~F}$ in $\mathrm{MeOH}(5 \mathrm{~mL})$ and allowed to stir $5 \mathrm{~min}$. The reaction mixture was then transferred into a separatory funnel containing sat. aq. $\mathrm{NaHCO}_{3}(8 \mathrm{~mL})$, and the tube was rinsed with EtOAc $(8 \mathrm{~mL})$. The phases were separated, and the aq. phase was extracted with EtOAc $(2 \times 15 \mathrm{~mL})$. The combined organic layers were dried over $\mathrm{Na}_{2} \mathrm{SO}_{4}$, filtered through a fritted glass funnel, and concentrated in vacuo with the aid of a rotary evaporator.

The resultant crude material was dissolved in $\mathrm{CH}_{2} \mathrm{Cl}_{2}(1 \mathrm{~mL})$ and purified by column chromatography on silica gel that had been basified with eluent containing $1 \% \mathrm{Et}_{3} \mathrm{~N}$. The purified product was dried under high vacuum overnight, and the enantiomeric ratio was determined by chiral SFC.

\subsection{Characterization of Allylation Products}<smiles>C/C=C\C(c1ccccc1)c1nc2ccccc2[nH]1</smiles>

\section{(R,Z)-2-(1-phenylbut-2-en-1-yl)-1H-benzimidazole (8)}

Prepared according to General Procedure D using 1-phenyl- $E$-butadiene (7) $(140 \mu \mathrm{L}$, $1.00 \mathrm{mmol}, 2.0$ equiv) and $1 \mathrm{H}$-benzimidazol-1-yl pivalate (6) (109 mg, $0.500 \mathrm{mmol}, 1.0 \mathrm{equiv})$. The crude material was purified by column chromatography ( $40 \mathrm{~g}$ silica, gradient: $250 \mathrm{~mL}$ of 10:89:1, $250 \mathrm{~mL}$ of 20:79:1, $250 \mathrm{~mL}$ of 30:69:1, and $250 \mathrm{~mL}$ of 35:64:1 of EtOAc:hexane:Et ${ }_{3} \mathrm{~N}$ ) to afford 8 as a colorless solid ( $1^{\text {st }}$ run: $111 \mathrm{mg}, 89 \%$ yield, $96: 4$ e.r., $2^{\text {nd }}$ run: $115 \mathrm{mg}, 93 \%$ yield, 94:6 e.r.). 
${ }^{1} \mathbf{H}$ NMR $\left(\mathrm{CDCl}_{3}, 500 \mathrm{MHz}\right): \delta 9.27(\mathrm{~s}, 1 \mathrm{H}), 7.74(\mathrm{~d}, J=7.3 \mathrm{~Hz}, 1 \mathrm{H}), 7.35-7.30(\mathrm{~m}, 3 \mathrm{H}), 7.29-$ $7.25(\mathrm{~m}, 3 \mathrm{H}), 7.21(\mathrm{q}, J=4.0 \mathrm{~Hz}, 2 \mathrm{H}), 6.10-6.03(\mathrm{~m}, 1 \mathrm{H}), 5.80(\mathrm{dqd}, J=10.7,6.9,1.2 \mathrm{~Hz}, 1 \mathrm{H})$, $5.33-5.28(\mathrm{~m}, 1 \mathrm{H}), 1.72(\mathrm{dd}, J=6.9,1.8 \mathrm{~Hz}, 3 \mathrm{H})$.

${ }^{13} \mathrm{C} \mathrm{NMR}\left(\mathrm{CDCl}_{3}, 126 \mathrm{MHz}\right): \delta 155.8,143.5,141.1,133.7,129.2,129.1,128.1,127.5,127.4$, $122.8,122.2,119.7,110.6,43.8,13.3$.

IR (Diamond-ATR, neat, $\mathrm{cm}^{-1}$ ) $\widetilde{v}_{\max }:$ 2359, 2343, 2324, 1532, 1454, 1428, 1279, 932, 607, 600.

Melting Point $\left({ }^{\circ} \mathrm{C}\right): 186-188$.

HRMS (DART) m/z [M+H] ${ }^{+}$calcd. for $\mathrm{C}_{17} \mathrm{H}_{17} \mathrm{~N}_{2}$ : 249.1386; Found: 249.1395 .

Specific Rotation $[\alpha]^{23}:+2.7\left(\mathrm{c}=0.23, \mathrm{CHCl}_{3}\right)$.

Chiral SFC: Chiralcel AD-H (5:95 MeOH (0.1\% Et $\left.{ }_{2} \mathrm{NH}\right): \mathrm{scCO} 2$ to $20: 80 \mathrm{MeOH}(0.1 \%$ $\mathrm{Et}_{2} \mathrm{NH}$ ):scCO2 linear gradient over $20 \mathrm{~min}, 2.50 \mathrm{~mL} / \mathrm{min}$ ), $9.94 \mathrm{~min}$ (major), $9.07 \mathrm{~min}$ (minor). The absolute configuration was assigned by analogy to compound $\mathbf{1 3 .}$<smiles>C/C=C\C(c1ccccc1)c1nc2ccc(C(F)(F)F)cc2[nH]1</smiles>

\section{(R,Z)-2-(1-phenylbut-2-en-1-yl)-6-(trifluoromethyl)-1H-benzimidazole (9)}

Prepared according to General Procedure D using 1-phenyl- $E$-butadiene (7) $(140 \mu \mathrm{L}$, $1.00 \mathrm{mmol}, 2.0$ equiv) and 6-trifluoromethyl-1 $H$-benzimidazol-1-yl pivalate (S2) (143 mg, 0.500 mmol, 1.0 equiv). The crude material was purified by column chromatography (40 g silica, gradient: $350 \mathrm{~mL}$ of 10:89:1, $500 \mathrm{~mL}$ of 15:84:1, $500 \mathrm{~mL}$ of $20: 79: 1$, and $250 \mathrm{~mL}$ of $25: 74: 1$, EtOAc:hexane:Et $\left.{ }_{3} \mathrm{~N}\right)$ to afford 9 as a colorless solid ( $1^{\text {st }}$ run: $98 \mathrm{mg}, 62 \%$ yield, 97:3 e.r., $2^{\text {nd }}$ run: $98 \mathrm{mg}, 62 \%$ yield, $94: 6$ e.r.).

${ }^{1} \mathbf{H}$ NMR $\left(\mathrm{CDCl}_{3}, 500 \mathrm{MHz}\right)$ :

Major tautomer: $\delta 9.67(\mathrm{~s}, 1 \mathrm{H}), 7.98(\mathrm{~s}, 1 \mathrm{H}), 7.47(\mathrm{~d}, J=9.4 \mathrm{~Hz}, 1 \mathrm{H}), 7.39(\mathrm{~d}, J=8.7 \mathrm{~Hz}, 1 \mathrm{H})$, $7.35-7.29(\mathrm{~m}, 2 \mathrm{H}) 7.29-7.23(\mathrm{~m}, 3 \mathrm{H}), 6.05(\mathrm{t}, J=10.5 \mathrm{~Hz}, 1 \mathrm{H}), 5.82(\mathrm{dq}, J=13.8,6.9 \mathrm{~Hz}, 1 \mathrm{H})$, $5.31(\mathrm{dd}, J=9.2,3.2 \mathrm{~Hz}, 1 \mathrm{H}), 1.71(\mathrm{~d}, J=6.7,3 \mathrm{H})$.

Minor tautomer: $\delta 9.88(\mathrm{~s}, 1 \mathrm{H}), 7.75(\mathrm{~d}, J=8.0 \mathrm{~Hz}, 1 \mathrm{H}), 7.60(\mathrm{~s}, 1 \mathrm{H}), 7.47(\mathrm{~d}, J=9.4 \mathrm{~Hz}, 1 \mathrm{H})$, $7.35-7.29(\mathrm{~m}, 2 \mathrm{H}) 7.29-7.23(\mathrm{~m}, 3 \mathrm{H}), 6.05(\mathrm{t}, J=10.5 \mathrm{~Hz}, 1 \mathrm{H}), 5.82(\mathrm{dq}, J=13.8,6.9 \mathrm{~Hz}, 1 \mathrm{H})$, $5.31(\mathrm{dd}, J=9.2,3.2 \mathrm{~Hz}, 1 \mathrm{H}), 1.71(\mathrm{~d}, J=6.7 \mathrm{~Hz}, 3 \mathrm{H})$.

${ }^{13} \mathrm{C} \mathrm{NMR}\left(\mathrm{CDCl}_{3}, 126 \mathrm{MHz}\right): \delta 158.8,158.1,145.5,142.8,140.5,135.8,135.8,133.3,129.3$, 128.7, 128.6, 128.0, 128.0, 127.6, 126.0, 123.8, 121.7, 119.9, 119.7, 119.3, 117.2, 111.2, 108.6, $43.9,13.3$.

${ }^{19} \mathbf{F}$ NMR $\left(\mathrm{CDCl}_{3}, 471 \mathrm{MHz}\right): \delta-60.71$. 
IR (Diamond-ATR, neat, $\mathrm{cm}^{-1}$ ) $\tilde{v}_{\max }: 2722,1630,1600,1420,1326,1241,1155,1123,1006$, $890,696$.

Melting Point $\left({ }^{\circ} \mathrm{C}\right): 167-168$.

HRMS (DART) m/z [M+H] ${ }^{+}$calcd. for: $\mathrm{C}_{18} \mathrm{H}_{16} \mathrm{~F}_{3} \mathrm{~N}_{2}: 317.1260$; Found: 317.1268 .

Specific Rotation $[\alpha]^{23}{ }_{\mathrm{D}}:-1.4\left(\mathrm{c}=0.9, \mathrm{CHCl}_{3}\right)$.

Chiral SFC: Chiralcel AD-H (5:95 MeOH (0.1\% $\left.\mathrm{Et}_{2} \mathrm{NH}\right): \mathrm{scCO} 2$ to $20: 80 \mathrm{MeOH}(0.1 \%$ $\mathrm{Et}_{2} \mathrm{NH}$ ):scCO2 linear gradient over $20 \mathrm{~min}, 2.50 \mathrm{~mL} / \mathrm{min}$ ), $7.12 \mathrm{~min}$ (major), $5.89 \mathrm{~min}$ (minor). The absolute configuration was assigned by analogy to compound $\mathbf{1 3 .}$

Notes: Compound 9 exhibits tautomerization on the NMR timescale, with the compound in equilibrium with the trifluoromethyl in the 5 and 6 position.<smiles>C/C=C\C(c1ccccc1)c1nc2ccc(OC)cc2[nH]1</smiles>

(R,Z)-6-methoxy-2-(1-phenylbut-2-en-1-yl)-1H-benzimidazole (10)

Prepared according to General Procedure D using 1-phenyl- $E$-butadiene (7) $(140 \mu \mathrm{L}$, $1.00 \mathrm{mmol}, 2.0$ equiv) and 6-methoxy-1H-benzimidazol-1-yl pivalate (S3) (124 mg, $0.500 \mathrm{mmol}$, 1.0 equiv). The crude material was purified by column chromatography (40 g silica, gradient: 350 $\mathrm{mL}$ of 10:89:1, $350 \mathrm{~mL}$ of 15:84:1, $350 \mathrm{~mL}$ of $20: 79: 1,250 \mathrm{~mL}$ of $25: 74: 1,250 \mathrm{~mL}$ of $30: 69: 1$, and $250 \mathrm{~mL}$ of $35: 64: 1$, EtOAc:hexane:Et $\left.{ }_{3} \mathrm{~N}\right)$ to afford $\mathbf{1 0}$ as a colorless solid ( $1^{\text {st }}$ run: $100 \mathrm{mg}$, $71 \%$ yield, $97: 3$ e.r., $2^{\text {nd }}$ run: $109 \mathrm{mg}, 78 \%$ yield, 94:6 e.r.). A 55:45 ratio of tautomers was observed by ${ }^{1} \mathrm{H}$ NMR in $\mathrm{CDCl}_{3}$.

${ }^{1} \mathbf{H}$ NMR $\left(\mathrm{CDCl}_{3}, 500 \mathrm{MHz}\right)$ :

Major tautomer: $\delta 9.22(\mathrm{~s}, 1 \mathrm{H}), 7.59(\mathrm{~d}, J=8.2 \mathrm{~Hz}, 1 \mathrm{H}), 7.34-7.29(\mathrm{~m}, 2 \mathrm{H}), 7.28-7.24(\mathrm{~m}, 3 \mathrm{H})$, $7.23(\mathrm{~s}, 1 \mathrm{H}), 6.84(\mathrm{~d}, J=8.7 \mathrm{~Hz}, 1 \mathrm{H}), 6.05(\mathrm{t}, J=9.9 \mathrm{~Hz}, 1 \mathrm{H}), 5.78(\mathrm{dq}, J=13.8,6.8 \mathrm{~Hz}, 1 \mathrm{H})$, $5.26(\mathrm{~d}, J=8.9 \mathrm{~Hz}, 1 \mathrm{H}), 3.79(\mathrm{~d}, J=6.2 \mathrm{~Hz}, 3 \mathrm{H}), 1.71(\mathrm{~d}, J=6.4 \mathrm{~Hz}, 3 \mathrm{H})$.

Minor tautomer: $\delta 9.26(\mathrm{~s}, 1 \mathrm{H}), 7.34-7.29(\mathrm{~m}, 2 \mathrm{H}), 7.28-7.24(\mathrm{~m}, 3 \mathrm{H}), 7.18(\mathrm{~d}, J=8.5 \mathrm{~Hz}, 1 \mathrm{H})$, $6.84(\mathrm{~d}, J=8.7 \mathrm{~Hz}, 1 \mathrm{H}), 6.80(\mathrm{~s}, 1 \mathrm{H}), 6.05(\mathrm{t}, J=9.9 \mathrm{~Hz}, 1 \mathrm{H}), 5.78(\mathrm{dq}, J=13.8,6.8 \mathrm{~Hz}, 1 \mathrm{H})$, $5.26(\mathrm{~d}, J=8.9 \mathrm{~Hz}, 1 \mathrm{H}), 3.79(\mathrm{~d}, J=6.2 \mathrm{~Hz}, 3 \mathrm{H}), 1.71(\mathrm{~d}, J=6.4 \mathrm{~Hz}, 3 \mathrm{H})$.

${ }^{13} \mathrm{C} \mathrm{NMR}\left(\mathrm{CDCl}_{3}, 126 \mathrm{MHz}\right): \delta 156.4,155.5,141.1,129.2,129.1128 .7,128.1,127.4,127.4$, $111.9,56.0,43.8,34.3,22.5,14.2,13.3$.

IR (Diamond-ATR, neat, $\mathrm{cm}^{-1}$ ) $\widetilde{v}_{\max }: 2931,1631,1595,1492,1429,1269,1199,1160,1029$, $805,692$.

Melting Point ( $\left.{ }^{\circ} \mathrm{C}\right)$ : decomp. 126-133. 
HRMS (DART) m/z [M+H] $]^{+}$calcd. for $\mathrm{C}_{18} \mathrm{H}_{19} \mathrm{~N}_{2} \mathrm{O}$ : 279.1492; Found: 279.1493.

Specific Rotation $[\alpha]^{23}{ }_{\mathrm{D}}:-1.7\left(\mathrm{c}=0.30, \mathrm{CHCl}_{3}\right)$.

Chiral SFC: Chiralcel AD-H (5:95 MeOH (0.1\% $\left.\mathrm{Et}_{2} \mathrm{NH}\right): \mathrm{scCO} 2$ to $20: 80 \mathrm{MeOH}(0.1 \%$ $\mathrm{Et}_{2} \mathrm{NH}$ ): $\mathrm{scCO} 2$ linear gradient over $20 \mathrm{~min}, 2.50 \mathrm{~mL} / \mathrm{min}$ ), $13.13 \mathrm{~min}$ (major), $10.95 \mathrm{~min}$ (minor). The absolute configuration was assigned by analogy to compound $\mathbf{1 3}$.

Notes: Compound 10 exhibits tautomerization on the NMR timescale, with the compound in equilibrium with the methoxy group in the 5 and 6 position.<smiles>C/C=C\C(c1ccccc1)c1nc2ccc(-c3cccs3)cc2[nH]1</smiles>

(R,Z)-2-(1-phenylbut-2-en-1-yl)-6-(thiophen-2-yl)-1H-benzimidazole (11)

Prepared according to General Procedure D using 1-phenyl- $E$-butadiene (7) $(140 \mu \mathrm{L}$, $1.00 \mathrm{mmol}, 2.0$ equiv) and 6-(thiophen-2-yl)-1H-benzimidazol-1-yl pivalate (S5) $(150 \mathrm{mg}, 0.500$ mmol, 1.0 equiv). The crude material was purified by column chromatography (40 g silica, gradient: $250 \mathrm{~mL}$ of 10:89:1, $250 \mathrm{~mL}$ of 20:79:1, $500 \mathrm{~mL}$ of $25: 74: 1,500 \mathrm{~mL}$ of 30:69:1, and 500 $\mathrm{mL}$ of 35:64:1, EtOAc:hexane:Et ${ }_{3} \mathrm{~N}$ ) to afford 11 as a colorless solid ( $1^{\text {st }}$ run: $138 \mathrm{mg}, 84 \%$ yield 96:4 e.r., $2^{\text {nd }}$ run: $146 \mathrm{mg}, 88 \%$ yield, $96: 4$ e.r.). A 55:45 mixture of tautomers was observed by ${ }^{1} \mathrm{H} \mathrm{NMR}$ in $\mathrm{CDCl}_{3}$.

${ }^{1} \mathbf{H}$ NMR $\left(\mathrm{CDCl}_{3}, 500 \mathrm{MHz}\right)$ :

Major tautomer: $\delta 9.63(\mathrm{~s}, 1 \mathrm{H}), 7.68(\mathrm{~d}, J=8.4 \mathrm{~Hz}, 1 \mathrm{H}), 7.54(\mathrm{~s}, 1 \mathrm{H}), 7.49(\mathrm{~d}, J=8.8 \mathrm{~Hz}, 1 \mathrm{H})$, $7.36-7.18(\mathrm{~m}, 7 \mathrm{H}), 7.06(\mathrm{dd}, J=5.1,3.6 \mathrm{~Hz}, 1 \mathrm{H}), 6.07$ (tq, $J=9.3,1.8 \mathrm{~Hz}, 1 \mathrm{H}), 5.85-5.73(\mathrm{~m}$, $1 \mathrm{H}), 5.29(\mathrm{~d}, J=9.4 \mathrm{~Hz}, 1 \mathrm{H}), 1.70(\mathrm{dd}, J=6.9,1.8 \mathrm{~Hz}, 3 \mathrm{H})$.

Minor tautomer: $\delta 9.63(\mathrm{~s}, 1 \mathrm{H}) 7.97(\mathrm{~s}, 1 \mathrm{H}), 7.57-7.42(\mathrm{~m}, 1 \mathrm{H}), 7.36-7.18(\mathrm{~m}, 8 \mathrm{H}), 7.06(\mathrm{dd}, J=$ $5.1,3.6 \mathrm{~Hz}, 1 \mathrm{H}), 6.07(\mathrm{tq}, J=9.3,1.8 \mathrm{~Hz}, 1 \mathrm{H}), 5.85-5.73(\mathrm{~m}, 1 \mathrm{H}), 5.29(\mathrm{~d}, J=9.4 \mathrm{~Hz}, 1 \mathrm{H}), 1.70$ (dd, $J=6.9,1.8 \mathrm{~Hz}, 3 \mathrm{H})$.

${ }^{13} \mathrm{C} \mathrm{NMR}\left(\mathrm{CDCl}_{3}, 126 \mathrm{MHz}\right): \delta 156.9,156.7,145.4,145.3,144.0,143.1,140.9,134.3,133.5$, 129.6, 129.2, 128.9, 128.7, 128.1, 128.1, 127.6, 127.4, 124.4, 124.3, 122.9, 122.7, 121.7, 121.2, $119.8,116.9,111.0,108.2,43.9,13.3$.

IR (Diamond-ATR, neat, $\mathrm{cm}^{-1}$ ) $\tilde{v}_{\max }: 3025,1451,1414,1285,1225,1031,1005,846,807,738$, 691.

Melting Point $\left({ }^{\circ} \mathrm{C}\right): 98-102$.

HRMS (DART) m/z [M+H] $]^{+}$calcd. for $\mathrm{C}_{21} \mathrm{H}_{19} \mathrm{~N}_{2} \mathrm{~S}$ : 331.1263; Found: 331.1263.

Specific Rotation $[\alpha]^{23}$ : $+24.7\left(\mathrm{c}=1.27, \mathrm{CHCl}_{3}\right)$. 
Chiral SFC: Chiralcel AD-H (5:95 MeOH (0.1\% $\left.\mathrm{Et}_{2} \mathrm{NH}\right): \mathrm{scCO} 2$ to $20: 80 \mathrm{MeOH}(0.1 \%$ $\mathrm{Et}_{2} \mathrm{NH}$ ):scCO2 linear gradient over $20 \mathrm{~min}, 2.50 \mathrm{~mL} / \mathrm{min}$ ), $19.46 \mathrm{~min}$ (major), $17.84 \mathrm{~min}$ (minor). The absolute configuration was assigned by analogy to compound $\mathbf{1 3}$.

Notes: Compound 11 exhibits tautomerization on the NMR timescale, with the compound in equilibrium with the thiophene in the 5 and 6 position.<smiles>C/C=C\C(c1ccccc1)c1nc2ccc(Cl)cc2[nH]1</smiles>

\section{(R,Z)-6-chloro-2-(1-phenylbut-2-en-1-yl)-1H-benzimidazole (12)}

Prepared according to General Procedure D using 1-phenyl- $E$-butadiene (7) $(140 \mu \mathrm{L}$, $1.00 \mathrm{mmol}, 2.0$ equiv) and 6-chloro- $1 H$-benzimidazol-1-yl pivalate (S4) $(126 \mathrm{mg}, 0.500 \mathrm{mmol}$, 1.0 equiv). The crude material was purified by column chromatography (40 g silica, gradient: 350 $\mathrm{mL}$ of 10:89:1, $350 \mathrm{~mL}$ of 15:84:1, $350 \mathrm{~mL}$ of $20: 79: 1,250 \mathrm{~mL}$ of 25:74:1, $250 \mathrm{~mL}$ of 30:69:1 and $250 \mathrm{~mL}$ of $35: 64: 1$, EtOAc:hexane:Et ${ }_{3} \mathrm{~N}$ ) to afford 12 as a colorless solid ( $1^{\text {st }}$ run: $100 \mathrm{mg}$, $71 \%$ yield, $93: 7$ e.r., $2^{\text {nd }}$ run: $109 \mathrm{mg}, 77 \%$ yield, 96:4 e.r.). A 50:50 mixture of tautomers was observed by ${ }^{1} \mathrm{H}$ NMR in $\mathrm{CDCl}_{3}$.

${ }^{1} \mathbf{H} \mathbf{N M R}\left(\mathrm{CDCl}_{3}, 500 \mathrm{MHz}\right)$ :

Major tautomer: $\delta 9.73(\mathrm{~s}, 1 \mathrm{H}), 7.64(\mathrm{~s}, 1 \mathrm{H}), 7.57(\mathrm{~d}, J=8.7 \mathrm{~Hz}, 1 \mathrm{H}), 7.31(\mathrm{t}, J=7.4 \mathrm{~Hz}, 2 \mathrm{H})$, $7.28-7.21(\mathrm{~m}, 3 \mathrm{H}), 7.18-7.14(\mathrm{~m}, 1 \mathrm{H}) 6.03(\mathrm{t}, J=10.1 \mathrm{~Hz}, 1 \mathrm{H}), 5.79(\mathrm{dq}, J=13.7,6.8 \mathrm{~Hz}, 1 \mathrm{H})$, $5.26(\mathrm{~d}, J=9.1 \mathrm{~Hz}, 1 \mathrm{H}), 1.70(\mathrm{~d}, J=6.9 \mathrm{~Hz}, 3 \mathrm{H})$.

Minor tautomer: $\delta 9.63(\mathrm{~s}, 1 \mathrm{H}), 7.31(\mathrm{t}, J=7.4 \mathrm{~Hz}, 2 \mathrm{H}), 7.28-7.21(\mathrm{~m}, 4 \mathrm{H}), 7.20(\mathrm{~s}, 1 \mathrm{H}), 7.18-$ $7.14(\mathrm{~m}, 1 \mathrm{H}), 6.03(\mathrm{t}, J=10.1 \mathrm{~Hz}, 1 \mathrm{H}), 5.79(\mathrm{dq}, J=13.7,6.8 \mathrm{~Hz}, 1 \mathrm{H}), 5.26(\mathrm{~d}, J=9.1 \mathrm{~Hz}, 1 \mathrm{H})$, $1.70(\mathrm{~d}, J=6.9 \mathrm{~Hz}, 3 \mathrm{H})$.

${ }^{13} \mathrm{C}$ NMR $\left(\mathrm{CDCl}_{3}, 126 \mathrm{MHz}\right): \delta 157.4,156.8,144.3,142.0,140.7,134.4,132.3,129.2,128.8$, $128.7,128.4,128.0,127.8,127.7,127.5,123.3,122.9,120.3,119.4,111.5,110.9,43.8,13.3$.

IR (Diamond-ATR, neat, $\mathrm{cm}^{-1}$ ) $\widetilde{v}_{\max }: 2639,2359,1622,1586,1446,1422,1278,1223,1059$, 921, 803, 737, 598 .

Melting Point $\left({ }^{\circ} \mathrm{C}\right): 168-170$.

HRMS (DART) m/z [M+H] $]^{+}$calcd. for $\mathrm{C}_{17} \mathrm{H}_{16} \mathrm{ClN}_{2}$ : 283.0997; Found: 283.0995.

Specific Rotation $[\alpha]^{23}{ }_{\mathrm{D}}:+5.7\left(\mathrm{c}=0.37, \mathrm{CHCl}_{3}\right)$.

Chiral SFC: Chiralcel AD-H (5:95 MeOH (0.1\% $\left.\mathrm{Et}_{2} \mathrm{NH}\right): \mathrm{scCO} 2$ to $20: 80 \mathrm{MeOH}(0.1 \%$ $\mathrm{Et}_{2} \mathrm{NH}$ ):scCO2 linear gradient over $20 \mathrm{~min}, 2.50 \mathrm{~mL} / \mathrm{min}$ ), $12.00 \mathrm{~min}$ (major), $10.25 \mathrm{~min}$ (minor). The absolute configuration was assigned by analogy to compound $\mathbf{1 3}$.

Notes: Compound 12 exhibits tautomerization on the NMR timescale, with the compound in equilibrium with the chlorine in the 5 and 6 position. 


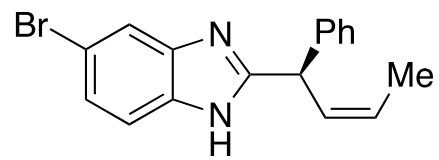

\section{( $R, Z)$-5-Bromo-2-(1-phenylbut-2-en-1-yl)-1H-benzimidazole (13)}

Prepared according to General Procedure D using 1-phenyl-E-butadiene (7) $(140 \mu \mathrm{L}$, $1.00 \mathrm{mmol}, 2.0$ equiv) and 5-bromo- $1 H$-benzimidazol-1-yl pivalate (S1) (149 mg, $0.500 \mathrm{mmol}$, 1.0 equiv). The crude material was purified by column chromatography (40 g silica, gradient: 350 $\mathrm{mL}$ of $10: 89: 1,350 \mathrm{~mL}$ of $15: 84: 1,350 \mathrm{~mL}$ of $20: 79: 1,250 \mathrm{~mL}$ of $25: 74: 1$, and $250 \mathrm{~mL}$ of 30:69:1, EtOAc:hexane:Et ${ }_{3} \mathrm{~N}$ ) to afford 13 as a colorless solid ( $1^{\text {st }}$ run: $82 \mathrm{mg}, 50 \%$ yield, 94:6 e.r., $2^{\text {nd }}$ run: $115 \mathrm{mg}, 70 \%$ yield, $96: 4$ e.r., $3^{\text {rd }}$ run: $96 \mathrm{mg}, 59 \%$ 96:4 e.r.). A 51:49 mixture of tautomers was observed by ${ }^{1} \mathrm{H}$ NMR in $\mathrm{CDCl}_{3}$.

${ }^{1} \mathbf{H} \mathbf{N M R}\left(\mathrm{CDCl}_{3}, 500 \mathrm{MHz}\right)$

Major tautomer: $\delta 9.88(\mathrm{~s}, 1 \mathrm{H}), 7.51(\mathrm{~d}, J=8.6 \mathrm{~Hz}, 1 \mathrm{H}), 7.42(\mathrm{~s}, 1 \mathrm{H}), 7.33-7.27(\mathrm{~m}, 3 \mathrm{H}), 7.25-$ $7.21(\mathrm{~m}, 2 \mathrm{H}), 7.16(\mathrm{~d}, J=8.6 \mathrm{~Hz}, 1 \mathrm{H}), 6.02(\mathrm{t}, J=10.3 \mathrm{~Hz}, 1 \mathrm{H}), 5.78(\mathrm{dq}, J=10.6,6.9 \mathrm{~Hz}, 1 \mathrm{H})$, $5.26(\mathrm{~d}, J=9.4 \mathrm{~Hz}, 1 \mathrm{H}), 1.69(\mathrm{~d}, J=6.9 \mathrm{~Hz}, 3 \mathrm{H})$.

Minor tautomer: $\delta 9.75(\mathrm{~s}, 1 \mathrm{H}), 7.79(\mathrm{~s}, 1 \mathrm{H}), 7.33-7.27(\mathrm{~m}, 4 \mathrm{H}), 7.25-7.21(\mathrm{~m}, 3 \mathrm{H}) 6.02(\mathrm{t}, J=$ $10.3 \mathrm{~Hz}, 1 \mathrm{H}), 5.78(\mathrm{dq}, J=10.6,6.9 \mathrm{~Hz}, 1 \mathrm{H}), 5.26(\mathrm{~d}, J=9.4 \mathrm{~Hz}, 1 \mathrm{H}), 1.69(\mathrm{~d}, J=6.9 \mathrm{~Hz}, 3 \mathrm{H})$.

${ }^{13} \mathrm{C}$ NMR $\left(\mathrm{CDCl}_{3}, 126 \mathrm{MHz}\right): \delta 157.2,156.8,144.7,142.3,140.7,134.9,132.7,129.2,128.7$, $128.7,128.0,127.8,127.7,127.5,125.9,125.5,122.4,120.7,115.9,115.2,113.9,112.0,43.8$, 13.3.

IR (Diamond-ATR, neat, $\mathrm{cm}^{-1}$ ) $\tilde{v}_{\max }: 2359,2340,2324,1621,1494,1443,1419,1277,909.801$, $730,698$.

Melting Point $\left({ }^{\circ} \mathrm{C}\right)$ : decomp. $172-175$.

Elemental Analysis calcd. for $\mathrm{C}_{17} \mathrm{H}_{15} \mathrm{BrN}_{2}$ : C, $62.40 \%$ H, 4.62\%; Found: C, $62.14 \%$ H. 4.59\%.

Specific Rotation $[\alpha]^{23}{ }_{\mathrm{D}}:+6.2\left(\mathrm{c}=0.11, \mathrm{CHCl}_{3}\right)$.

Chiral SFC: Chiralcel AD-H (5:95 MeOH (0.1\% $\left.\mathrm{Et}_{2} \mathrm{NH}\right)$ :scCO2 to 20:80 $\mathrm{MeOH}(0.1 \%$ $\mathrm{Et}_{2} \mathrm{NH}$ ):scCO2 linear gradient over $20 \mathrm{~min}, 2.50 \mathrm{~mL} / \mathrm{min}$ ), $13.24 \mathrm{~min}$ (major), $11.44 \mathrm{~min}$ (minor). The absolute configuration was determined by single crystal x-ray diffraction.

Notes: Compound 13 exhibits tautomerization on the NMR timescale, with the compound in equilibrium with the bromine in the 5 position and the 6 position. This was corroborated by the single crystal $\mathrm{x}$-ray diffraction data (see section $\mathbf{5 . 1}$ and 5.2). 


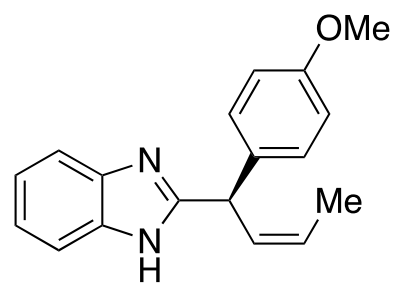

(R,Z)-2-(1-(4-methoxyphenyl)but-2-en-1-yl)-1H-benzimidazole (14)

Prepared according to General Procedure D using 1-( $p$-methoxyphenyl)- $E$-butadiene (S9) (160 mg, $1.00 \mathrm{mmol}, 2.0$ equiv) and 1 $H$-benzimidazol-1-yl pivalate (6) (109 mg, 0.500 mmol, 1.0 equiv). The crude material was purified by column chromatography (40 g silica, gradient: $500 \mathrm{~mL}$ of $10: 89: 1,350 \mathrm{~mL}$ of $15: 84: 1,350 \mathrm{~mL}$ of $20: 79: 1,250 \mathrm{~mL}$ of $25: 74: 1,250 \mathrm{~mL}$ of $30: 69: 1,250 \mathrm{~mL}$ of $35: 64: 1,500 \mathrm{~mL}$ of $40: 59: 1,250 \mathrm{~mL}$ of $45: 54: 1$, and $250 \mathrm{~mL}$ of $50: 49: 1$, EtOAc:hexane:Et ${ }_{3} \mathrm{~N}$ ) to obtain 14 as a solid ( $1^{\text {st }}$ run: $82 \%$ yield, $2^{\text {nd }}$ run: $92 \%$ yield). The solid was then triturated with $1.5 \mathrm{~mL}$ of $\mathrm{MeCN}$, filtered, and dried under high vacuum to obtain analytically pure 14 as a colorless solid ( $1^{\text {st }}$ run: $72 \mathrm{mg}, 52 \%$ yield, $98: 2$ e.r., $2^{\text {nd }}$ run: $82 \mathrm{mg}, 59 \%$, 97:3 e.r.).

${ }^{1} \mathbf{H}$ NMR $\left(\mathrm{CDCl}_{3}, 500 \mathrm{MHz}\right): \delta 8.79(\mathrm{~s}, 1 \mathrm{H}), 7.76(\mathrm{~d}, J=7.4 \mathrm{~Hz}, 1 \mathrm{H}), 7.33(\mathrm{dd}, J=7.0,1.9 \mathrm{~Hz}$, $1 \mathrm{H}), 7.21(\mathrm{dq}, J=7.5,5.7 \mathrm{~Hz}, 4 \mathrm{H}), 6.90-6.86(\mathrm{~m}, 2 \mathrm{H}), 6.04(\mathrm{tq}, J=9.2,1.8 \mathrm{~Hz}, 1 \mathrm{H}), 5.86-5.78$ $(\mathrm{m}, 1 \mathrm{H}), 5.27(\mathrm{~d}, J=9.3 \mathrm{~Hz}, 1 \mathrm{H}), 3.79(\mathrm{~s}, 3 \mathrm{H}), 1.75(\mathrm{dd}, J=6.9,1.8 \mathrm{~Hz}, 3 \mathrm{H})$.

${ }^{13} \mathrm{C} \mathrm{NMR}\left(\mathrm{CDCl}_{3}, 126 \mathrm{MHz}\right): \delta 159.0,156.2,143.6,133.6,133.0,129.3,129.2,127.3,122.8$, $122.2,119.8,114.6,110.5,55.5,43.0,13.4$.

IR (Diamond-ATR, neat, $\mathrm{cm}^{-1}$ ) $\tilde{v}_{\max }: 2840,1614,1513,1453,1429,1307,1271,1178,1031$, 1008, 934, 813, 740, 696.

Melting Point $\left({ }^{\circ} \mathrm{C}\right): 209-216$.

HRMS (DART) m/z [M+H] $]^{+}$calcd. for $\mathrm{C}_{18} \mathrm{H}_{19} \mathrm{~N}_{2} \mathrm{O}$ : 279.1492; Found: 279.1499.

Specific Rotation $[\alpha]^{23}{ }_{\mathrm{D}}:-7.4\left(\mathrm{c}=0.52, \mathrm{CHCl}_{3}\right)$.

Chiral SFC: Chiralcel AD-H (5:95 MeOH (0.1\% $\left.\mathrm{Et}_{2} \mathrm{NH}\right)$ :scCO2 to 20:80 $\mathrm{MeOH}(0.1 \%$ $\mathrm{Et}_{2} \mathrm{NH}$ ): $\mathrm{scCO} 2$ linear gradient over $20 \mathrm{~min}, 2.50 \mathrm{~mL} / \mathrm{min}$ ), $11.53 \mathrm{~min}$ (major), $10.89 \mathrm{~min}$ (minor). The absolute configuration was assigned by analogy to compound $\mathbf{1 3}$.<smiles>C/C=C\[C@](C)(c1ccccc1)c1nc2ccccc2[nH]1</smiles>

(R)-2-(2-phenylpent-3-en-2-yl)-1 $H$-benzimidazole (15)

Prepared according to General Procedure D using 2-phenylpenta-2,4-diene (S6) (162 $\mu \mathrm{L}, 1.00 \mathrm{mmol}, 2.0$ equiv) and $1 H$-benzimidazol-1-yl pivalate (6) (109 $\mathrm{mg}, 0.500 \mathrm{mmol}, 1.0$ equiv). The crude material was purified by column chromatography ( $40 \mathrm{~g}$ silica, gradient: 500 $\mathrm{mL}$ of $10: 89: 1,500 \mathrm{~mL}$ of $15: 84: 1,500 \mathrm{~mL}$ of $20: 79: 1$, and $500 \mathrm{~mL}$ of $25: 74: 1$, EtOAc:hexane:Et ${ }_{3} \mathrm{~N}$ ) to afford 15 as a colorless solid ( $1^{\text {st }}$ run: $38 \mathrm{mg}, 29 \%$ yield, 82:18 E:Z, 96:4 
e.r. ( $E$ isomer), $99: 1$ e.r. ( $Z$ isomer). $2^{\text {nd }}$ run: $37 \mathrm{mg}, 28 \%$ yield, $81: 19 E: Z, 96: 4$ e.r. ( $E$ isomer), 99:1 e.r. $(Z$ isomer $)$ ).

1H NMR: Z Z-Isomer: $\left(\mathrm{CDCl}_{3}, 500 \mathrm{MHz}\right) \delta 8.70(\mathrm{~s}, 1 \mathrm{H}), 7.83(\mathrm{~d}, J=8.4 \mathrm{~Hz}, 1 \mathrm{H}), 7.37-7.32(\mathrm{~m}$, $4 \mathrm{H}), 7.31-7.27(\mathrm{~m}, 2 \mathrm{H}), 7.25(\mathrm{qd}, J=7.5,1.5 \mathrm{~Hz}, 2 \mathrm{H}), 6.27(\mathrm{dq}, J=11.5,1.8 \mathrm{~Hz}, 1 \mathrm{H})$, $5.79(\mathrm{dq}, J=11.5,7.3 \mathrm{~Hz}, 1 \mathrm{H}), 2.08(\mathrm{~s}, 3 \mathrm{H}), 1.24(\mathrm{dd}, J=7.3,1.8 \mathrm{~Hz}, 3 \mathrm{H})$.

E-Isomer: $\left(\mathrm{CDCl}_{3}, 500 \mathrm{MHz}\right) \delta 8.70(\mathrm{~s}, 1 \mathrm{H}), 7.83(\mathrm{~d}, J=8.4 \mathrm{~Hz}, 1 \mathrm{H}), 7.37-7.32(\mathrm{~m}, 4 \mathrm{H})$, $7.31-7.27$ (m, 2H), 7.25 (qd, $J=7.5,1.5 \mathrm{~Hz}, 2 \mathrm{H}), 6.13(\mathrm{dq}, J=15.5,1.7 \mathrm{~Hz}, 1 \mathrm{H}), 5.43$ (dq, $J=15.5,6.5 \mathrm{~Hz}, 1 \mathrm{H}), 2.01(\mathrm{~s}, 3 \mathrm{H}), 1.79(\mathrm{dd}, J=6.5,1.7 \mathrm{~Hz}, 3 \mathrm{H})$.

${ }^{13} \mathbf{C ~ N M R}\left(\mathrm{CDCl}_{3}, 126 \mathrm{MHz}\right): \delta 159.0,145.5,143.1,136.2,136.1,133.5,128.7,128.7,128.6$, $128.0,127.3,127.1,127.0,126.9,126.3,122.7,122.0,122.0,119.8,119.8,110.4,110.4,47.8$, $46.6,28.5,27.0,18.1,14.0$.

IR (Diamond-ATR, neat, $\mathrm{cm}^{-1}$ ) $\tilde{v}_{\max }: 3059,2980,2359,1620,1591,1490,1406,1369,1274$, $1226,977,744,702$.

Melting Point $\left({ }^{\circ} \mathrm{C}\right): 215-219$.

HRMS (DART) m/z [M+H] ${ }^{+}$calcd. for $\mathrm{C}_{18} \mathrm{H}_{19} \mathrm{~N}_{2}$ : 263.1543; Found: 263.1546.

Specific Rotation $[\alpha]^{23}$ : $-34.1\left(\mathrm{c}=0.20, \mathrm{CHCl}_{3}\right)$.

Chiral HPLC: Chiralcel OJ-H (85:15 hexane:IPA, isocratic, $0.8 \mathrm{~mL} / \mathrm{min}), Z: 5.67 \mathrm{~min}$ (minor), $6.42 \mathrm{~min}$ (major). $E$ : $7.15 \mathrm{~min}$ (major), $10.14 \mathrm{~min}$ (minor). The absolute configuration was assigned by analogy to compound $\mathbf{1 3}$.

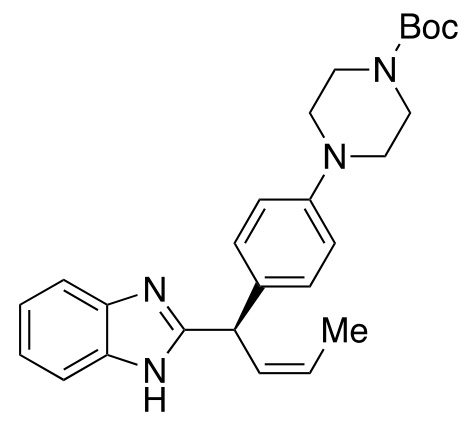

\section{tert-butyl $(R, Z)-4-(4-(1-(1 H$-benzimidazol-2-yl)but-2-en-1-yl)phenyl)piperazine-1- carboxylate (16)}

Prepared according to General Procedure D using tert-butyl (E)-4-(4-(buta-1,3-dien-1yl)phenyl)piperazine-1-carboxylate (S10) (314 mg, $1.00 \mathrm{mmol}, 2.0$ equiv) and $1 H$-benzimidazol1-yl pivalate (6) (109 $\mathrm{mg}, 0.500 \mathrm{mmol}, 1.0$ equiv). The crude material was purified by column chromatography (40 g silica, gradient: $250 \mathrm{~mL}$ of 12:87:1, $250 \mathrm{~mL}$ of $20: 79: 1,250 \mathrm{~mL}$ of 30:69:1, $250 \mathrm{~mL}$ of 40:59:1, and $250 \mathrm{~mL}$ of 45:54:1, EtOAc:hexane: $\mathrm{Et}_{3} \mathrm{~N}$ ) to afford 16 as a colorless solid ( $1^{\text {st }}$ run: $169 \mathrm{mg}, 78 \%$ yield, $96: 4$ e.r., $2^{\text {nd }}$ run: $171 \mathrm{mg}, 79 \%$ yield 96:4 e.r.). 
${ }^{1} \mathbf{H}$ NMR $\left(\mathrm{CDCl}_{3}, 500 \mathrm{MHz}\right): \delta 9.67(\mathrm{~s}, 1 \mathrm{H}), 7.70(\mathrm{~s}, 1 \mathrm{H}), 7.29(\mathrm{~s}, 1 \mathrm{H}), 7.17(\mathrm{dd}, J=9.7,6.7 \mathrm{~Hz}$, $4 \mathrm{H}), 6.83(\mathrm{~d}, J=8.7 \mathrm{~Hz}, 2 \mathrm{H}), 6.05(\mathrm{tq}, J=9.4,1.8 \mathrm{~Hz}, 1 \mathrm{H}), 5.79-5.71(\mathrm{~m}, 1 \mathrm{H}), 5.23(\mathrm{~d}, J=9.4$ $\mathrm{Hz}, 1 \mathrm{H}), 3.53$ (t, $J=5.0 \mathrm{~Hz}, 4 \mathrm{H}), 3.06(\mathrm{t}, J=5.2 \mathrm{~Hz}, 4 \mathrm{H}), 1.70(\mathrm{dd}, J=6.9,1.8 \mathrm{~Hz}, 3 \mathrm{H}), 1.48$ (s, $9 \mathrm{H})$.

${ }^{13} \mathrm{C} \mathrm{NMR}\left(\mathrm{CDCl}_{3}, 126 \mathrm{MHz}\right): \delta 156.4,154.9,150.4,143.5,133.9,132.6,129.3,128.8,126.9$, 122.6, 122.0, 119.6, 117.1, 116.1, 110.7, 80.1, 49.4, 42.9, 28.6, 13.3.

IR (Diamond-ATR, neat, $\mathrm{cm}^{-1}$ ) $\tilde{v}_{\max }: 2978,2839,1695,1613,1515,1454,1268,1226,999,926$, $736,668$.

Melting Point $\left({ }^{\circ} \mathrm{C}\right)$ : decomp. 203-204.

HRMS (DART) m/z [M+H] $]^{+}$calcd. for $\mathrm{C}_{26} \mathrm{H}_{33} \mathrm{~N}_{4} \mathrm{O}_{2}$ : 433.2598; Found: 433.2605.

Specific Rotation $[\alpha]^{23}$ : $-37.1\left(\mathrm{c}=1.23, \mathrm{CHCl}_{3}\right)$.

Chiral SFC: Chiralcel OD-H (5:95 MeOH (0.1\% $\left.\mathrm{Et}_{2} \mathrm{NH}\right): \mathrm{scCO} 2$ to 20:80 $\mathrm{MeOH}(0.1 \%$ $\mathrm{Et}_{2} \mathrm{NH}$ ): $\mathrm{scCO} 2$ linear gradient over $20 \mathrm{~min}, 2.50 \mathrm{~mL} / \mathrm{min}$ ) $16.64 \mathrm{~min}$ (major), $15.84 \mathrm{~min}$ (minor). The absolute configuration was assigned by analogy to compound $\mathbf{1 3}$.<smiles>C/C=C\C(c1ccc(OC)cc1)c1nc2ccc(Cl)cc2[nH]1</smiles>

\section{(R,Z)-6-chloro-2-(1-(4-methoxyphenyl)but-2-en-1-yl)-1H-benzimidazole (17)}

Prepared according to General Procedure D using 1-( $p$-methoxyphenyl)- $E$-butadiene (S9) (160 mg, $1.00 \mathrm{mmol}, 2.0$ equiv) and 6-chloro-1H-benzimidazol-1-yl pivalate (S4) (126 mg, $0.500 \mathrm{mmol}, 1.0$ equiv). The crude material was purified by column chromatography (40 g silica, gradient: $250 \mathrm{~mL}$ of 10:89:1, $250 \mathrm{~mL}$ of 20:79:1, $250 \mathrm{~mL}$ of 30:69:1 and $250 \mathrm{~mL}$ of 40:59:1, EtOAc:hexane:Et $\left.{ }_{3} \mathrm{~N}\right)$ to afford 17 as a colorless solid ( $1^{\text {st }}$ run: $106 \mathrm{mg}, 68 \%$ yield, 89:11 e.r. $2^{\text {nd }}$ run: $104 \mathrm{mg}, 67 \%$ yield, $91: 9$ e.r.). A 50:50 mixture of tautomers was observed by ${ }^{1} \mathrm{H}$ NMR in $\mathrm{CDCl}_{3}$.

${ }^{1} \mathbf{H}$ NMR: $\left(\mathrm{CDCl}_{3}, 500 \mathrm{MHz}\right)$ :

Major tautomer: $\delta 9.87(\mathrm{~s}, 1 \mathrm{H}), 7.55(\mathrm{~s}, 1 \mathrm{H}), 7.37-7.10(\mathrm{bs}, 1 \mathrm{H}), 7.18-7.10(\mathrm{~m}, 3 \mathrm{H}), 6.82(\mathrm{~d}, J=$ $8.7 \mathrm{~Hz}, 2 \mathrm{H}), 6.00(\mathrm{tq}, J=9.4,1.8 \mathrm{~Hz}, 1 \mathrm{H}), 5.76(\mathrm{dqd}, J=10.6,6.9,1.1 \mathrm{~Hz}, 1 \mathrm{H}), 5.21(\mathrm{~d}, J=9.3$ $\mathrm{Hz}, 1 \mathrm{H}), 3.75$ (s, 3H), 1.68 (dd, $J=6.9,1.8 \mathrm{~Hz}, 3 \mathrm{H})$.

Minor tautomer: $\delta 9.75(\mathrm{~s}, 1 \mathrm{H}), 7.62(\mathrm{~s}, 1 \mathrm{H}), 7.37-7.10(\mathrm{bs}, 1 \mathrm{H}), 7.18-7.10(\mathrm{~m}, 3 \mathrm{H}), 6.82(\mathrm{~d}, J=$ $8.7 \mathrm{~Hz}, 2 \mathrm{H}), 6.00$ (tq, $J=9.4,1.8 \mathrm{~Hz}, 1 \mathrm{H}), 5.76(\mathrm{dqd}, J=10.6,6.9,1.1 \mathrm{~Hz}, 1 \mathrm{H}), 5.21(\mathrm{~d}, J=9.3$ $\mathrm{Hz}, 1 \mathrm{H}), 3.75$ (s, 3H), 1.68 (dd, $J=6.9,1.8 \mathrm{~Hz}, 3 \mathrm{H})$. 
${ }^{13} \mathrm{C} \mathrm{NMR}\left(\mathrm{CDCl}_{3}, 126 \mathrm{MHz}\right): \delta 159.0,157.5,132.7,131.0,130.5,130.0,129.1,129.0,128.1$, $127.5,123.0,114.6,114.1,55.4,43.0,13.3$.

IR (Diamond-ATR, neat, $\mathrm{cm}^{-1}$ ) $\tilde{v}_{\max }: 2912,2834,2703,2358,1608,1582,1511,1441,1423$, $1277,1181,1029,809,685$.

Melting Point $\left({ }^{\circ} \mathrm{C}\right): 169-171$.

Elemental Analysis calcd. for $\mathrm{C}_{18} \mathrm{H}_{17} \mathrm{ClN}_{2} \mathrm{O}$ : C, 69.12\% H, 5.48\%; Found: C, 69.00\% H, 5.67\%.

Specific Rotation $[\alpha]^{23}$ : $-13.5\left(\mathrm{c}=0.63, \mathrm{CHCl}_{3}\right)$.

Chiral SFC: Chiralcel AD-H (5:95 MeOH (0.1\% $\left.\mathrm{Et}_{2} \mathrm{NH}\right): \mathrm{scCO} 2$ to $20: 80 \mathrm{MeOH}(0.1 \%$ $\mathrm{Et}_{2} \mathrm{NH}$ ):scCO2 linear gradient over $20 \mathrm{~min}, 2.50 \mathrm{~mL} / \mathrm{min}$ ), $14.27 \mathrm{~min}$ (major), $12.68 \mathrm{~min}$ (minor). The absolute configuration was assigned by analogy to compound $\mathbf{1 3}$.

Notes: Compound 17 exhibits tautomerization on the NMR timescale, with the compound in equilibrium with the chlorine in the 5 and 6 position.

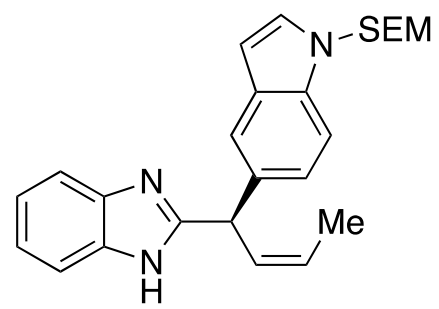

(R,Z)-2-(1-(1-((2-(trimethylsilyl)ethoxy)methyl)-1H-indol-5-yl)but-2-en-1-yl)-1Hbenzimidazole (18)

Prepared according to a modified General Procedure D using (E)-5-(buta-1,3-dien-1-yl)1-((2-(trimethylsilyl)ethoxy)methyl)- $1 H$-indole (S11) $(250 \mathrm{mg}, .840 \mathrm{mmol}, 1.66$ equiv) and $1 H$ benzimidazol-1-yl pivalate (6) (109 $\mathrm{mg}, 0.500 \mathrm{mmol}, 1.0$ equiv). To protect the photosensitive diene, the reaction tube was wrapped in aluminum foil. The crude material was purified by column chromatography (40 g silica, gradient: $250 \mathrm{~mL}$ of 10:89:1, $500 \mathrm{~mL}$ of 15:84:1, and 1000 $\mathrm{mL}$ of 20:79:1, EtOAc:hexane:Et ${ }_{3} \mathrm{~N}$ ) to afford 18 as a colorless solid. ( ${ }^{\text {st }}$ run: $124 \mathrm{mg}, 59 \%$ yield, $96: 4$ e.r., $2^{\text {nd }}$ run: $114 \mathrm{mg}, 55 \%$ yield, 96:4 e.r.).

${ }^{1} \mathbf{H}$ NMR $\left(\mathrm{CDCl}_{3}, 500 \mathrm{MHz}\right): \delta 9.26(\mathrm{~s}, 1 \mathrm{H}), 7.53(\mathrm{~s}, 1 \mathrm{H}), 7.84-7.28(\mathrm{bs}, 2 \mathrm{H}), 7.43(\mathrm{~d}, J=8.5$ $\mathrm{Hz}, 1 \mathrm{H}), 7.18$ (dd, $J=7.1,3.3 \mathrm{~Hz}, 3 \mathrm{H}), 7.13(\mathrm{dd}, J=8.5,1.7 \mathrm{~Hz}, 1 \mathrm{H}), 6.47(\mathrm{~d}, J=3.2 \mathrm{~Hz}, 1 \mathrm{H})$, $6.17(\mathrm{tq}, J=9.41 .8 \mathrm{~Hz}, 1 \mathrm{H}), 5.78(\mathrm{dqd}, J=10.6,6.8,1.1 \mathrm{~Hz}, 1 \mathrm{H}), 5.44(\mathrm{~s}, 2 \mathrm{H}), 5.37(\mathrm{~d}, J=9.3$ $\mathrm{Hz}, 1 \mathrm{H}), 3.47$ (t, $J=8.1 \mathrm{~Hz}, 2 \mathrm{H}), 1.72(\mathrm{dd}, J=6.9,1.8 \mathrm{~Hz}, 3 \mathrm{H}), 0.89$ (dd, $J=8.8,7.6 \mathrm{~Hz}, 2 \mathrm{H})$, -0.05 (s, 9H).

${ }^{13} \mathrm{C}$ NMR $\left(\mathrm{CDCl}_{3}, 126 \mathrm{MHz}\right): \delta 157.0,135.7,132.8,132.0,130.8,129.8,129.6,128.8,126.7$, $126.7,123.2$, 122.5, 122.3, 121.0, 120.3, 110.8, 102.6, 75.8, 66.0, 43.8, 17.8, 13.3, -1.3. 
IR (Diamond-ATR, neat, $\mathrm{cm}^{-1}$ ) $\widetilde{v}_{\max }: 2951,2891,1532,1454,1426,1351,1351,1299,1248$, $1215,1070,834,736,714$.

Melting Point $\left({ }^{\circ} \mathrm{C}\right): 175-176$.

HRMS (DART) m/z [M+H] $]^{+}$calcd. for $\mathrm{C}_{25} \mathrm{H}_{32} \mathrm{~N}_{3} \mathrm{OSi}$ : 418.2309; Found: 418.2300.

Specific Rotation $[\alpha]^{23}{ }_{\mathrm{D}}:-44.8\left(\mathrm{c}=1.24, \mathrm{CHCl}_{3}\right)$.

Chiral SFC: Chiralcel AD-H (5:95 MeOH (0.1\% $\left.\mathrm{Et}_{2} \mathrm{NH}\right)$ :scCO2 to 20:80 $\mathrm{MeOH}(0.1 \%$ $\mathrm{Et}_{2} \mathrm{NH}$ ): $\mathrm{scCO} 2$ linear gradient over $20 \mathrm{~min}, 2.50 \mathrm{~mL} / \mathrm{min}$ ), $12.28 \mathrm{~min}$ (major), $11.19 \mathrm{~min}$ (minor). The absolute configuration was assigned by analogy to compound $\mathbf{1 3}$.

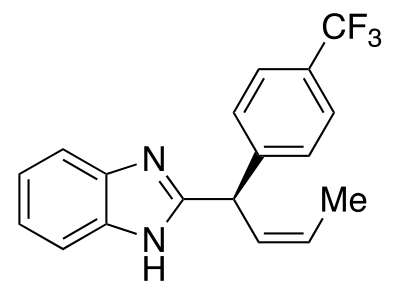

\section{(R,Z)-2-(1-(4-(trifluoromethyl)phenyl)but-2-en-1-yl)-1H-benzimidazole (19)}

Prepared according to General Procedure D using 1-( $p$-trifluoromethylphenyl)- $E$ butadiene (S8) (198 mg, $1.00 \mathrm{mmol}, 2.0$ equiv) and $1 H$-benzimidazol-1-yl pivalate (6) (109 mg, $0.500 \mathrm{mmol}, 1.0$ equiv). The crude material was purified by column chromatography ( $40 \mathrm{~g}$ silica, gradient: $350 \mathrm{~mL}$ of $5: 94: 1,250 \mathrm{~mL}$ of $15: 84: 1,250 \mathrm{~mL}$ of $20: 79: 1,500 \mathrm{~mL}$ of $25: 74: 1$, and 250 $\mathrm{mL}$ of 30:69:1, EtOAc:hexane:Et ${ }_{3} \mathrm{~N}$ ) to afford 19 as a colorless solid ( $1^{\text {st }}$ run: $123 \mathrm{mg}, 78 \%$ yield, 63:37 e.r., $2^{\text {nd }}$ run: $114 \mathrm{mg}, 72 \%$ yield, $63: 37$ e.r.).

${ }^{1} \mathbf{H}$ NMR $\left(\mathrm{CDCl}_{3}, 400 \mathrm{MHz}\right): \delta 7.56(\mathrm{~d}, J=7.7 \mathrm{~Hz}, 4 \mathrm{H}), 7.41(\mathrm{~d}, J=7.9 \mathrm{~Hz}, 2 \mathrm{H}), 7.25(\mathrm{~d}, J=9.1$ $\mathrm{Hz}, 2 \mathrm{H}), 6.05$ (t, $J=10.1 \mathrm{~Hz}, 1 \mathrm{H}), 5.93-5.81(\mathrm{~m}, 1 \mathrm{H}), 5.43(\mathrm{~d}, J=9.3 \mathrm{~Hz}, 1 \mathrm{H}), 1.76(\mathrm{dd}, J=6.9$, $1.8 \mathrm{~Hz}, 3 \mathrm{H})$.

${ }^{19} \mathbf{F}$ NMR $\left(\mathrm{CDCl}_{3}, 471 \mathrm{MHz}\right): \delta-62.58$.

${ }^{13} \mathbf{C ~ N M R}\left(\mathrm{CDCl}_{3}, 126 \mathrm{MHz}\right): \delta 154.5,144.8,129.9,129.7,128.9,128.5,128.0,126.1,126.1$, $125.3,123.1,43.5,13.4$.

IR (Diamond-ATR, neat, $\mathrm{cm}^{-1}$ ) $\tilde{v}_{\max }: 3057,2632,1619,1429,1326,1269,1133,1068,1018$, $818,739,599$.

Melting Point $\left({ }^{\circ} \mathrm{C}\right)$ : decomp. 161-162.

HRMS (DART) m/z [M+H] ${ }^{+}$calcd. for $\mathrm{C}_{18} \mathrm{H}_{16} \mathrm{~F}_{3} \mathrm{~N}_{2}$ : 317.1260; Found: 317.1266.

Specific Rotation $[\alpha]^{23}{ }_{\mathrm{D}}:-4.6\left(\mathrm{c}=1.11, \mathrm{CHCl}_{3}\right)$. 
Chiral SFC: Chiralcel OD-H (5:95 MeOH (0.1\% $\left.\mathrm{Et}_{2} \mathrm{NH}\right): \mathrm{scCO} 2$ to 20:80 $\mathrm{MeOH}(0.1 \%$ $\mathrm{Et}_{2} \mathrm{NH}$ ): $\mathrm{scCO} 2$ linear gradient over $20 \mathrm{~min}, 2.50 \mathrm{~mL} / \mathrm{min}$ ), $8.01 \mathrm{~min}$ (major), $7.24 \mathrm{~min}$ (minor). The absolute configuration was assigned by analogy to compound $\mathbf{1 3}$.<smiles>C/C=C\C(c1cccc(Br)c1)c1nc2ccc(Cl)cc2[nH]1</smiles>

\section{(R,Z)-2-(1-(3-bromophenyl)but-2-en-1-yl)-6-chloro-1H-benzimidazole (20)}

Prepared according to General Procedure D using 1-( $m$-bromophenyl)-E-butadiene (S7) $(158 \mu \mathrm{L}, 1.00 \mathrm{mmol}, 2.0$ equiv) and 6-chloro-1H-benzimidazol-1-yl pivalate (S4) (126 mg, 0.500 mmol, 1.0 equiv). The crude material was purified by column chromatography (40 g silica, gradient: $350 \mathrm{~mL}$ of 10:89:1, $350 \mathrm{~mL}$ of $15: 84: 1,500 \mathrm{~mL}$ of $20: 79: 1,250 \mathrm{~mL}$ of $25: 74: 1,250 \mathrm{~mL}$ of 30:69:1, and $350 \mathrm{~mL}$ of 35:64:1, EtOAc:hexane:Et ${ }_{3} \mathrm{~N}$ ) to afford $\mathbf{2 0}$ as a colorless solid ( ${ }^{\text {st }}$ run: $111 \mathrm{mg}, 61 \%$ yield, $51: 49$ e.r., $2^{\text {nd }}$ run: $128 \mathrm{mg}, 71 \%$ yield, $87: 13$ e.r.). A 50:50 mixture of tautomers was observed by ${ }^{1} \mathrm{H}$ NMR in $\mathrm{CDCl}_{3}$.

${ }^{1} \mathbf{H}$ NMR $\left(\mathrm{CDCl}_{3}, 500 \mathrm{MHz}\right)$ :

Major tautomer: $\delta 10.07(\mathrm{~s}, 1 \mathrm{H}), 7.55(\mathrm{~d}, J=8.6 \mathrm{~Hz}, 1 \mathrm{H}), 7.39-7.32(\mathrm{~m}, 2 \mathrm{H}), 7.29(\mathrm{~d}, J=2.0$ $\mathrm{Hz}, 1 \mathrm{H}), 7.18(\mathrm{dt}, J=8.8,1.7 \mathrm{~Hz}, 1 \mathrm{H}), 7.16-7.11(\mathrm{~m}, 2 \mathrm{H}), 5.96$ (dddd, $J=11.1,9.0,3.9,1.9 \mathrm{~Hz}$, $1 \mathrm{H}), 5.80(\mathrm{dq}, J=13.5,7.1 \mathrm{~Hz}, 1 \mathrm{H}), 5.21(\mathrm{~d}, J=9.3 \mathrm{~Hz}, 1 \mathrm{H}), 1.68(\mathrm{dt}, J=7.1,1.7 \mathrm{~Hz}, 3 \mathrm{H})$.

Minor tautomer: $\delta 9.95(\mathrm{~s}, 1 \mathrm{H}), 7.61(\mathrm{~d}, J=2.0 \mathrm{~Hz}, 1 \mathrm{H}), 7.39-7.32(\mathrm{~m}, 2 \mathrm{H}), 7.24(\mathrm{~d}, J=8.5 \mathrm{~Hz}$, $1 \mathrm{H}), 7.18(\mathrm{dt}, J=8.8,1.7 \mathrm{~Hz}, 1 \mathrm{H}), 7.16-7.11(\mathrm{~m}, 2 \mathrm{H}), 5.96$ (dddd, $J=11.1,9.0,3.9,1.9 \mathrm{~Hz}, 1 \mathrm{H})$, $5.80(\mathrm{dq}, J=13.5,7.1 \mathrm{~Hz}, 1 \mathrm{H}), 5.21$ (d, $J=9.3 \mathrm{~Hz}, 1 \mathrm{H}), 1.68(\mathrm{dt}, J=7.1,1.7 \mathrm{~Hz}, 3 \mathrm{H})$.

${ }^{13}$ C NMR $\left(\mathrm{CDCl}_{3}, 126 \mathrm{MHz}\right): \delta 156.5,156.0,144.1,142.9,141.8,134.4,132.4,131.0,130.7$, $130.7,128.5,128.1,126.7,123.5,123.2,123.1,120.3,119.3,111.7,111.0,43.4,13.4$.

IR (Diamond-ATR, neat, $\mathrm{cm}^{-1}$ ) $\widetilde{v}_{\max }: 2706,2359,1586,1470,1410,1268,1058,996,927,851$, 682.

Melting Point $\left({ }^{\circ} \mathrm{C}\right): 81-83$.

HRMS (DART) m/z [M+H] $]^{+}$calcd. for $\mathrm{C}_{17} \mathrm{H}_{15} \mathrm{BrClN}_{2}$ : 361.0102 ; Found: 361.0104 .

Specific Rotation $[\alpha]^{23}:-7.5\left(\mathrm{c}=1.09, \mathrm{CHCl}_{3}\right)$.

Chiral SFC: Chiralcel AD-H (5:95 MeOH (0.1\% $\left.\mathrm{Et}_{2} \mathrm{NH}\right): \mathrm{scCO} 2$ to 20:80 $\mathrm{MeOH}(0.1 \%$ $\mathrm{Et}_{2} \mathrm{NH}$ ):scCO2 linear gradient over $20 \mathrm{~min}, 2.50 \mathrm{~mL} / \mathrm{min}$ ), $13.86 \mathrm{~min}$ (major), $11.86 \mathrm{~min}$ (minor). The absolute configuration was assigned by analogy to compound $\mathbf{1 3}$.

Notes: Compound 20 exhibits tautomerization on the NMR timescale, with the compound in equilibrium with the chlorine in the 5 and 6 position. 


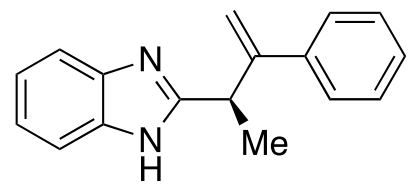

(R)-2-(3-phenylbut-3-en-2-yl)-1H-benzimidazole (21)

Prepared according to General Procedure D using 2-phenylbutadiene (S12) $(141 \mu \mathrm{L}$, $1.00 \mathrm{mmol}, 2.0$ equiv) and $1 H$-benzimidazol-1-yl pivalate (6) (109 mg, $0.500 \mathrm{mmol}, 1.0$ equiv). The crude material was purified by column chromatography $(40 \mathrm{~g}$ silica, gradient: $500 \mathrm{~mL}$ of $10: 89: 1,350 \mathrm{~mL}$ of $15: 84: 1,350 \mathrm{~mL}$ of $20: 79: 1,250 \mathrm{~mL}$ of $25: 74: 1,250 \mathrm{~mL}$ of $30: 69: 1$, and 250 $\mathrm{mL}$ of 35:64:1, EtOAc:hexane:Et ${ }_{3} \mathrm{~N}$ ) to afford 21 as a colorless solid ( $1^{\text {st }}$ run: $95 \mathrm{mg}, 77 \%$ yield, 95:5 e.r., $2^{\text {nd }}$ run: $90 \mathrm{mg}, 72 \%$ yield, $95: 5$ e.r.).

${ }^{1} \mathbf{H}$ NMR $\left(\mathrm{CDCl}_{3}, 500 \mathrm{MHz}\right): \delta 9.85(\mathrm{~s}, 1 \mathrm{H}), 7.73(\mathrm{~s}, 1 \mathrm{H}), 7.35-7.28(\mathrm{~m}, 3 \mathrm{H}), 7.26-7.22(\mathrm{~m}, 3 \mathrm{H})$, $7.20(\mathrm{~d}, J=5.5 \mathrm{~Hz}, 2 \mathrm{H}), 5.56(\mathrm{~s}, 1 \mathrm{H}), 5.31(\mathrm{~s}, 1 \mathrm{H}), 4.39(\mathrm{q}, J=7.2 \mathrm{~Hz}, 1 \mathrm{H}), 1.68(\mathrm{~d}, J=7.3 \mathrm{~Hz}$, $3 \mathrm{H})$.

${ }^{13} \mathbf{C}$ NMR $\left(\mathrm{CDCl}_{3}, 126 \mathrm{MHz}\right): \delta 156.9,149.7,143.5,140.2,133.8,128.7,128.1,126.5,122.7$, $122.1,119.4,114.8,110.8,39.7,19.1$.

IR (Diamond-ATR, neat, $\mathrm{cm}^{-1}$ ) $\widetilde{v}_{\max }: 2984,2742,2359,1623,1599,1493,1427,1327,1271$, 1239, 1108 1083, 978, 908, 737.

Melting Point $\left({ }^{\circ} \mathrm{C}\right): 181-182$.

HRMS (DART) m/z [M+H] ${ }^{+}$calcd. for $\mathrm{C}_{17} \mathrm{H}_{17} \mathrm{~N}_{2}$ : 249.1386; Found: 249.1387.

Specific Rotation $[\alpha]^{23}:+18.1\left(\mathrm{c}=0.80, \mathrm{CHCl}_{3}\right)$.

Chiral SFC: Chiralcel OD-H (5:95 MeOH (0.1\% $\left.\mathrm{Et}_{2} \mathrm{NH}\right): \mathrm{scCO} 2$ to $20: 80 \mathrm{MeOH}(0.1 \%$ $\mathrm{Et}_{2} \mathrm{NH}$ ): $\mathrm{scCO} 2$ linear gradient over $20 \mathrm{~min}, 2.50 \mathrm{~mL} / \mathrm{min}$ ), $11.15 \mathrm{~min}$ (major), $10.87 \mathrm{~min}$ (minor). The absolute configuration was assigned by analogy to $\mathrm{Li}$ et al. ${ }^{9}$<smiles>C=C(c1ccc(Cl)cc1)C(C)c1nc2ccccc2[nH]1</smiles>

(R)-2-(3-(4-chlorophenyl)but-3-en-2-yl)-1H-benzimidazole (22)

Prepared according to General Procedure D using 2-( $p$-chlorophenyl)-butadiene (S15) $(159 \mu \mathrm{L}, 1.00 \mathrm{mmol}, 2.0$ equiv) and $1 H$-benzimidazol-1-yl pivalate (6) (109 mg, $0.500 \mathrm{mmol}, 1.0$ equiv). The crude material was purified by column chromatography ( $40 \mathrm{~g}$ silica, gradient: 350 $\mathrm{mL}$ of $10: 89: 1,350 \mathrm{~mL}$ of 15:84:1, $500 \mathrm{~mL}$ of $20: 79: 1,500 \mathrm{~mL}$ of $25: 74: 1,250 \mathrm{~mL}$ of $27: 72: 1$, and $250 \mathrm{~mL}$ of $30: 69: 1$, EtOAc:hexane: $\left.\mathrm{Et}_{3} \mathrm{~N}\right)$ to obtain 22 as a solid ( $1^{\text {st }}$ run: $35 \%$ yield, $2^{\text {nd }}$ run: $45 \%$ yield, $3^{\text {rd }}$ run: $35 \%$ yield). The solid was then triturated with $1.5 \mathrm{~mL}$ of $\mathrm{MeCN}$, filtered, and dried under high vacuum to obtain analytically pure 22 as a colorless solid ( $1^{\text {st }}$ run: $15 \mathrm{mg}, 11 \%$ yield, 93:7 e.r., $2^{\text {nd }}$ run: $30 \mathrm{mg}, 21 \%$ yield, 94:6 e.r., $3^{\text {rd }}$ run $32 \mathrm{mg}, 23 \%$, 94:6 e.r.). 
${ }^{1} \mathbf{H}$ NMR $\left(\mathrm{CDCl}_{3}, 500 \mathrm{MHz}\right): \delta 8.84(\mathrm{~s}, 1 \mathrm{H}), 7.76(\mathrm{~d}, J=7.7 \mathrm{~Hz}, 1 \mathrm{H}), 7.35(\mathrm{dd}, J=7.7,1.6 \mathrm{~Hz}$, 1H), 7.29-7.19 (m, 6H), 5.60 (s, 1H), 5.39 (d, $J=1.2 \mathrm{~Hz}, 1 \mathrm{H}), 4.36$ (q, $J=7.0 \mathrm{~Hz}, 1 \mathrm{H}), 1.68$ (d, $J=7.1 \mathrm{~Hz}, 3 \mathrm{H})$.

${ }^{13} \mathrm{C}$ NMR $\left(\mathrm{CDCl}_{3}, 126 \mathrm{MHz}\right): \delta 156.1,148.2,138.3,134.2,128.9,128.8,127.9,127.9,123.1$, 115.4, 39.3, 18.9 .

IR (Diamond-ATR, neat, $\mathrm{cm}^{-1}$ ) $\widetilde{v}_{\text {max }}: 2962,1490,1429,1259,1092,1009,834,788,749$.

Melting Point $\left({ }^{\circ} \mathrm{C}\right)$ : decomp. $210-214$.

HRMS (DART) m/z [M+H] $]^{+}$calcd. for $\mathrm{C}_{17} \mathrm{H}_{16} \mathrm{ClN}_{2}$ : 283.0997; Found: 283.1001 .

Specific Rotation $[\alpha]^{23}{ }_{\mathrm{D}}:-8.2\left(\mathrm{c}=0.10, \mathrm{CHCl}_{3}\right)$.

Chiral SFC: Chiralcel AD-H (5:95 MeOH (0.1\% $\left.\mathrm{Et}_{2} \mathrm{NH}\right): \mathrm{scCO} 2$ to $20: 80 \mathrm{MeOH}(0.1 \%$ $\mathrm{Et}_{2} \mathrm{NH}$ ): $\mathrm{scCO} 2$ linear gradient over $20 \mathrm{~min}, 2.50 \mathrm{~mL} / \mathrm{min}$ ), $10.67 \mathrm{~min}$ (major), $11.78 \mathrm{~min}$ (minor). The absolute configuration was assigned by analogy to Li et al. ${ }^{9}$<smiles>C=C(c1nc2ccccc2[nH]1)C(C)C(=O)c1cn(C(C)(C)C)c2ccccc12</smiles>

tert-butyl $(R)-3-(3-(1 H$-benzimidazol-2-yl)but-1-en-2-yl)-1H-indole-1-carboxylate (23) Prepared according to General Procedure D using tert-butyl-3-(buta-1,3-dien-2-yl)-1Hindole-1-carboxylate (S14) $(269 \mathrm{mg}, 1.00 \mathrm{mmol}, 2.0$ equiv) and $1 H$-benzimidazol-1-yl pivalate (6) (109 $\mathrm{mg}, 0.500 \mathrm{mmol}, 1.0$ equiv). The crude material was purified by column chromatography (40 g silica, gradient: $250 \mathrm{~mL}$ of 10:89:1, $500 \mathrm{~mL}$ of 15:84:1, $500 \mathrm{~mL}$ of 20:79:1, and $500 \mathrm{~mL}$ of 25:74:1, EtOAc:hexane:Et $\left.{ }_{3} \mathrm{~N}\right)$ to afford $\mathbf{2 3}$ as a colorless solid ( $1^{\text {st }}$ run: $149 \mathrm{mg}, 77 \%$ yield, $96: 4$ e.r., $2^{\text {nd }}$ run: $142 \mathrm{mg}, 73 \%$ yield, $96: 4$ e.r.).

${ }^{1} \mathbf{H}$ NMR $\left(\mathrm{CDCl}_{3}, 500 \mathrm{MHz}\right): \delta 9.23(\mathrm{~s}, 1 \mathrm{H}), 8.17(\mathrm{~d}, J=8.3 \mathrm{~Hz}, 1 \mathrm{H}), 7.76(\mathrm{~d}, J=8.0 \mathrm{~Hz}, 2 \mathrm{H})$, 7.37-7.30 (m, 2H), 7.29-7.23 (m, 2H), $7.20(\mathrm{dd}, J=6.1,3.1 \mathrm{~Hz}, 2 \mathrm{H}), 5.76(\mathrm{~s}, 1 \mathrm{H}), 5.54(\mathrm{~s}, 1 \mathrm{H})$, $4.33(\mathrm{q}, J=7.1 \mathrm{~Hz}, 1 \mathrm{H}), 1.73(\mathrm{~d}, J=7.1 \mathrm{~Hz}, 3 \mathrm{H}), 1.54(\mathrm{~s}, 9 \mathrm{H})$.

${ }^{13} \mathrm{C}$ NMR $\left(\mathrm{CDCl}_{3}, 126 \mathrm{MHz}\right): \delta 156.6,149.5,143.5,142.2,135.9,133.5,129.0,124.8,123.7$, $123.1,122.5,120.3,120.1,119.6,115.5,115.1,110.7,84.1,41.1,28.4,28.2,18.7$.

IR (Diamond-ATR, neat, $\mathrm{cm}^{-1}$ ) $\widetilde{v}_{\max }: 2978,1732,1450,1366,1271,1240,1151,1060,902,852$, 739 ,

Melting Point $\left({ }^{\circ} \mathrm{C}\right): 143-148$.

HRMS (DART) m/z [M+H] $]^{+}$calcd. for $\mathrm{C}_{24} \mathrm{H}_{26} \mathrm{~N}_{3} \mathrm{O}_{2}$ : 388.2020; Found: 388.2015.

Specific Rotation $[\alpha]^{23}:-4.1\left(\mathrm{c}=1.02, \mathrm{CHCl}_{3}\right)$ 
Chiral SFC: Chiralcel AD-H (5:95 MeOH (0.1\% $\left.\mathrm{Et}_{2} \mathrm{NH}\right): \mathrm{scCO} 2$ to $20: 80 \mathrm{MeOH}(0.1 \%$ $\mathrm{Et}_{2} \mathrm{NH}$ ): $\mathrm{scCO} 2$ linear gradient over $20 \mathrm{~min}, 2.50 \mathrm{~mL} / \mathrm{min}$ ), $11.61 \mathrm{~min}$ (major), $10.39 \mathrm{~min}$ (minor). The absolute configuration was assigned by analogy to Li et al. ${ }^{9}$<smiles>C=C(c1ccccc1)C(C)c1nc2ccc(C(F)(F)F)cc2[nH]1</smiles>

\section{(R)-2-(3-phenylbut-3-en-2-yl)-6-(trifluoromethyl)-1 $H$-benzimidazole (24)}

Prepared according to General Procedure D using 2-phenylbutadiene (S12) $(141 \mu \mathrm{L}$, $1.00 \mathrm{mmol}, 2.0$ equiv) and 6-trifluoromethyl-1 $H$-benzimidazol-1-yl pivalate (S2) $(109 \mathrm{mg}, 0.500$ mmol, 1.0 equiv). The crude material was purified by column chromatography (40 g silica, gradient: $250 \mathrm{~mL}$ of 10:89:1, $500 \mathrm{~mL}$ of $15: 84: 1,500 \mathrm{~mL}$ of $20: 79: 1$, and $500 \mathrm{~mL}$ of $25: 74: 1$, EtOAc:hexane:Et ${ }_{3} \mathrm{~N}$ ), and dried under high vacuum at $45^{\circ} \mathrm{C}$ with sonication to obtain 24 as a colorless foam ( $1^{\text {st }}$ run: $71 \mathrm{mg}, 45 \%$ yield, 99:1 e.r., $2^{\text {nd }}$ run: $74 \mathrm{mg}, 47 \%$ yield, 99:1 e.r.). A 55:45 mixture of tautomers was observed by ${ }^{1} \mathrm{H}$ NMR in $\mathrm{CDCl}_{3}$.

${ }^{1} \mathbf{H}$ NMR $\left(\mathrm{CDCl}_{3}, 500 \mathrm{MHz}\right)$ :

Major tautomer: $\delta 9.59(\mathrm{~s}, 1 \mathrm{H}), 8.01(\mathrm{~s}, 1 \mathrm{H}), 7.46(\mathrm{~s}, 1 \mathrm{H}), 7.43-7.37(\mathrm{~m}, 1 \mathrm{H}), 7.35-7.29(\mathrm{~m}, 2 \mathrm{H})$, $7.28(\mathrm{dd}, J=4.9,2.2 \mathrm{~Hz}, 3 \mathrm{H}), 5.61(\mathrm{~s}, 1 \mathrm{H}), 5.34(\mathrm{~s}, 1 \mathrm{H}), 4.42(\mathrm{q}, J=7.1 \mathrm{~Hz}, 1 \mathrm{H}), 1.70(\mathrm{~d}, J=7.1$ $\mathrm{Hz}, 3 \mathrm{H})$.

Minor tautomer: $9.65(\mathrm{~s}, 1 \mathrm{H}), 7.78(\mathrm{~s}, 1 \mathrm{H}), 7.61(\mathrm{~s}, 1 \mathrm{H}), 7.47(\mathrm{~s}, 1 \mathrm{H}), 7.35-7.29(\mathrm{~m}, 2 \mathrm{H}), 7.28$ (dd, $J=4.9,2.2 \mathrm{~Hz}, 3 \mathrm{H}), 5.61(\mathrm{~s}, 1 \mathrm{H}), 5.34(\mathrm{~s}, 1 \mathrm{H}), 4.42(\mathrm{q}, J=7.1 \mathrm{~Hz}, 1 \mathrm{H}), 1.70(\mathrm{~d}, J=7.1 \mathrm{~Hz}$, $3 \mathrm{H})$.

${ }^{13} \mathrm{C} \mathrm{NMR}\left(\mathrm{CDCl}_{3}, 126 \mathrm{MHz}\right): \delta 159.6,158.9,149.2,145.7,143.0,139.9,135.7,133.1,128.8$, $128.3,126.4,123.8,119.8,119.3,117.1,115.1,111.0,108.4,39.7,18.9$.

${ }^{19}$ F NMR $\left.\mathrm{CDCl}_{3}, 471 \mathrm{MHz}\right): \delta-60.84$.

IR (Diamond-ATR, neat, $\mathrm{cm}^{-1}$ ) $\widetilde{v}_{\max }: 2979,2360,1629,1533,1419,1326,1158,1243,1111$, $1051,932$.

Melting Point $\left({ }^{\circ} \mathrm{C}\right):$ 93-95.

HRMS (DART) m/z [M+H] $]^{+}$calcd. for $\mathrm{C}_{18} \mathrm{H}_{16} \mathrm{~F}_{3} \mathrm{~N}_{2}$ : 317.1260; Found 317.1263.

Specific Rotation $[\alpha]^{23}$ : $+10.4\left(\mathrm{c}=0.25, \mathrm{CHCl}_{3}\right)$.

Chiral SFC: Chiralcel AD-H (5:95 MeOH (0.1\% $\left.\mathrm{Et}_{2} \mathrm{NH}\right)$ :scCO2 to 20:80 $\mathrm{MeOH}(0.1 \%$ $\mathrm{Et}_{2} \mathrm{NH}$ ): $\mathrm{scCO} 2$ linear gradient over $20 \mathrm{~min}, 2.50 \mathrm{~mL} / \mathrm{min}$ ), $6.67 \mathrm{~min}$ (major), $4.54 \mathrm{~min}$ (minor). The absolute configuration was assigned by analogy to Li et al. ${ }^{9}$ 
Notes: Compound 24 exhibits tautomerization on the NMR timescale, with the compound in equilibrium with the trifluoromethyl group in the 5 and 6 position.

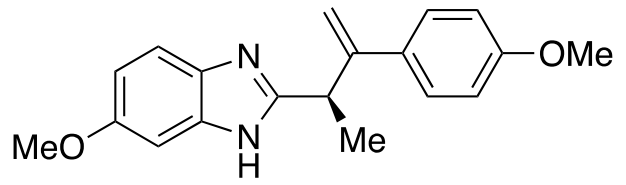

\section{(R)-6-methoxy-2-(3-(4-methoxyphenyl)but-3-en-2-yl)-1H-benzimidazole (25)}

Prepared according to General Procedure D using 2-( $p$-methoxyphenyl)-butadiene (S13)

$(172 \mu \mathrm{L}, 1.00 \mathrm{mmol}, 2.0$ equiv) and 6-methoxy-1H-benzimidazol-1-yl pivalate (S3) (124 mg, $0.500 \mathrm{mmol}, 1.0$ equiv). The crude material was purified by column chromatography ( $40 \mathrm{~g}$ silica, gradient: $350 \mathrm{~mL}$ of 10:89:1, $350 \mathrm{~mL}$ of $15: 84: 1,350 \mathrm{~mL}$ of $20: 79: 1,350 \mathrm{~mL}$ of $25: 74: 1,600 \mathrm{~mL}$ of 30:29:1, $250 \mathrm{~mL}$ of 32:27:1, and $250 \mathrm{~mL}$ of 33:26:1, EtOAc:hexane:Et ${ }_{3} \mathrm{~N}$ ) to afford 25 as a colorless solid ( $1^{\text {st }}$ run: $80 \mathrm{mg}, 52 \%$ yield, 94:6 e.r., $2^{\text {nd }}$ run: $65 \mathrm{mg}, 42 \%$ yield, 89:11 e.r.). A 50:50 mixture of tautomers was observed by ${ }^{1} \mathrm{H} \mathrm{NMR}$ in $\mathrm{CDCl}_{3}$.

${ }^{1} \mathbf{H}$ NMR $\left(\mathrm{CDCl}_{3}, 500 \mathrm{MHz}\right)$ :

Major tautomer: $\delta 9.52(\mathrm{~s}, 1 \mathrm{H}), 7.70-7.50(\mathrm{bs}, 1 \mathrm{H}), 7.27(\mathrm{~d}, J=8.9 \mathrm{~Hz}, 2 \mathrm{H}), 7.30-7.23(\mathrm{bs}, 1 \mathrm{H})$, $6.83(\mathrm{dd}, J=8.8,2.3 \mathrm{~Hz}, 1 \mathrm{H}), 6.80-6.76(\mathrm{~m}, 2 \mathrm{H}), 5.52(\mathrm{~s}, 1 \mathrm{H}), 5.26(\mathrm{~s}, 1 \mathrm{H}), 4.34(\mathrm{q}, J=7.1 \mathrm{~Hz}$, $1 \mathrm{H}), 3.81(\mathrm{~s}, 3 \mathrm{H}), 3.77(\mathrm{~s}, 3 \mathrm{H}), 1.68(\mathrm{~d}, J=7.1 \mathrm{~Hz}, 3 \mathrm{H})$.

Minor tautomer: $\delta 9.52(\mathrm{~s}, 1 \mathrm{H}), 7.27(\mathrm{~d}, J=8.9 \mathrm{~Hz}, 2 \mathrm{H}), 7.24-7.14(\mathrm{bs}, 1 \mathrm{H}), 6.83(\mathrm{dd}, J=8.8$, $2.3 \mathrm{~Hz}, 1 \mathrm{H}), 6.86-6.76(\mathrm{bs}, 1 \mathrm{H}), 6.80-6.76(\mathrm{~m}, 2 \mathrm{H}), 5.52(\mathrm{~s}, 1 \mathrm{H}), 5.26(\mathrm{~s}, 1 \mathrm{H}), 4.34(\mathrm{q}, J=7.1$ $\mathrm{Hz}, 1 \mathrm{H}), 3.81(\mathrm{~s}, 3 \mathrm{H}), 3.77(\mathrm{~s}, 3 \mathrm{H}), 1.68(\mathrm{~d}, J=7.1 \mathrm{~Hz}, 3 \mathrm{H})$.

${ }^{13} \mathbf{C ~ N M R}\left(\mathrm{CDCl}_{3}, 126 \mathrm{MHz}\right): \delta 159.5,156.4,155.9,148.9,134.3,132.4,127.7,119.9,114.0$, $113.1,111.0,102.0,94.6,55.9,55.4,39.7,19.0$.

IR (Diamond-ATR, neat, $\mathrm{cm}^{-1}$ ) $\widetilde{v}_{\max }: 2934,2833,2360,2343,1627,1606,1510,1451,1414$, 1243, 1153, 1028, 832, 803, 750 .

HRMS (DART) m/z [M+H] ${ }^{+}$calcd. for $\mathrm{C}_{19} \mathrm{H}_{21} \mathrm{~N}_{2} \mathrm{O}_{2}: 309.1598$, Found: 309.1592.

Melting Point $\left({ }^{\circ} \mathrm{C}\right)$ : decomp. 205-210.

Specific Rotation $[\alpha]^{23}:+26.8\left(\mathrm{c}=0.25, \mathrm{CHCl}_{3}\right)$.

Chiral SFC: Chiralcel AD-H (5:95 MeOH (0.1\% $\left.\mathrm{Et}_{2} \mathrm{NH}\right): \mathrm{scCO} 2$ to 20:80 $\mathrm{MeOH}(0.1 \%$ $\mathrm{Et}_{2} \mathrm{NH}$ ): $\mathrm{scCO} 2$ linear gradient over $20 \mathrm{~min}, 2.50 \mathrm{~mL} / \mathrm{min}$ ), $12.81 \mathrm{~min}$ (major), $15.08 \mathrm{~min}$ (minor). The absolute configuration was assigned by analogy to Li et al. ${ }^{9}$

Notes: Compound 25 exhibits tautomerization on the NMR timescale, with the compound in equilibrium with the methoxy group in the 5 and 6 position. 


\subsection{Synthesis of 11 on a $1.0 \mathrm{mmol}$ Scale}

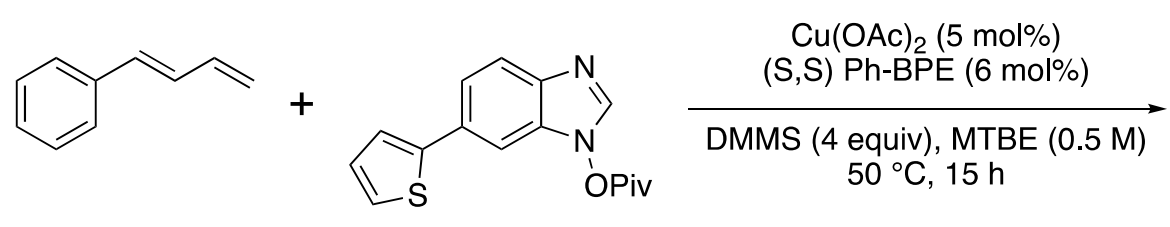

DMMS (4 equiv), MTBE (0.5 M)

$50^{\circ} \mathrm{C}, 15 \mathrm{~h}$

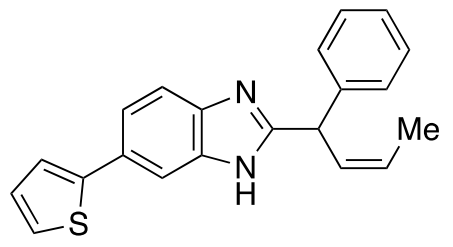

11

Run 1: $76 \%$

Run 2: $74 \%$

96:4 e.r.

\section{Procedure:}

Inside a nitrogen filled glovebox, an oven-dried reaction tube (Fisherbrand, 20x125 mm, 1495937A) equipped with a magnetic stir bar was charged with $\mathrm{Cu}(\mathrm{OAc})_{2}(9.0 \mathrm{mg}, 50.0 \mu \mathrm{mol}, 5$ mol\%), $(S, S)-P h-B P E ~(30.4 \mathrm{mg}, 60.0 \mu \mathrm{mol}, 6 \mathrm{~mol} \%)$ and methyl tert-butyl ether $(2 \mathrm{~mL})$. This solution was capped with a screw cap containing a PTFE septum and allowed to stir for $10 \mathrm{~min}$. The cap was removed and dimethoxy(methyl)silane ( $490 \mu \mathrm{L}, 2.00 \mathrm{mmol}, 4.0$ equiv) was added by pipette.

After stirring for $15 \mathrm{~min}$, the cap was removed and 1-phenyl- $E$-butadiene (7) $(280 \mu \mathrm{L}, 2.00$ mmol, 2.0 equiv) was added to the reaction tube via pipette. The reaction tube was capped and the reaction mixture was allowed to stir for $10 \mathrm{~min}$, then the cap was removed and 6-(thiophen-2-yl)$1 H$-benzimidazol-1-yl pivalate (S5) was added (300 mg, $1.00 \mathrm{mmol}, 1.0$ equiv). The reaction tube was once again capped, removed from the glovebox and placed in an oil bath preheated to $50{ }^{\circ} \mathrm{C}$.

After the reaction mixture had stirred for $15 \mathrm{~h}$ at $50{ }^{\circ} \mathrm{C}$, the reaction tube was removed from the oil bath and allowed to cool to rt. Once at $\mathrm{rt}$, the cap was removed from the reaction tube and the reaction mixture was quenched by the addition of sat. $\mathrm{NH}_{4} \mathrm{~F}$ in $\mathrm{MeOH}(10 \mathrm{~mL})$ and allowed to stir $5 \mathrm{~min}$. The reaction mixture was then transferred into a separatory funnel containing sat. aq. $\mathrm{NaHCO}_{3}(20 \mathrm{~mL})$, and the tube was rinsed with EtOAc $(20 \mathrm{~mL})$. The phases were separated, and the aq. phase was extracted with EtOAc $(2 \times 30 \mathrm{~mL})$. The combined organic layers were dried over $\mathrm{Na}_{2} \mathrm{SO}_{4}$, filtered through a fritted glass funnel, and concentrated in vacuo with the aid of a rotary evaporator.

The resultant crude material was dissolved in $\mathrm{CH}_{2} \mathrm{Cl}_{2}(2 \mathrm{~mL})$ and purified by column chromatography (70 g silica, gradient: $500 \mathrm{~mL}$ of 10:89:1, $500 \mathrm{~mL}$ of 20:79:1, $500 \mathrm{~mL}$ of 30:69:1, and $500 \mathrm{~mL}$ of 35:64:1, EtOAc:hexane:Et ${ }_{3} \mathrm{~N}$ ) to afford 11 as a colorless solid (1 ${ }^{\text {st }}$ run: $250 \mathrm{mg}, 76 \%$ yield, 96:4 e.r., $2^{\text {nd }}$ run: $245 \mathrm{mg}, 74 \%$ yield, 95:5 e.r.). 


\section{Single Crystal X-Ray Diffraction Data}

\subsection{Crystal Growth and Refinement Procedure:}

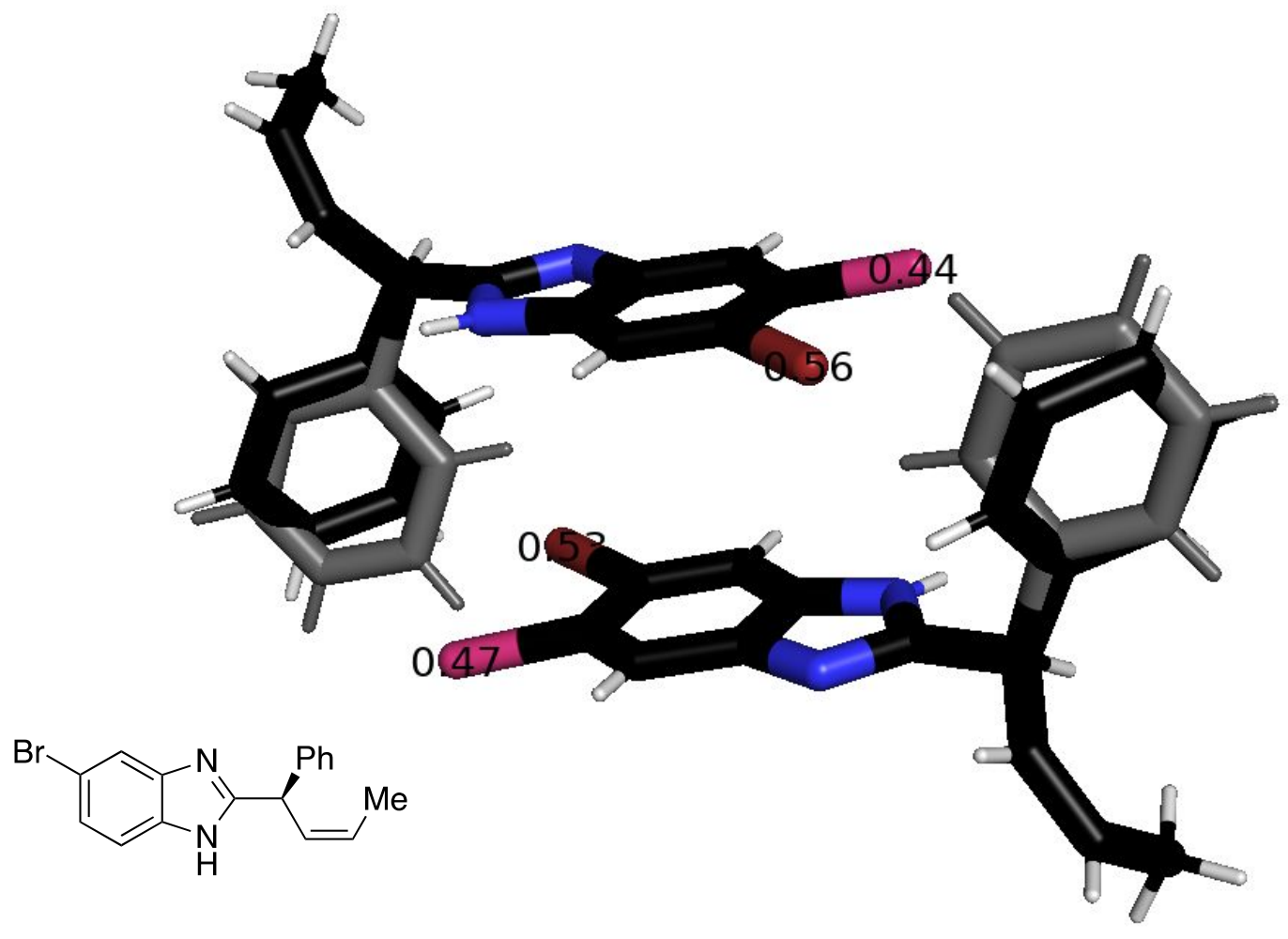

$10 \mathrm{mg}$ of $(R, Z)$-5-bromo-2-(1-phenylbut-2-en-1-yl)-1H-benzimidazole (13) was dissolved in $0.5 \mathrm{~mL}$ of THF in a $1 \mathrm{dram}$ vial. The vial was capped and sonicated for $5 \mathrm{~min}$ at $\mathrm{rt}$. The resulting solution was taken up in a syringe, and filtered through a 0.4 micron PTFE syringe filter into a new clean 1 dram vial without a cap. Using forceps, this vial was placed in a 4 dram vial containing hexane, and the 4 dram vial was capped. The entire setup was then placed in a freezer at $-5{ }^{\circ} \mathrm{C}$. The crystals were allowed to grow by vapor diffusion over one week.

Low-temperature diffraction data ( $\varphi$-and $\omega$-scans) were collected on a Bruker D8 Venture diffractometer equipped with an Incoatec microfocus $3.0(\mathrm{Cu})$ source $(\lambda=1.54178 \AA)$. Data reduction was performed with the program SAINT. ${ }^{11}$ Absorption correction and scaling were performed with the program SADABS. ${ }^{12}$ The structure was solved by direct methods using SHELXT $^{13}$ and refined against F2 on all data by full-matrix least squares with SHELXL, ${ }^{14}$ following established refinement strategies. ${ }^{15}$ All non-hydrogen atoms were refined anisotropically. The hydrogen atom attached to N1 was found in the difference Fourier map and refined semi-freely. All other hydrogen atoms were included into the model at geometrically calculated positions and refined using a riding model. The isotropic displacement parameters of all hydrogen atoms were constrained to 1.2 times the Ueq value of the atoms they are bonded to (1.5 times for methyl groups). Disordered solvent molecules were accounted for utilizing SQUEEZE. ${ }^{16}$

The compound crystallized in the R3 space group, with two molecules in the asymmetric unit, which were found to be disordered in the positional placement of the bromine atoms (at the C5 and C6 positions). Additionally, the phenyl substituents were found to be rotationally disordered, with two distinct conformations visible in the difference Fourier map. There is a pi- 
stacking interaction between the bromine atom of molecule 1 and the phenyl ring of molecule 2 . This interaction appears coupled to the positional disorder of the bromine, and so these were refined together, having the same part numbers in shellxl, and refined such that the sum of both components was 1.00 . The bromine in molecule one was found to have positional disorder between $\mathrm{C} 5: \mathrm{C} 6$ in a 56:44 ratio, in molecule two it was found to be 53:47. Rigid bond restraints, as well as similarity restraints on displacement parameters were applied. The benzimidazole rings were restrained to be flat, as were the phenyl rings.

\subsection{Crystal Data and Structure Refinement Details}

Empirical formula

Identification code

Formula weight

Temperature

Wavelength

Crystal system

Space group

Unit cell dimensions:

Volume

Z

Absorption coefficient:

$\mathrm{F}(000)$ :

Theta range for data collection:

Index ranges:

Reflections collected:

Independent reflections:

Completeness to theta $=67.679^{\circ}$

Absorption correction:

Max. and min. transmission:

Refinement method:

Data / restraints / parameters:

Goodness-of-fit on F2:

Final R indices $[\mathrm{I}>2 \sigma(\mathrm{I})]$ :

$\mathrm{R}$ indices (all data):

Largest diff. peak and hole:
$\mathrm{C}_{17} \mathrm{H}_{15} \mathrm{Br} \mathrm{N} \mathrm{N}_{2}$

P8_20013

327.22

100(2) K

$1.54178 \AA$

Trigonal

R3

$$
\begin{array}{ll}
\mathrm{a}=24.4004(3) \AA & \alpha=90^{\circ} \\
\mathrm{b}=24.4004(3) \AA & \beta=90^{\circ} \\
\mathrm{c}=14.6467(3) \AA & \gamma=120^{\circ}
\end{array}
$$

7552(02) $\AA^{3}$

2

$4.349 \mathrm{~mm}^{-1}$

3984

3.623 to $70.183^{\circ}$

$-29=<\mathrm{h}=<29, \quad-29=<\mathrm{k}=<29, \quad-17=<1=<17$

29577

$6361[$ Rint $=0.0448]$

$100.0 \%$

Spherical

0.22438 and 0.1109

Full-matrix least-squares on F2

6361 / 1067 / 497

1.082

$\mathrm{R} 1=0.0480, \mathrm{wR} 2=0.1354$

$\mathrm{R} 1=0.0510 \mathrm{wR} 2=0.1378$

0.599 and -0.627 e. $\AA^{-3}$ 


\section{Supporting Information}

\subsection{Thermal Ellipsoid Plot}

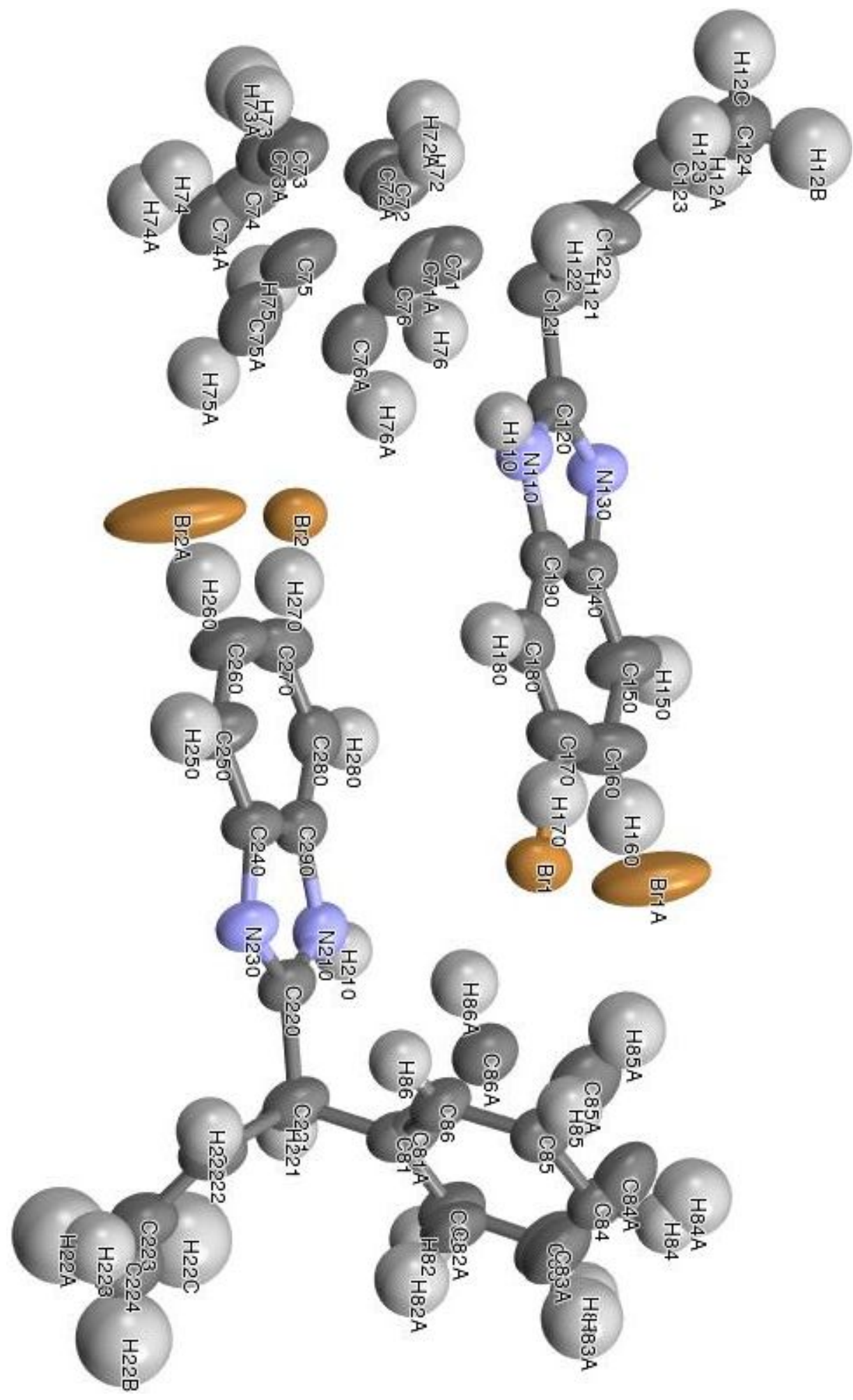

Thermal ellipsoid plot of asymmetric unit at 50\% probability and $100 \mathrm{~K}$. 


\section{References and Notes}

1. National Research Council. 2011. "Prudent Practices in the Laboratory: Handling and Management of Chemical Hazards, Updated Version”, Washington, DC: The National Academies Press; doi: 10.17226/12654.

2. Ansari, N. H.; Jordan, A. L.; Söderberg, B. C. G. A Facile Base-Mediated Synthesis of N-Alkoxy-Substituted Benzimidazoles. Tetrahedron 2017, 73, 4811-4821.

3. Jiang, B.; Liang, Q.-J.; Han, Y.; Zhao, M.; Xu, Y.-H.; Loh, T.-P. Copper-Catalyzed Dehydrogenative Diels-Alder Reaction. Org. Lett. 2018, 20, 3215-3219.

4. Lebel, H.; Paquet, V. Catalytic Activity of a New Ruthenium-(Trimethylsilyl)Diazomethane Complex. Organometallics 2004, 23, 1187 1190.

5. Jiang, B.; Liang, Q.-J.; Han, Y.; Zhao, M.; Xu, Y.-H.; Loh, T.-P. Copper-Catalyzed Dehydrogenative Diels-Alder Reaction. Org. Lett. 2018, 20, 3215-3219.

6. Lebel, H.; Paquet, V. Catalytic Activity of a New Ruthenium-(Trimethylsilyl)Diazomethane Complex. Organometallics 2004, 23, 1187 1190.

7. Wang, T.; Hu, Y.; Zhang, S. A Novel and Efficient Method for the Olefination of Carbonyl Compounds with Grignard Reagents in the Presence of Diethyl Phosphite. Org. Biomol. Chem. 2010, 8, 2312-2315.

8. Preuß, T.; Saak, W.; Doye, S. Titanium-Catalyzed Intermolecular Hydroaminoalkylation of Conjugated Dienes. Chem. Eur. J. 2013, 19, 3833-3837.

9. Fiorito, D.; Folliet, S.; Liu, Y.; Mazet, C. A General Nickel-Catalyzed Kumada Vinylation for the Preparation of 2-Substituted 1,3-Dienes. ACS Catal. 2018, 8, 13921398.

10. Li, C.; Shin, K.; Liu, R. Y.; Buchwald, S. L. Engaging Aldehydes in CuH-Catalyzed Reductive Coupling Reactions: Stereoselective Allylation with Unactivated 1,3-Diene Pronucleophiles. Angew. Chem. Int. Ed. 2019, 58, 17074-17080.

11. SAINT (V8.40A), Bruker AXS Inc., Madison, Wisconsin, USA, 2012.

12. L. Krause, R. Herbst-Irmer, G. M. Sheldrick and D. Stalke, J. Appl. Cryst. 2015, 48, 310.

13. Sheldrick, G. M. SHELXT-Integrated Space-Group and Crystal-Structure Determination. Acta Cryst. A 2015, 71, 3-8.

14. Sheldrick, G. M. Crystal Structure Refinement with SHELXL. Acta Cryst. C 2015, 71, $3-$ 8.

15. Müller, P. Practical Suggestions for Better Crystal Structures. Crystallogr. Rev. 2009, 15, 57-83.

16. Spek, A. L. PLATON SQUEEZE: A Tool for the Calculation of the Disordered Solvent Contribution to the Calculated Structure Factors. Acta Cryst. C 2015, 71, 9-18. 


\section{7: Associated Analytical Data}

\section{1: NMR Spectra of Products and Starting Materials}

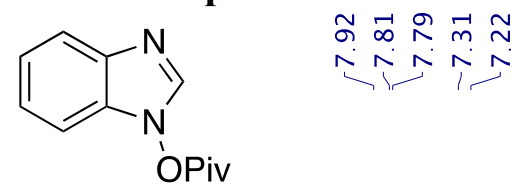

6

${ }^{1} \mathrm{H}$ NMR

$\mathrm{CDCl}_{3}, 400 \mathrm{MHz}$

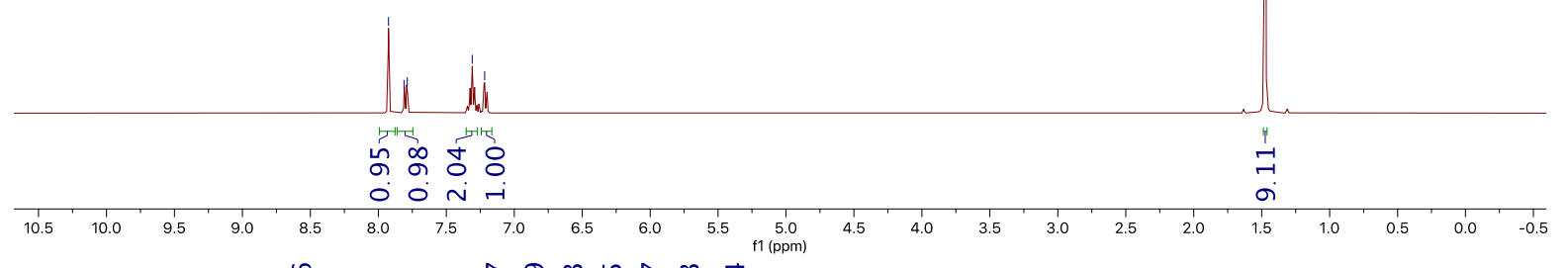

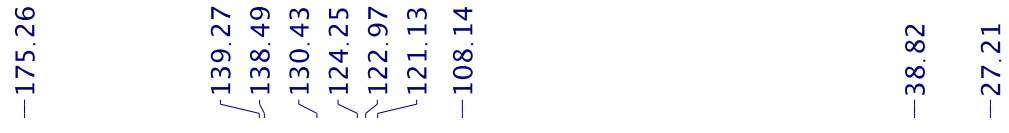

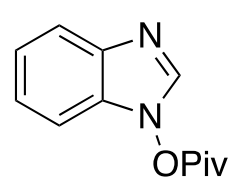

6

${ }^{13} \mathrm{C}$ NMR

$\mathrm{CDCl}_{3}, 126 \mathrm{MHz}$
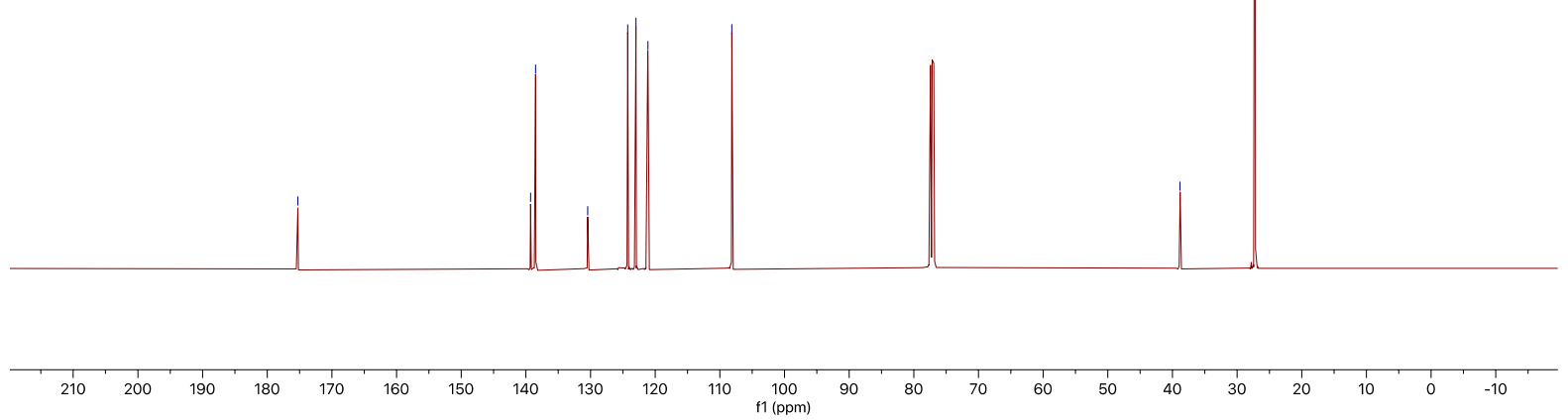
Supporting Information

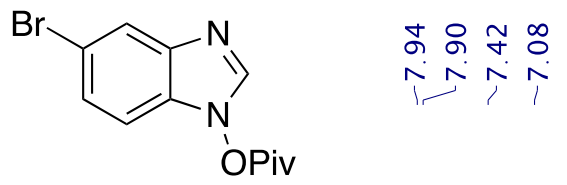

S1

${ }^{1} \mathrm{H}$ NMR

$\mathrm{CDCl}_{3}, 400 \mathrm{MHz}$

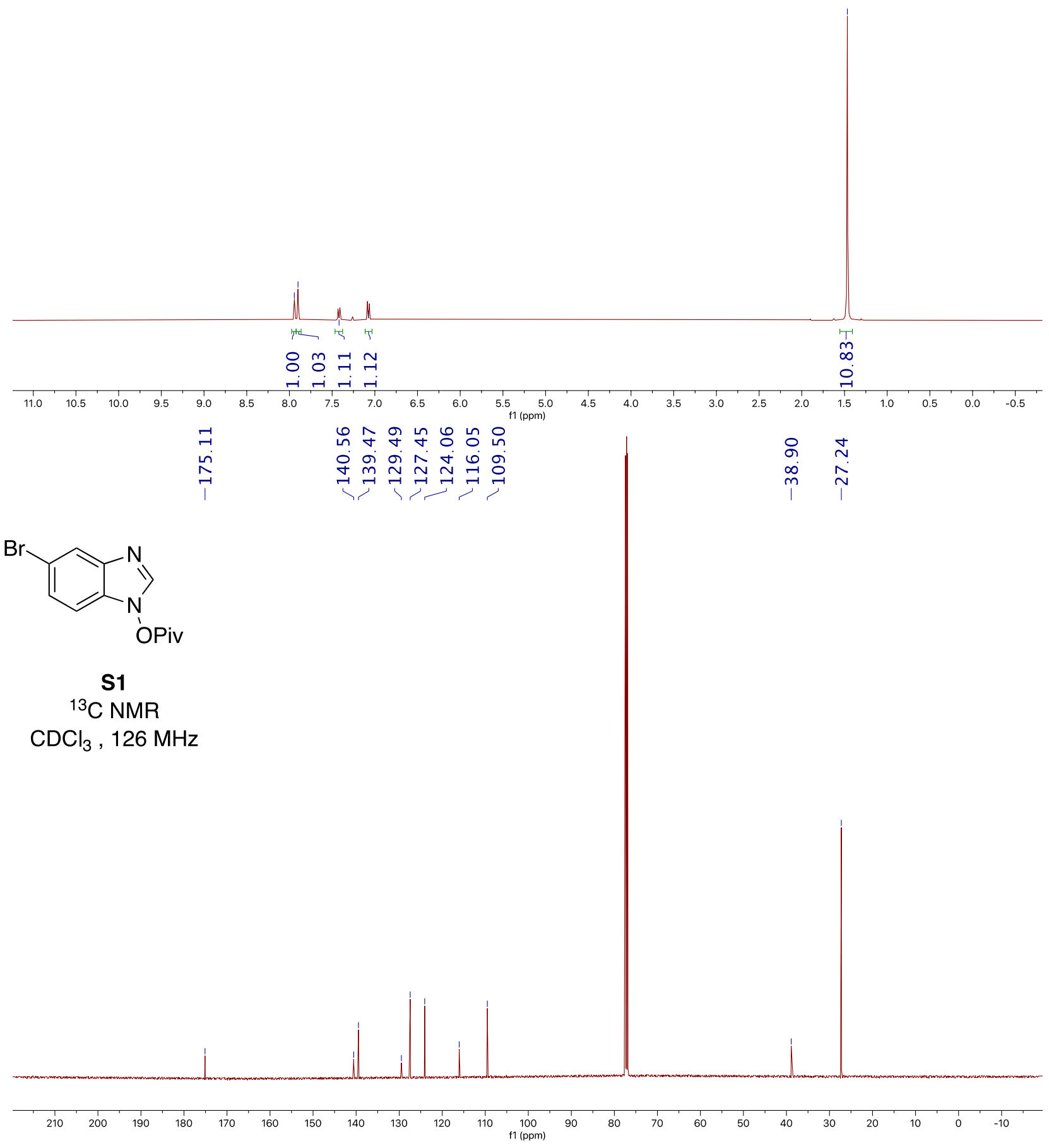




\section{Supporting Information}

$\overbrace{\text { OPiv }}^{N} \overbrace{\substack{N \\ N}}^{N}$

S2

${ }^{1} \mathrm{H}$ NMR

$\mathrm{CDCl}_{3}, 500 \mathrm{MHz}$

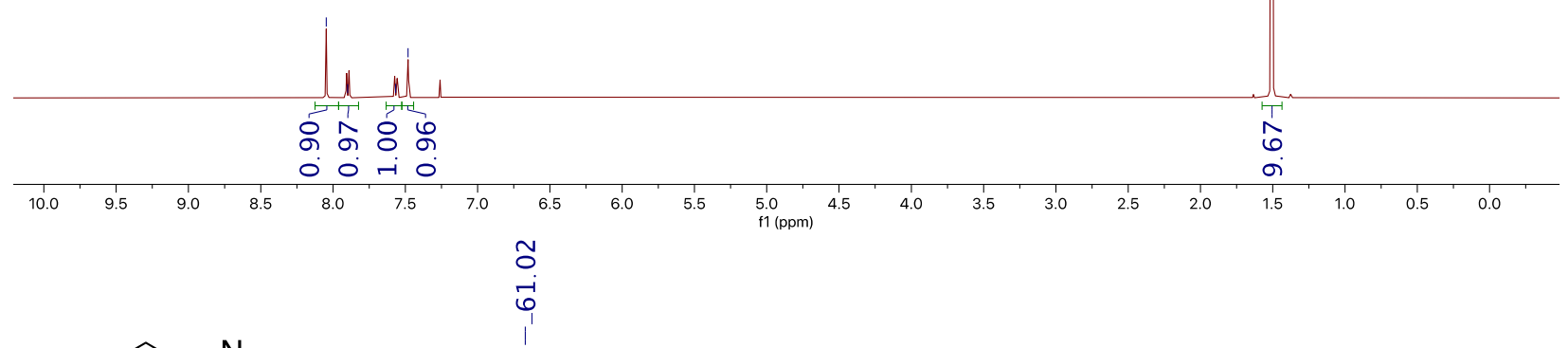<smiles>FC(F)(F)c1ccc2ncn(O[AlH2])c2c1</smiles>

S2

${ }^{19} \mathrm{~F} \mathrm{NMR}$

$\mathrm{CDCl}_{3}, 471 \mathrm{MHz}$

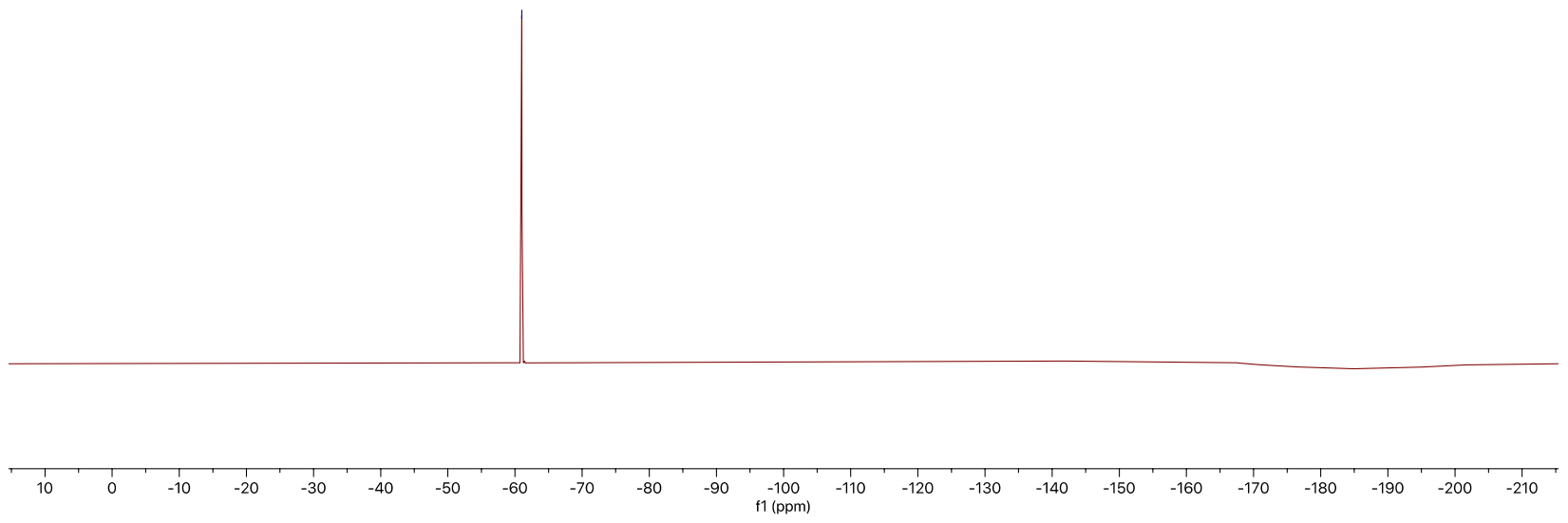


Supporting Information

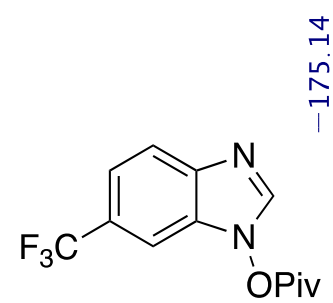

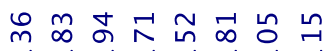

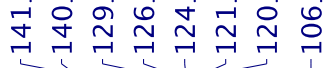

S2

${ }^{13} \mathrm{C}$ NMR

$\mathrm{CDCl}_{3}, 126 \mathrm{MHz}$

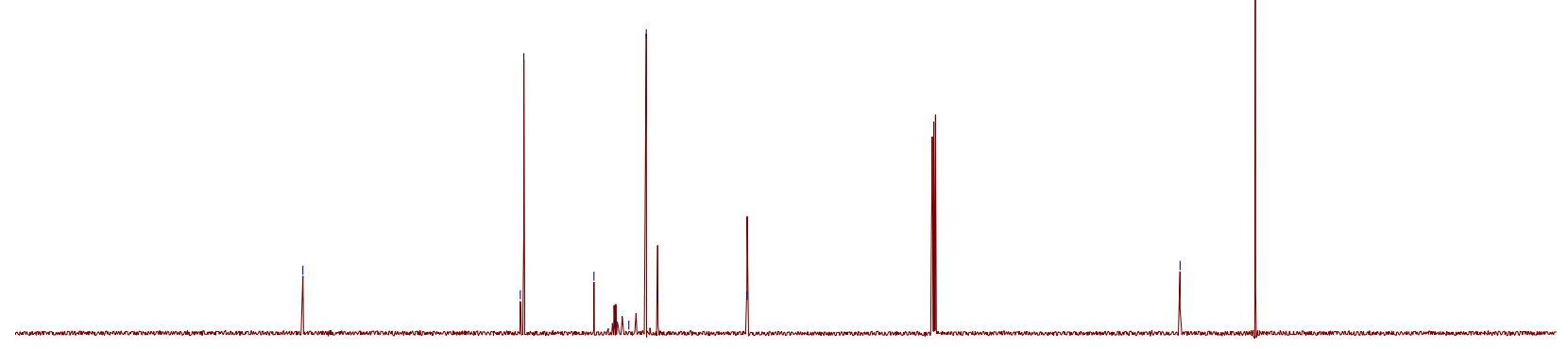

$\begin{array}{lllllllllllllllllllllllllllll}210 & 200 & 190 & 180 & 170 & 160 & 150 & 140 & 130 & 120 & 110 & 100 & 90 & 80 & 70 & 60 & 50 & 40 & 30 & 20 & 10 & 0 & -10 & 10\end{array}$ 
Supporting Information

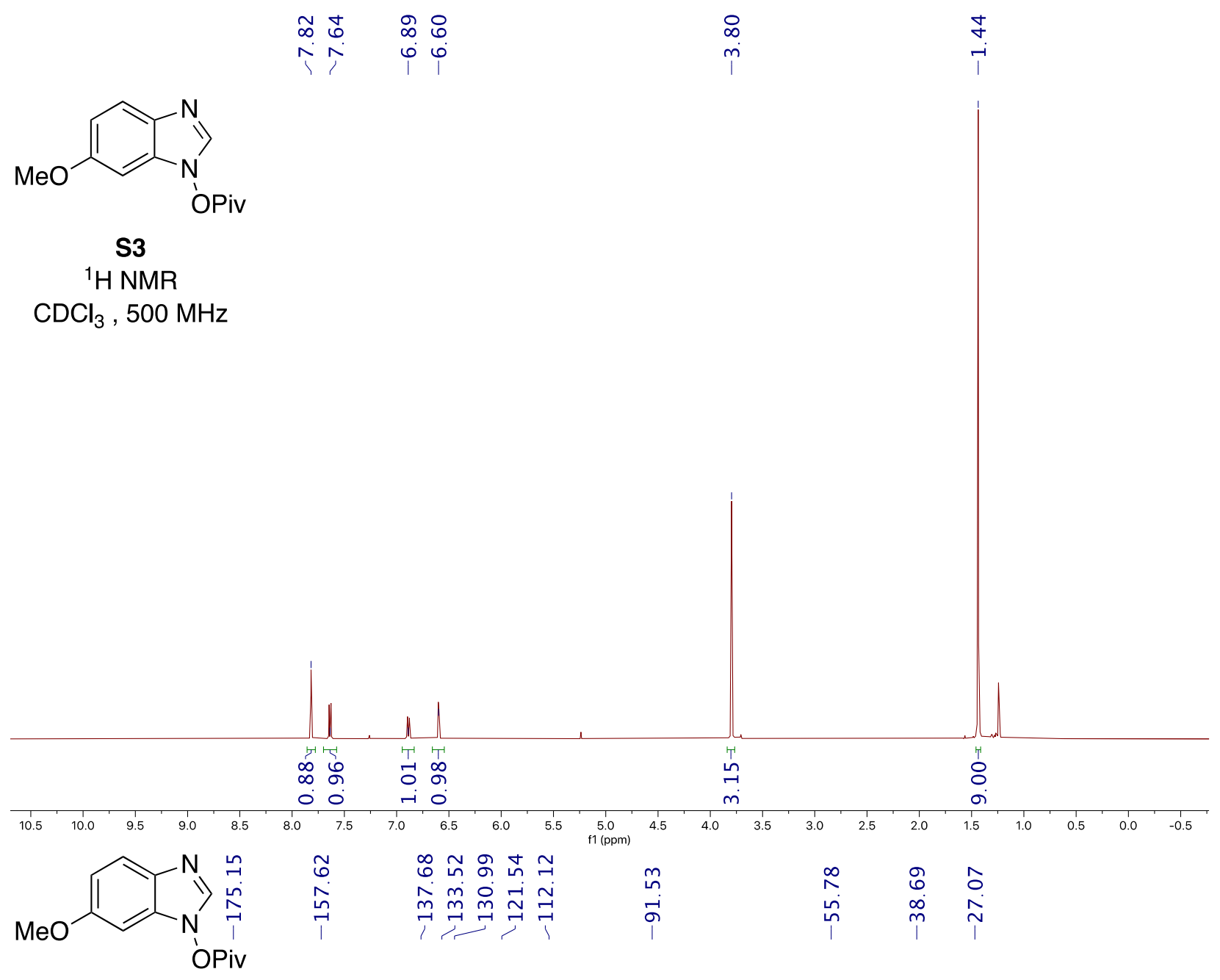

S3

${ }^{13} \mathrm{C}$ NMR

$\mathrm{CDCl}_{3}, 126 \mathrm{MHz}$

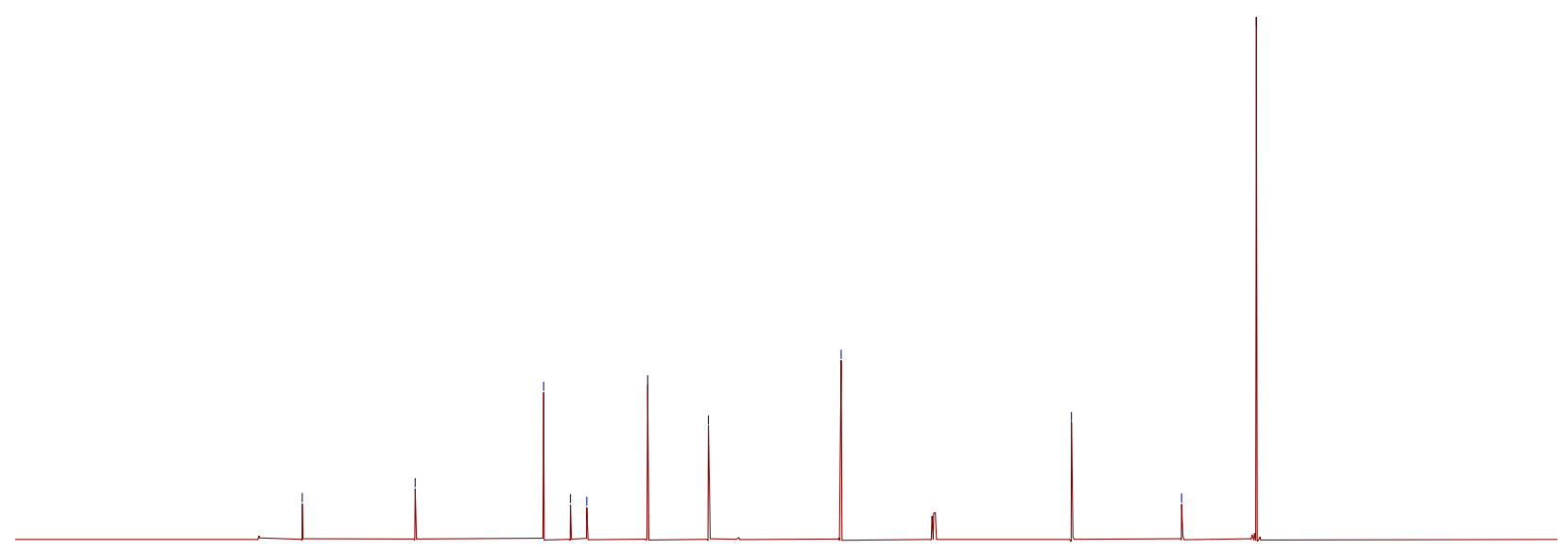

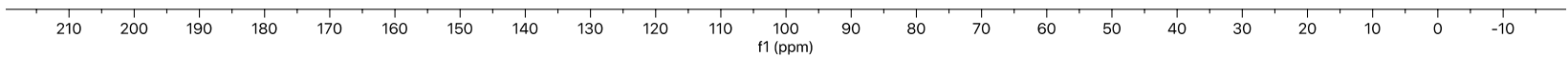


Supporting Information

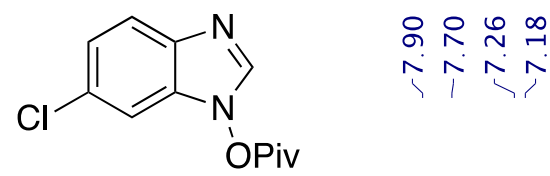

S4

${ }^{1} \mathrm{H}$ NMR

$\mathrm{CDCl}_{3}, 400 \mathrm{MHz}$

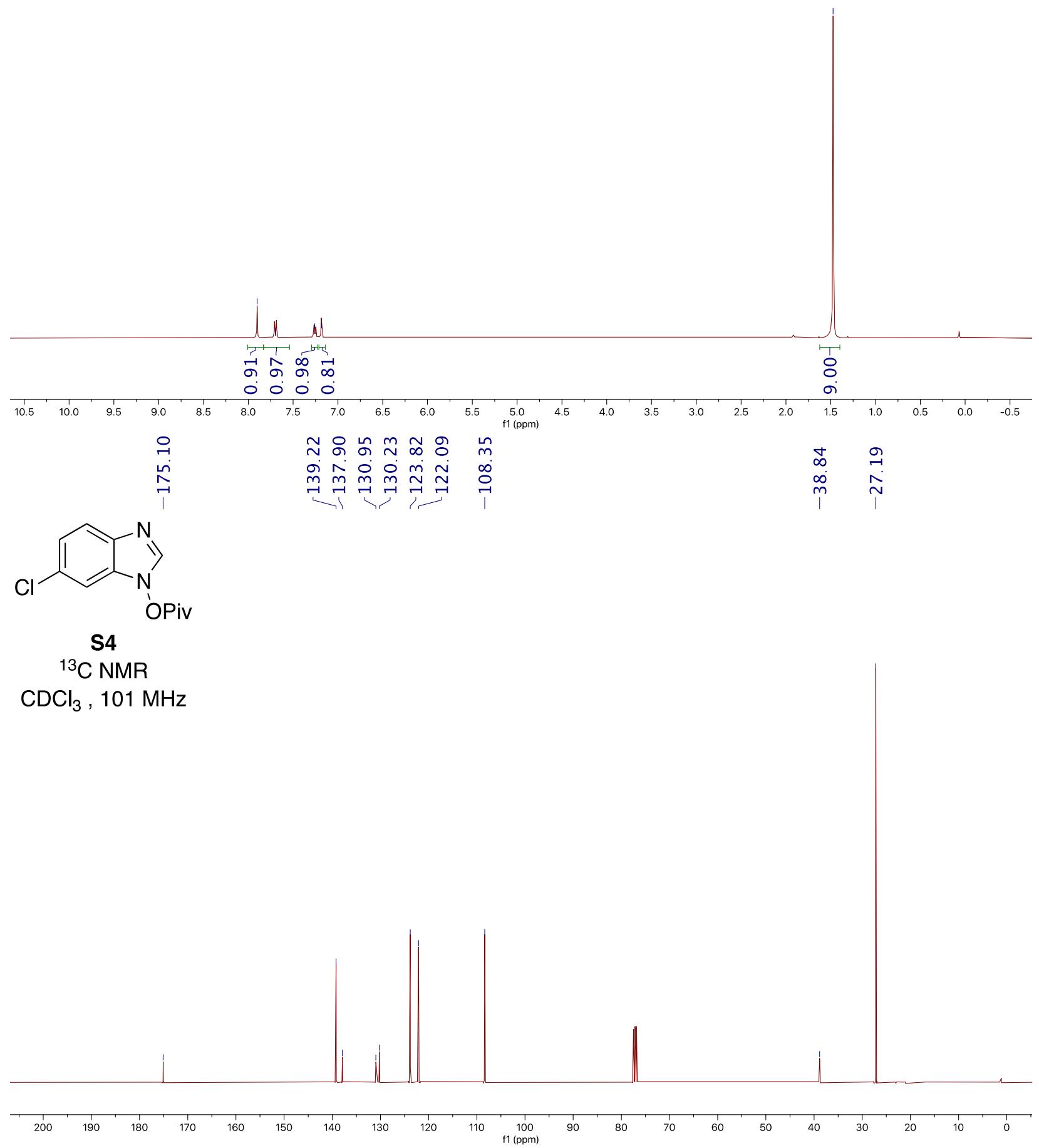




\section{Supporting Information}

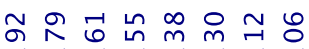

$N N N N N N N$

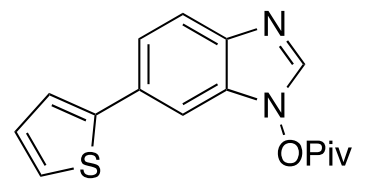

S5

${ }^{1} \mathrm{H}$ NMR

$\mathrm{CDCl}_{3}, 400 \mathrm{MHz}$

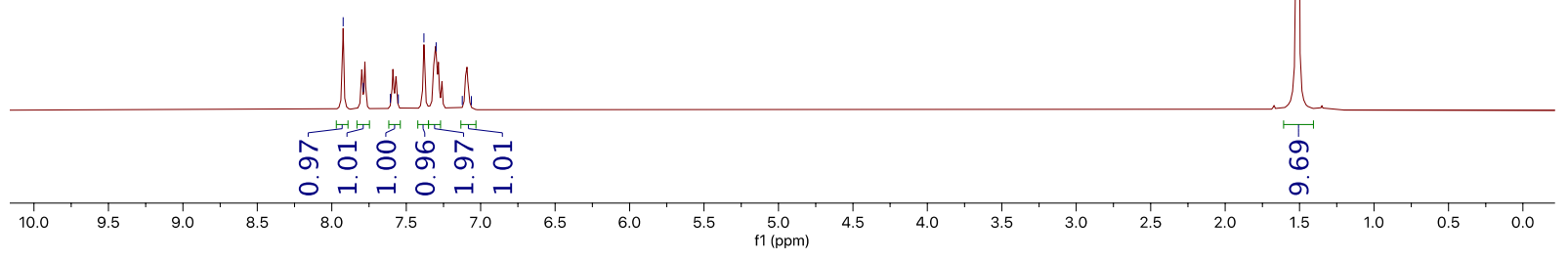

$\stackrel{\infty}{\sim}$ ㅇำน 능

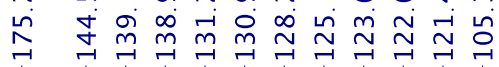

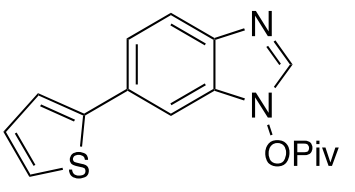

S5

${ }^{13} \mathrm{C}$ NMR

$\mathrm{CDCl}_{3}, 126 \mathrm{MHz}$

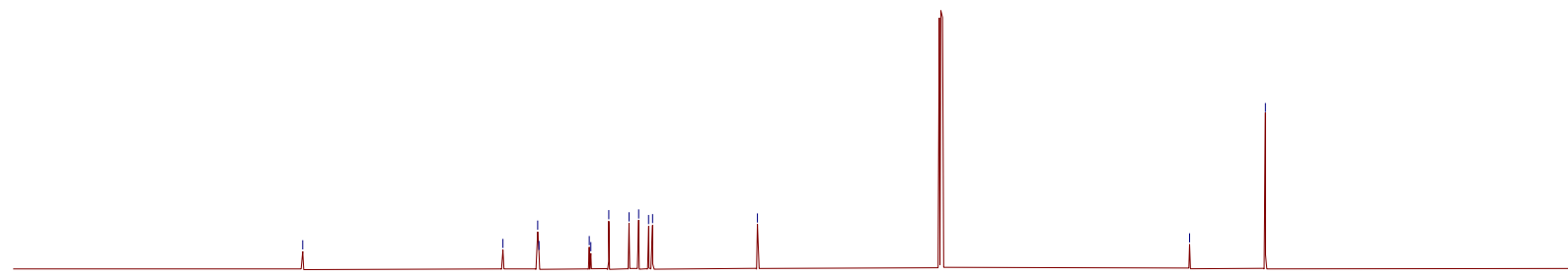


Supporting Information

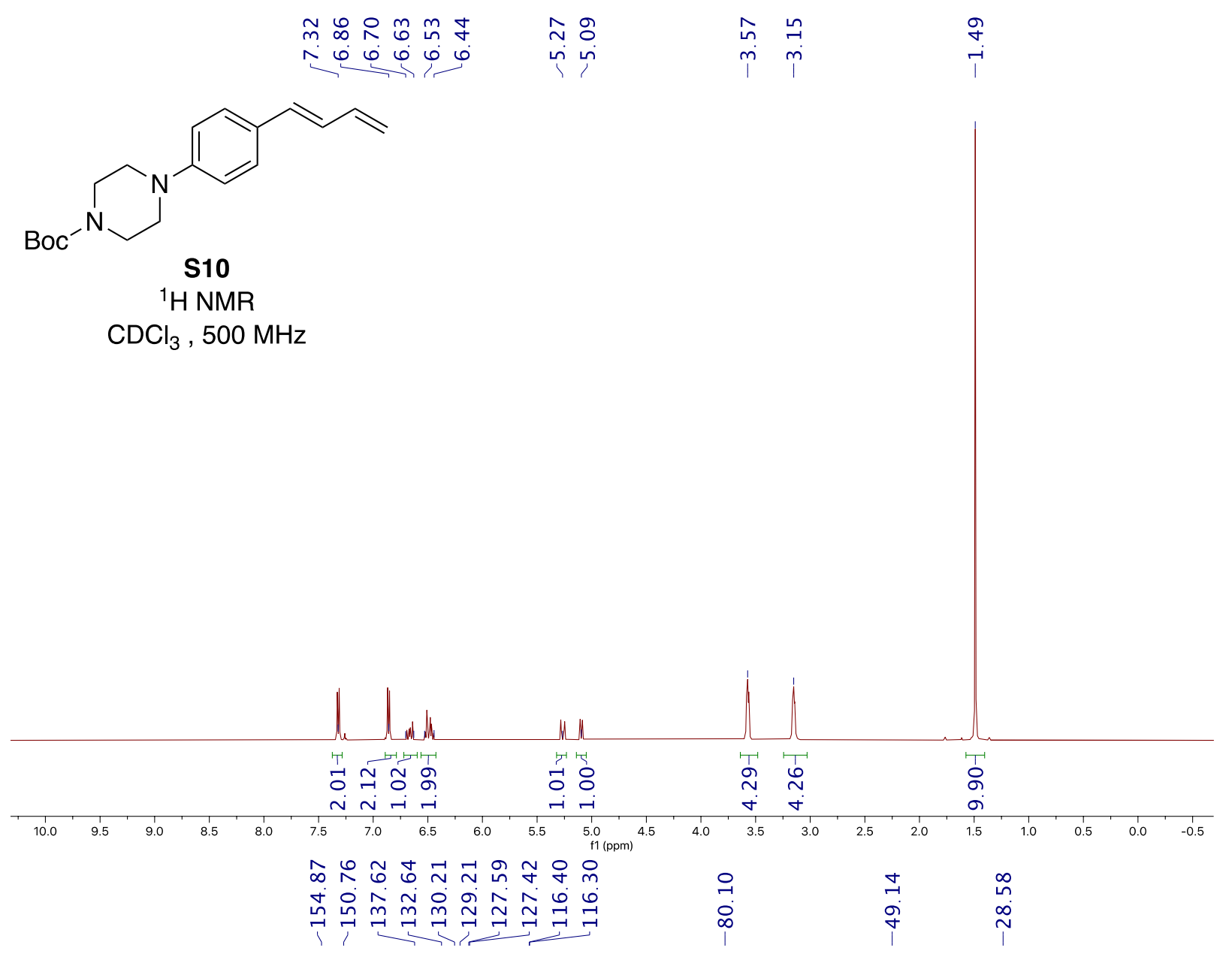<smiles>C=CC=Cc1ccc(N2CCN(C(=O)OC(C)(C)C)CC2)cc1</smiles>

S10

${ }^{13} \mathrm{C}$ NMR

$\mathrm{CDCl}_{3}, 126 \mathrm{MHz}$

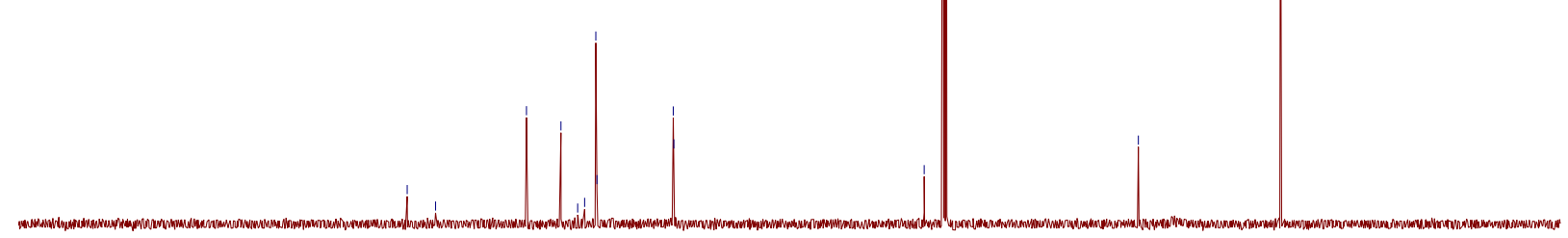

$\stackrel{7}{200}$

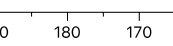

100 
Supporting Information

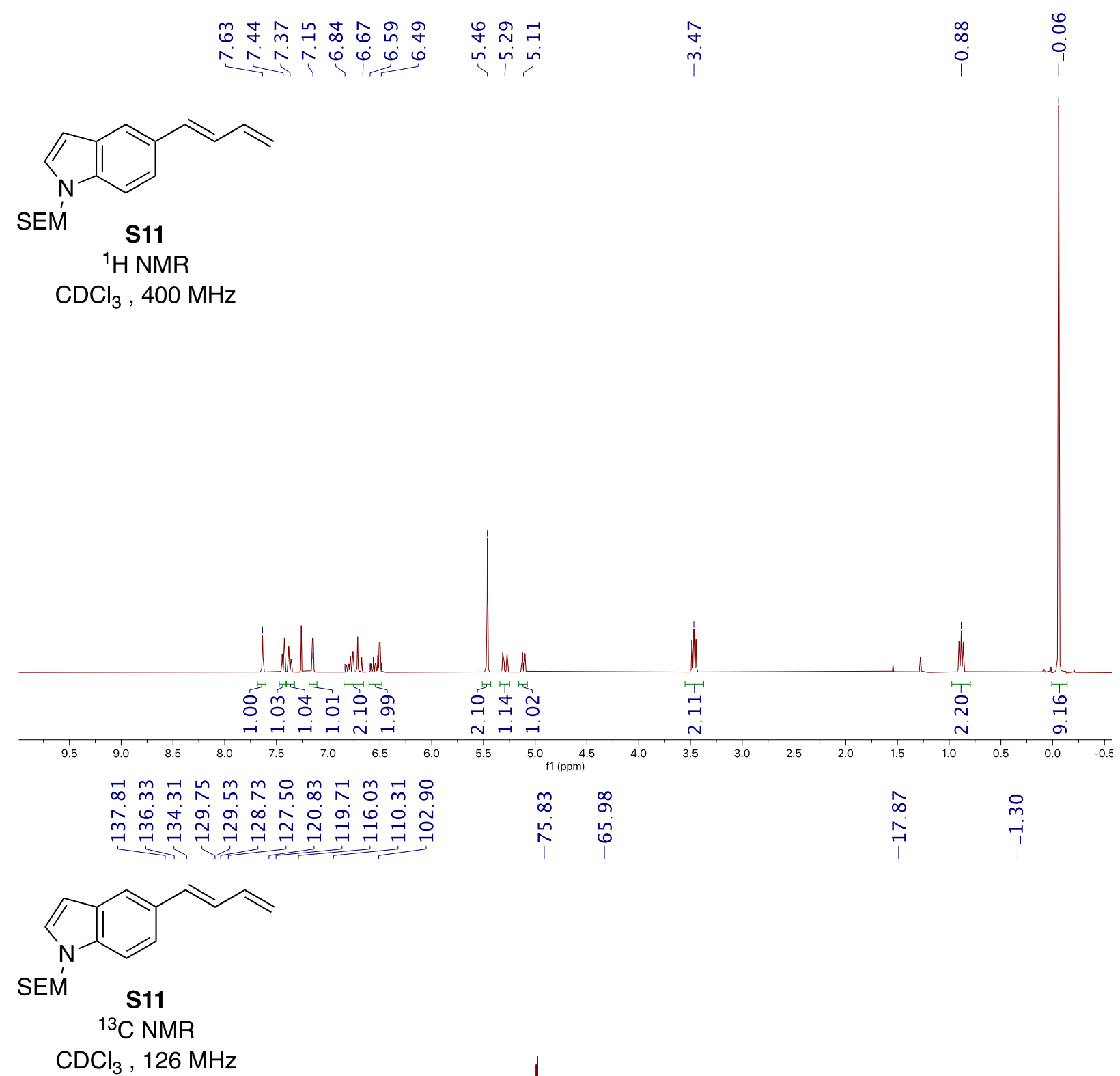

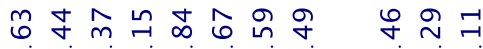

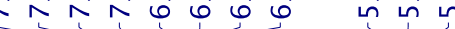

f 
Supporting Information
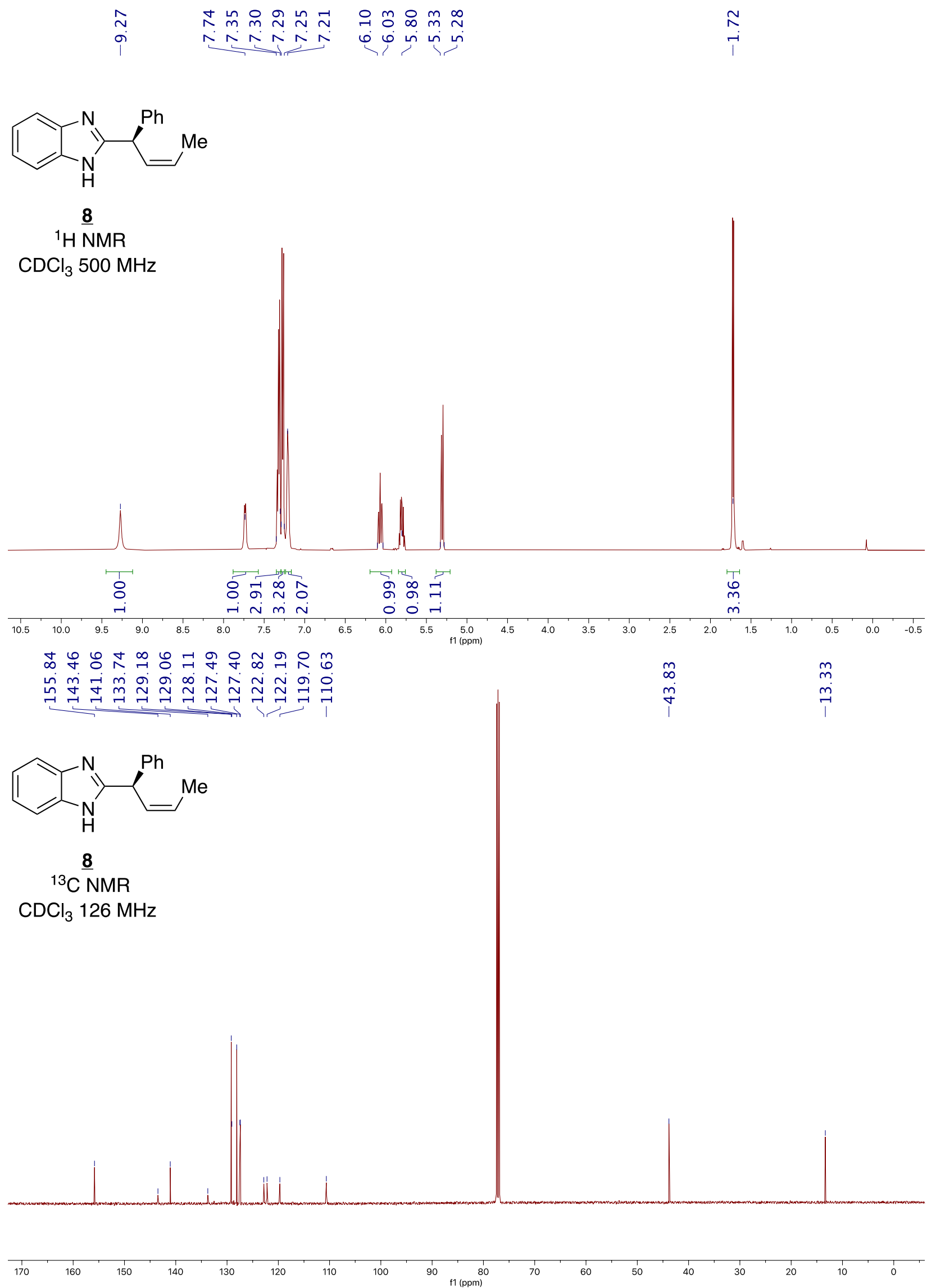
Supporting Information

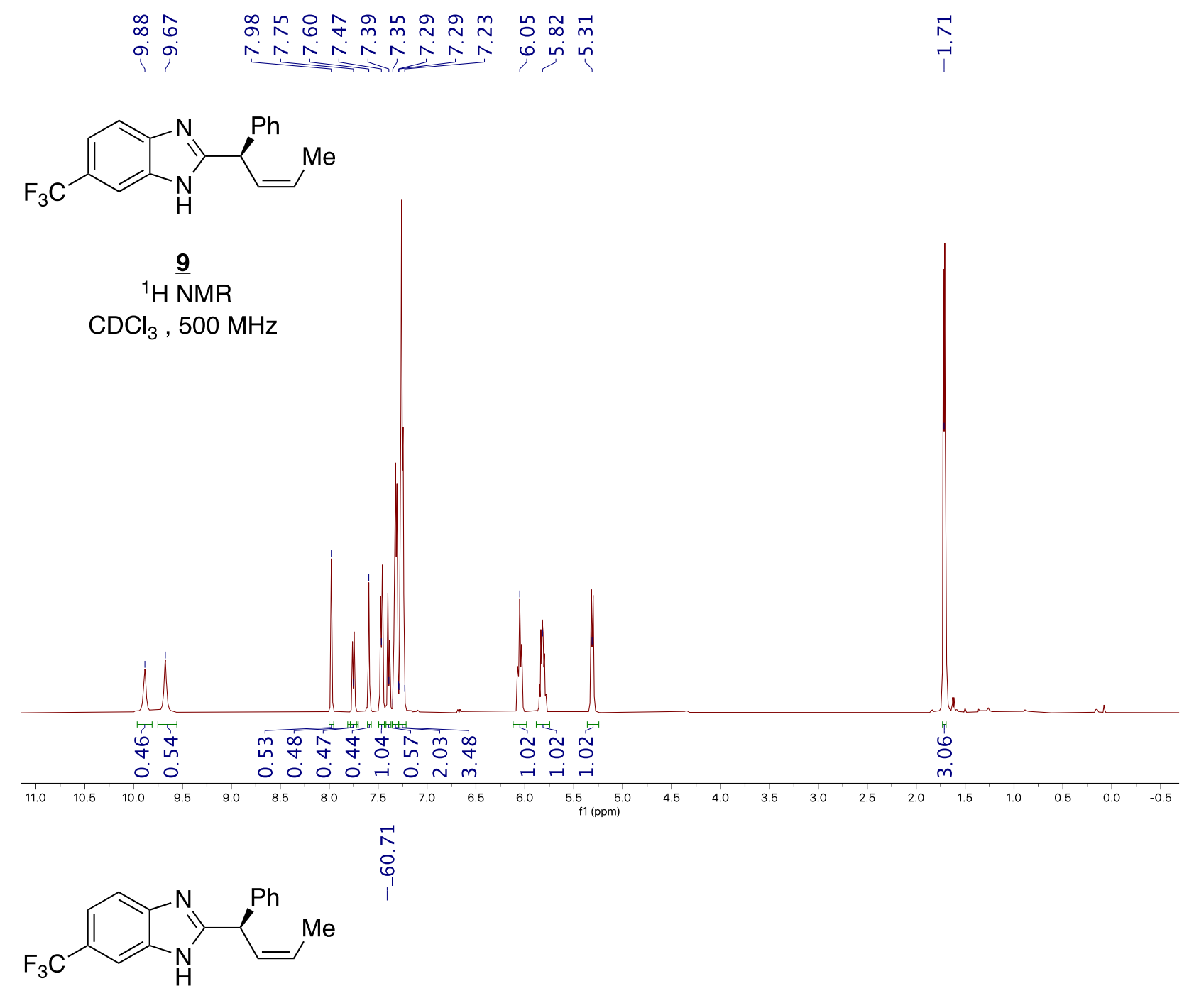

$\underline{9}$

${ }^{19} \mathrm{~F}$ NMR

$\mathrm{CDCl}_{3}, 471 \mathrm{MHz}$

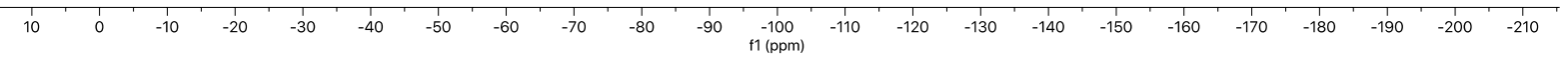




\section{Supporting Information}

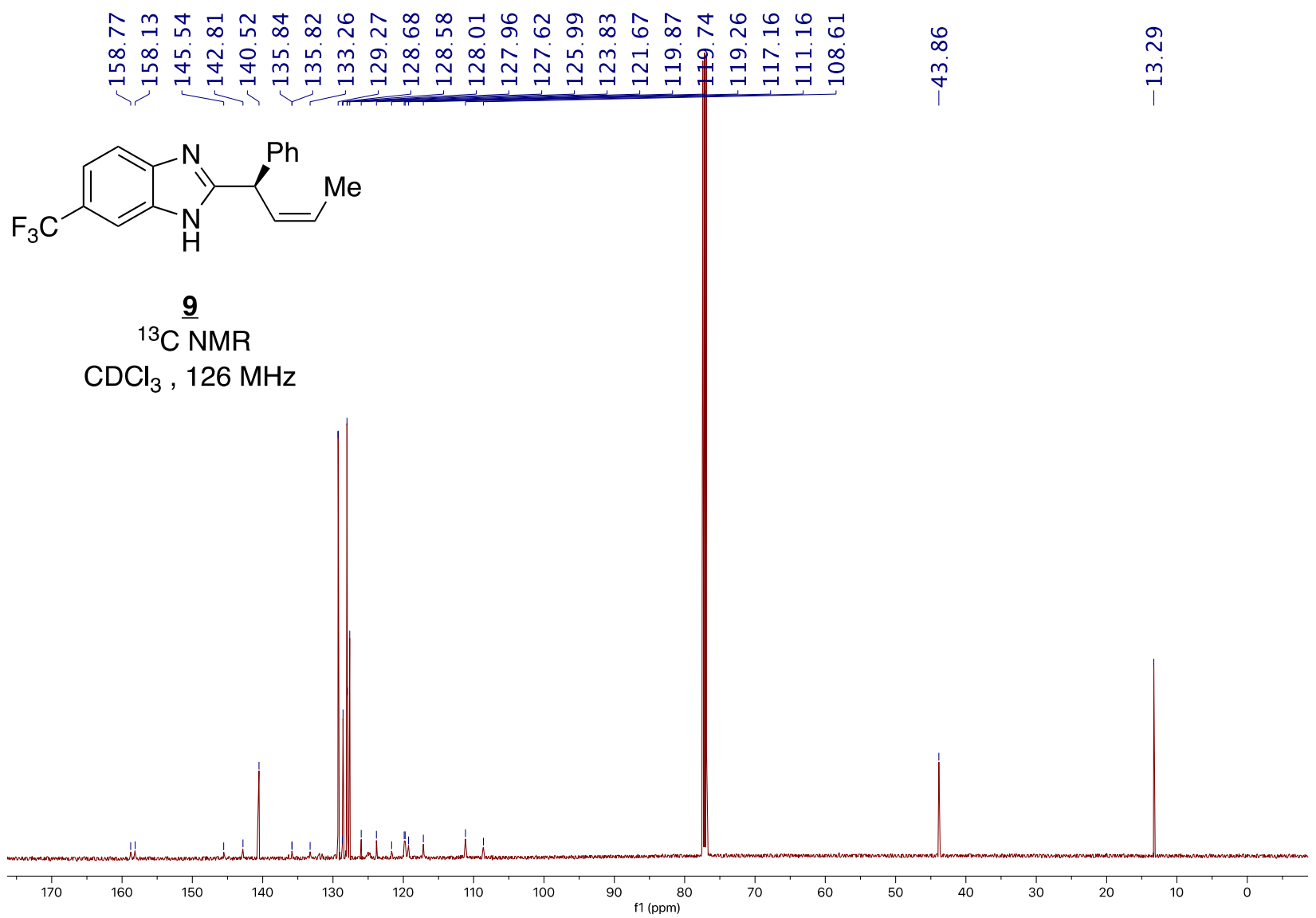


Supporting Information

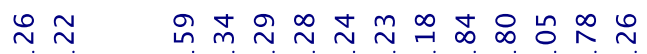

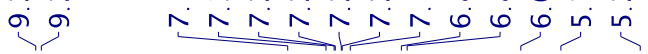

$\begin{array}{ll}9 & r \\ r & r\end{array}$<smiles>C/C=C\[C@@H](c1ccccc1)c1nc2ccc(OC)cc2[nH]1</smiles>

10

${ }^{1} \mathrm{H}$ NMR

$\mathrm{CDCl}_{3}, 500 \mathrm{MHz}$

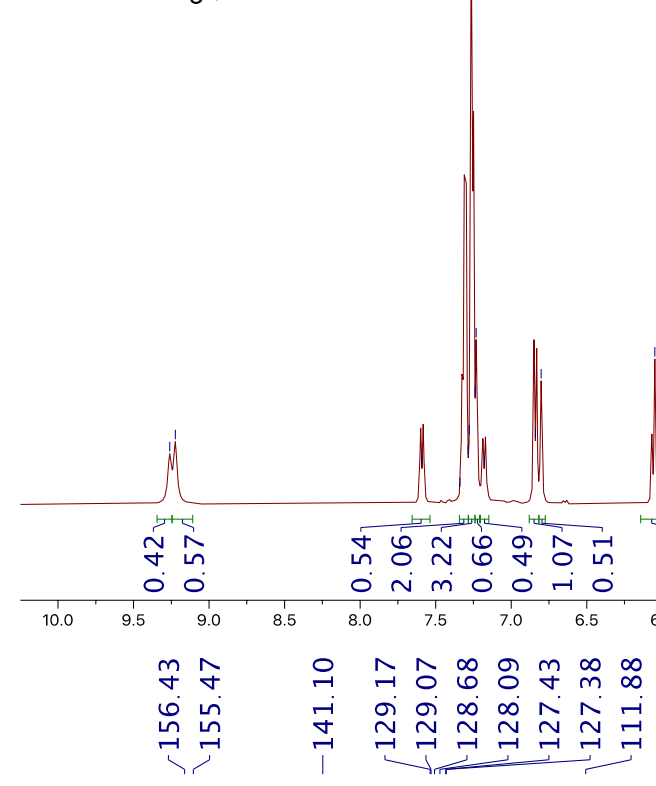

$\mathrm{MeO}_{\mathrm{Me}}^{\mathrm{Ph}}$

10

${ }^{13} \mathrm{C}$ NMR

$\mathrm{CDCl}_{3}, 126 \mathrm{MHz}$

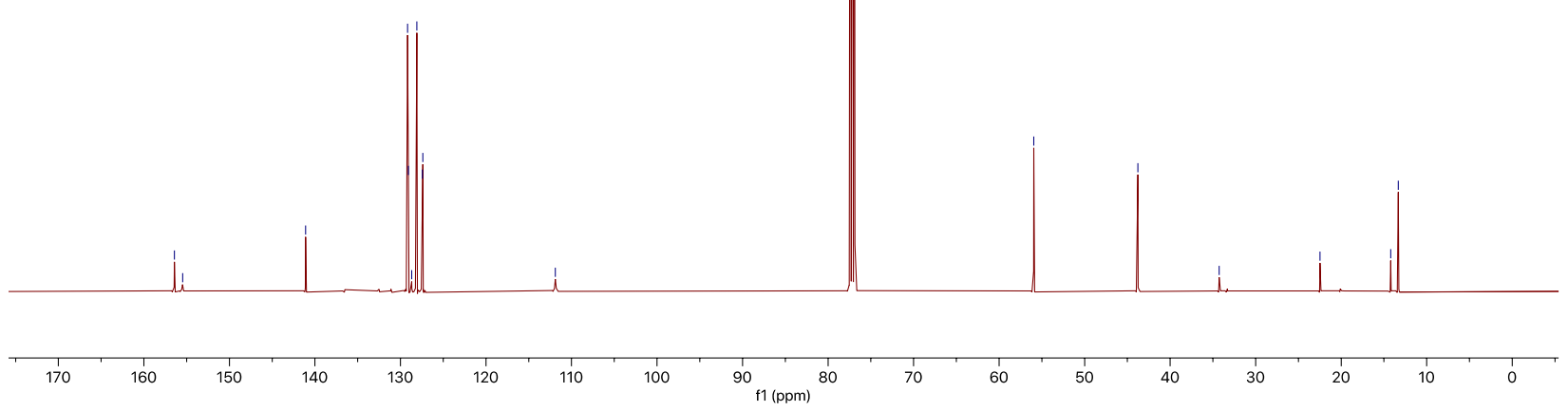


Supporting Information

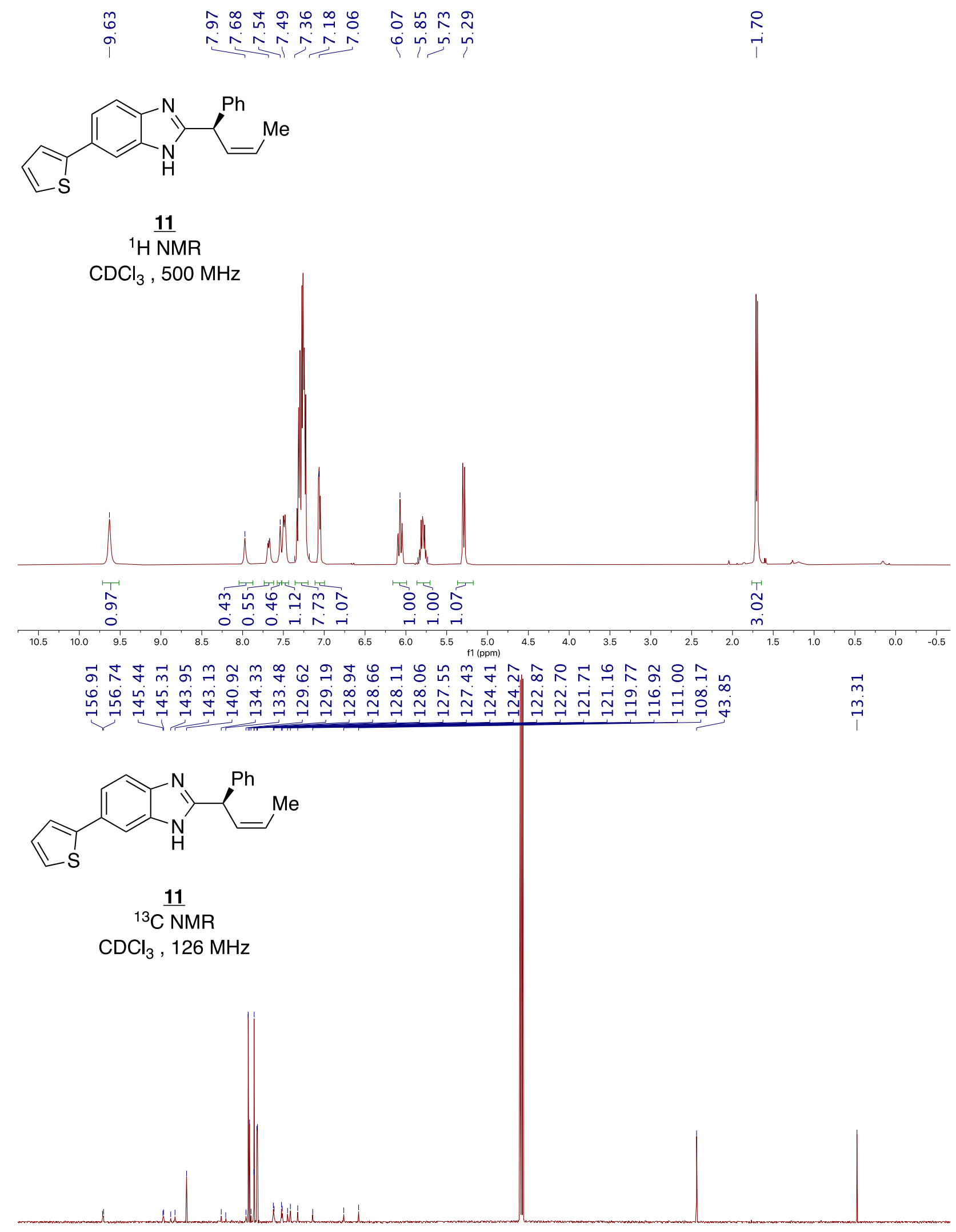

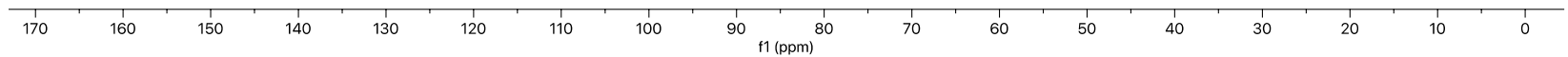




\section{Supporting Information}

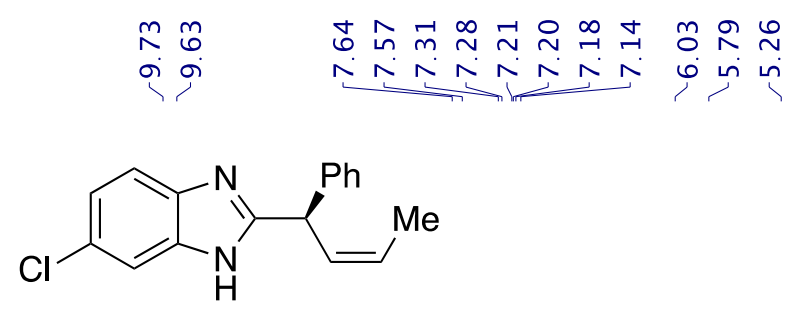

12

${ }^{1} \mathrm{H}$ NMR

$\mathrm{CDCl}_{3}, 500 \mathrm{MHz}$

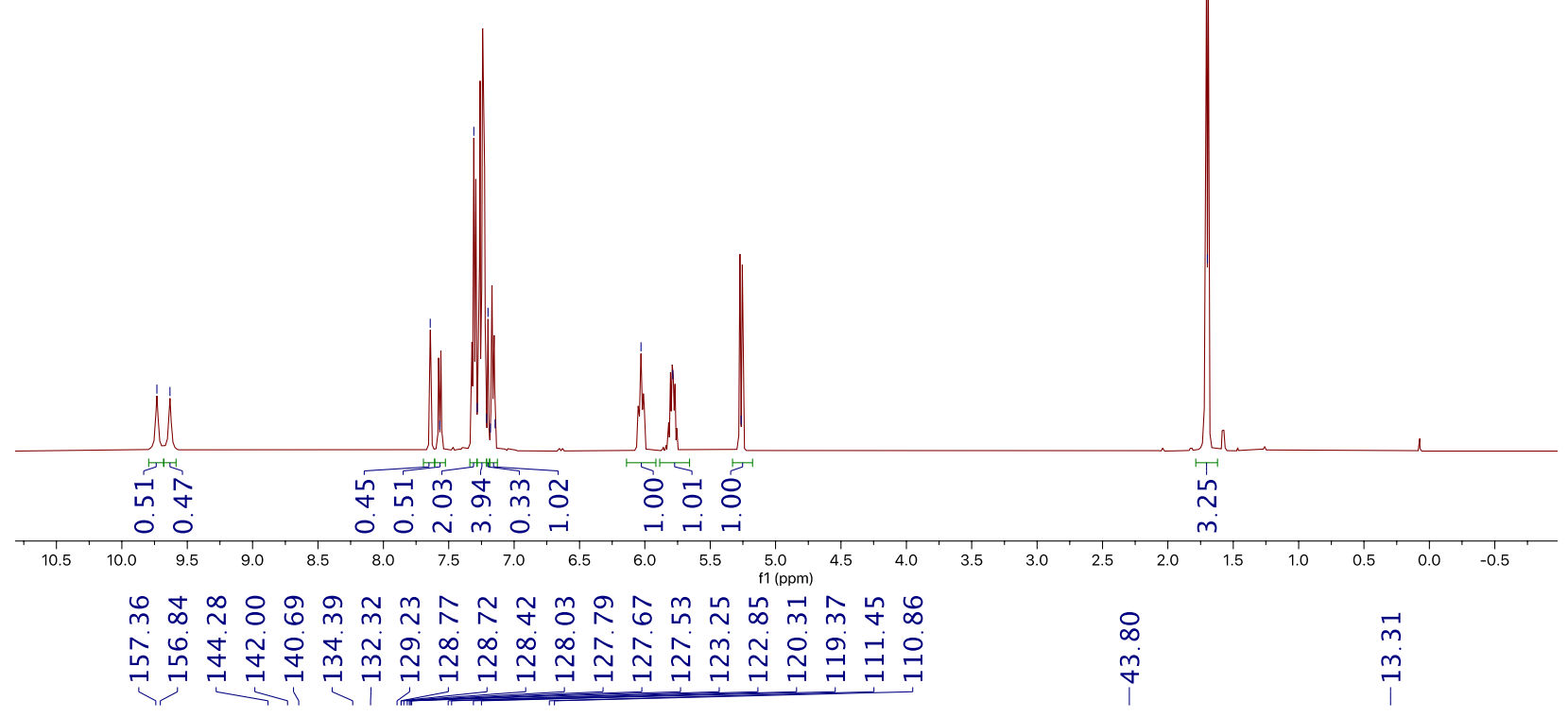<smiles>C/C=C\C(c1ccccc1)c1nc2ccc(Cl)cc2[nH]1</smiles>

12

${ }^{13} \mathrm{C}$ NMR

$\mathrm{CDCl}_{3}, 126 \mathrm{MHz}$

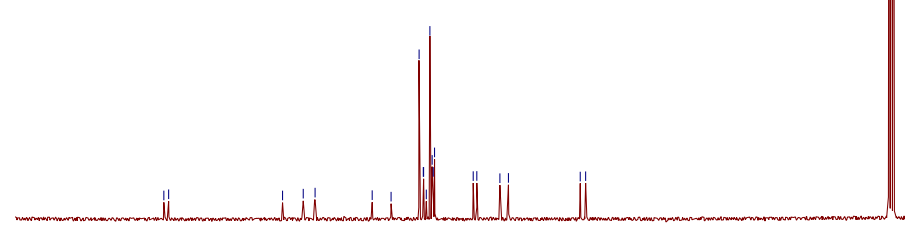

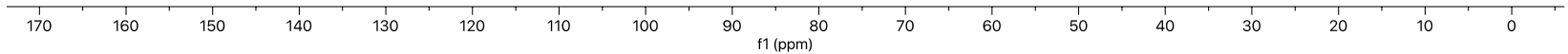


Supporting Information

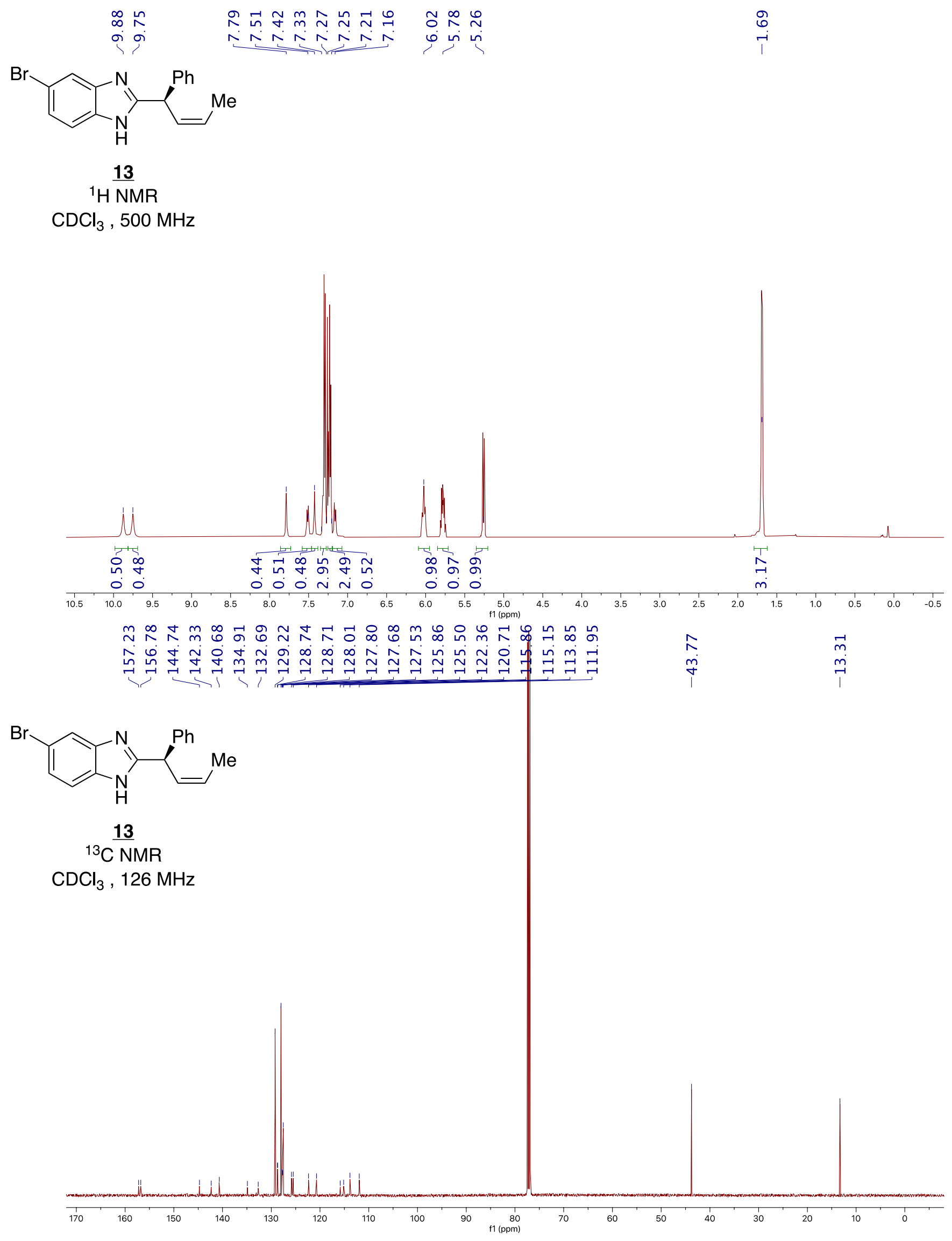


Supporting Information
$\underset{\substack{1 \\ \infty}}{\substack{1 \\ 0}}$

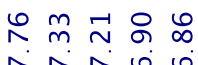
ப용
i in in in
$\stackrel{a}{i}$
$\stackrel{\text { ก }}{\stackrel{1}{i}}$

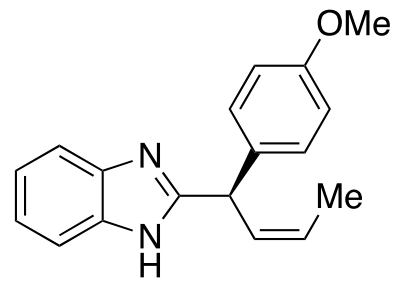

14

${ }^{1} \mathrm{H}$ NMR

$\mathrm{CDCl}_{3}, 500 \mathrm{MHz}$

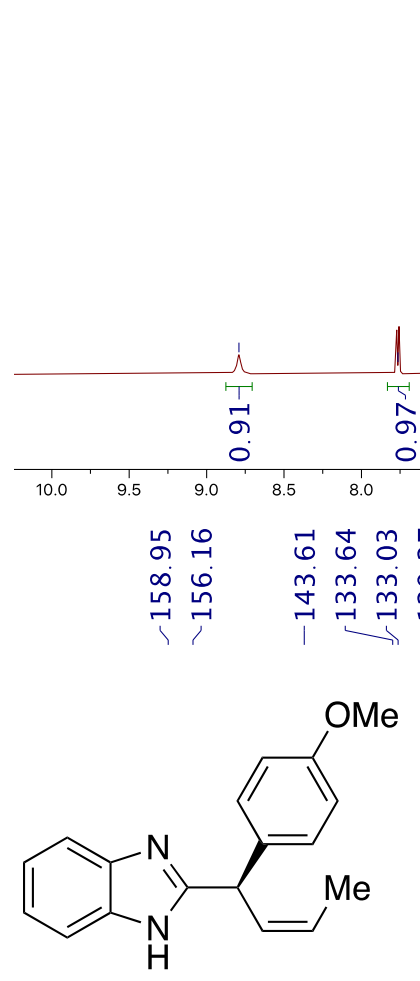

14

${ }^{13} \mathrm{C}$ NMR

$\mathrm{CDCl}_{3}, 126 \mathrm{MHz}$

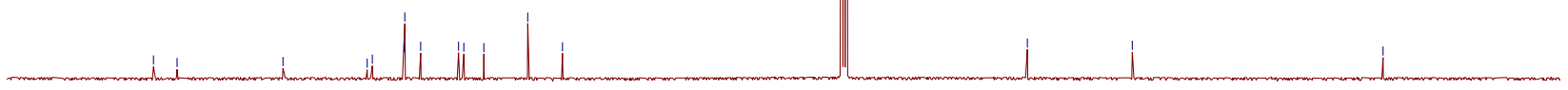

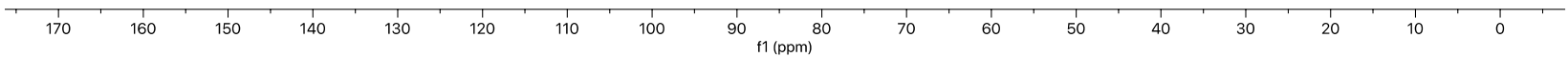


Supporting Information
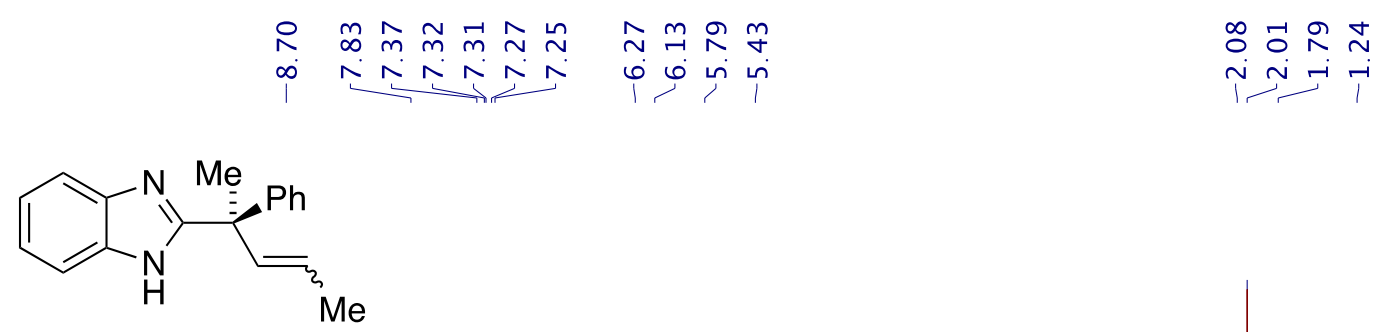

15

${ }^{1} \mathrm{H}$ NMR

$\mathrm{CDCl}_{3}, 500 \mathrm{MHz}$

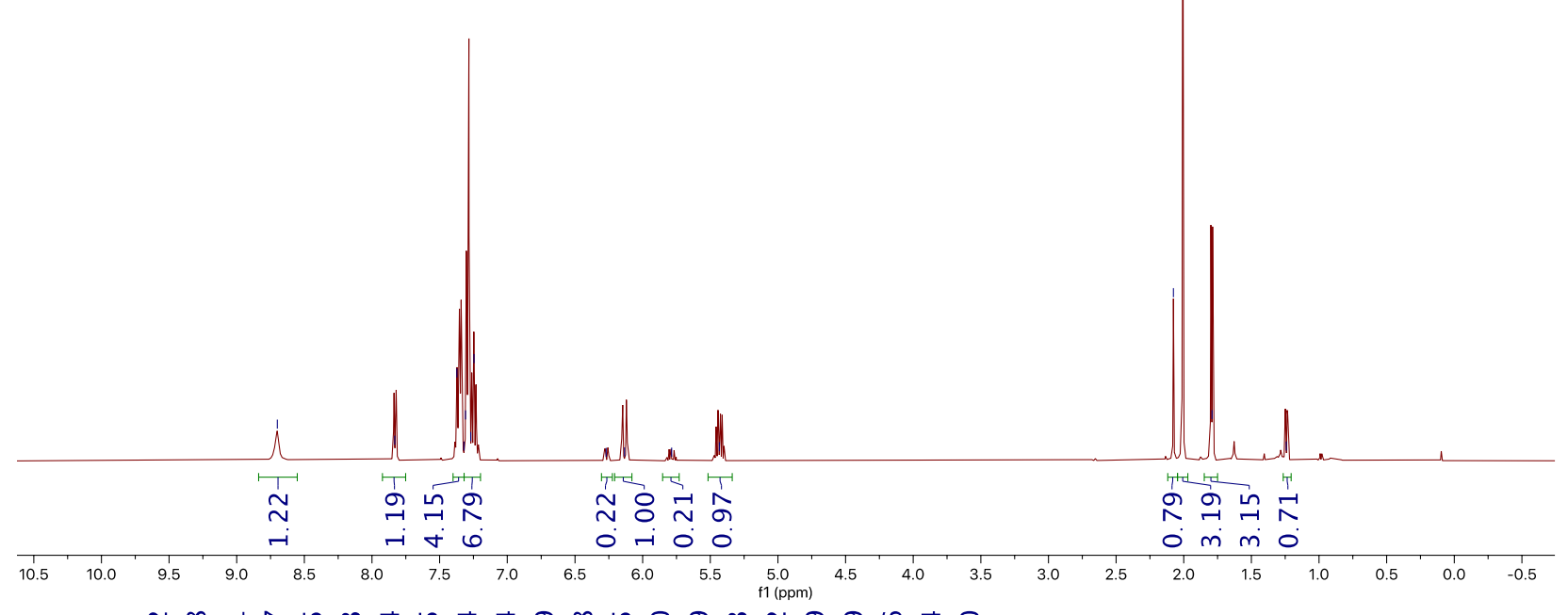

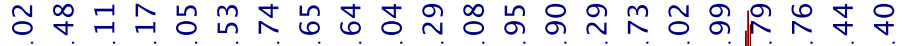

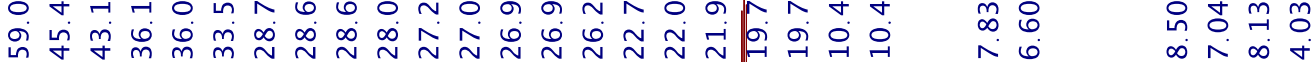

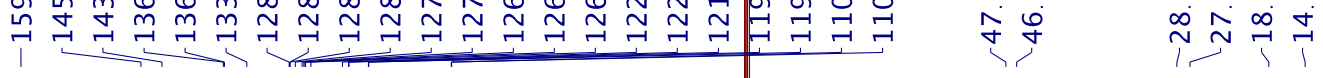

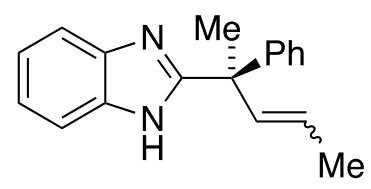

15

${ }^{13} \mathrm{C} \mathrm{NMR}$

$\mathrm{CDCl}_{3}, 126 \mathrm{MHz}$
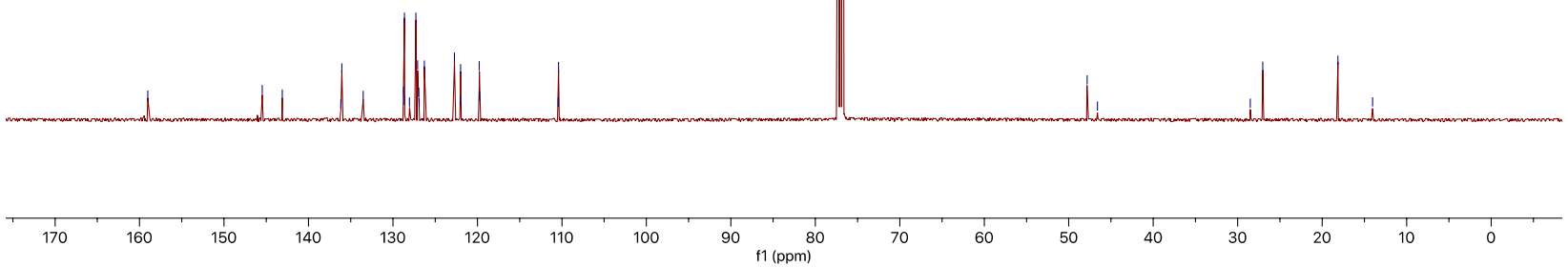
Supporting Information

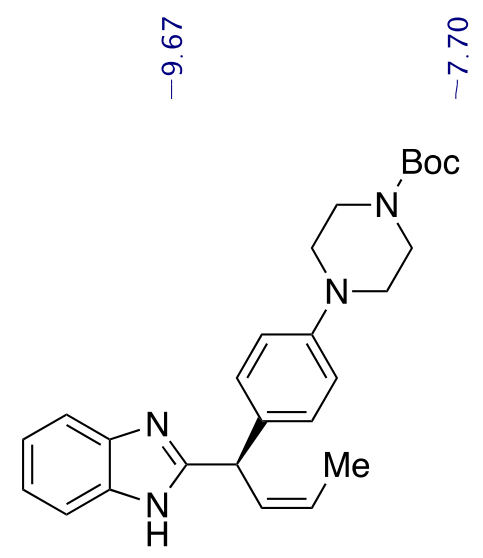

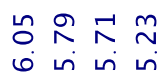

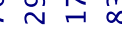

ம เ เก เ

$\begin{array}{ll}m & 0 \\ m & 0 \\ i & p\end{array}$

$\stackrel{i}{i} \stackrel{\substack{+i}}{i}$

16

${ }^{1} \mathrm{H}$ NMR

$\mathrm{CDCl}_{3}, 500 \mathrm{MHz}$

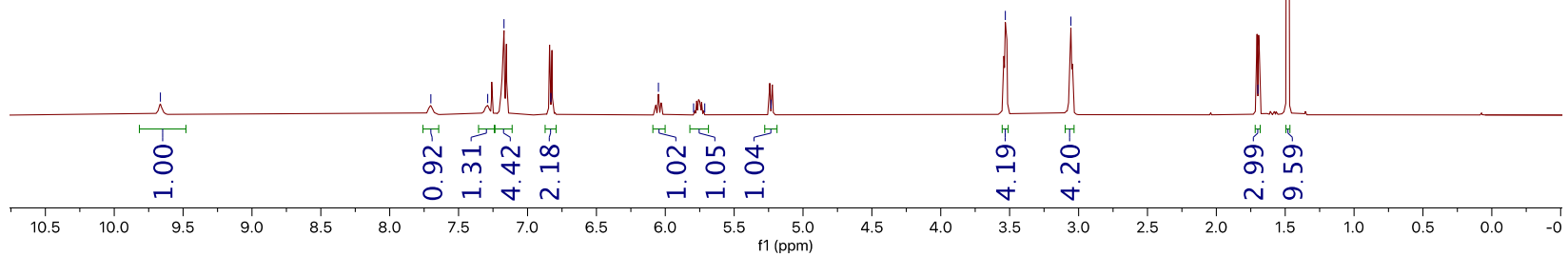

公

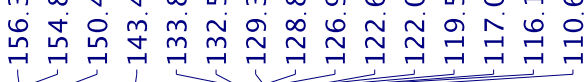

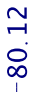

\begin{tabular}{ll}
$\infty$ & \multirow{2}{m}{} \\
$\stackrel{9}{\sigma}$ & $\stackrel{\sim}{\sim}$ \\
1 & 1
\end{tabular}

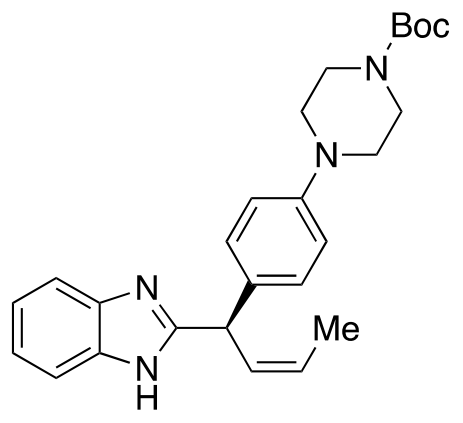

16

${ }^{13} \mathrm{C}$ NMR

$\mathrm{CDCl}_{3}, 126 \mathrm{MHz}$

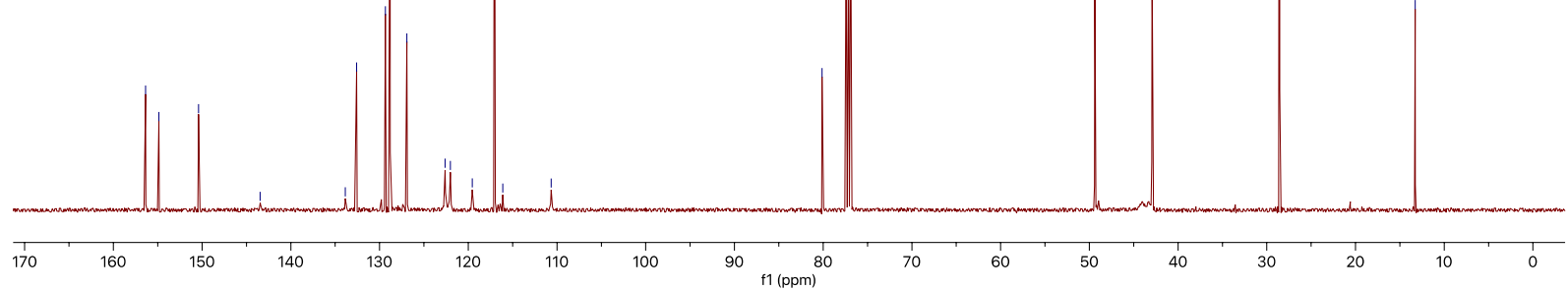


Supporting Information

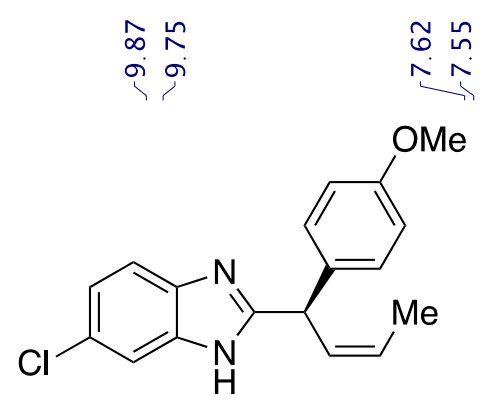

17

${ }^{1} \mathrm{H}$ NMR

$\mathrm{CDCl}_{3}, 500 \mathrm{MHz}$

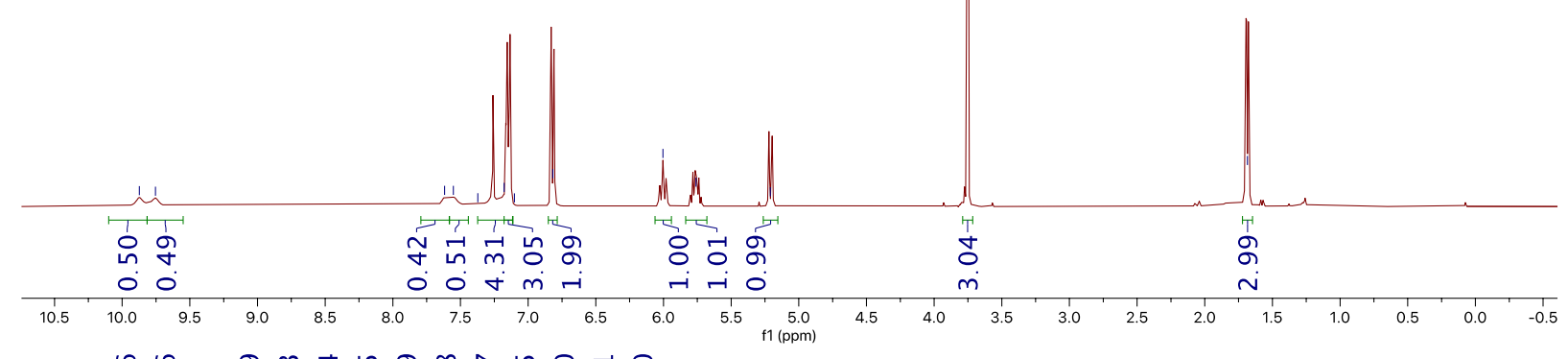

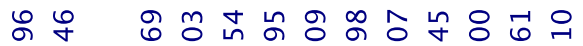

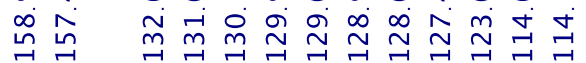

ᄀᄀ<smiles>C/C=C\[C@H](c1ccc(OC)cc1)c1nc2ccc(Cl)cc2[nH]1</smiles>

17

${ }^{13} \mathrm{C}$ NMR

$\mathrm{CDCl}_{3}, 126 \mathrm{MHz}$

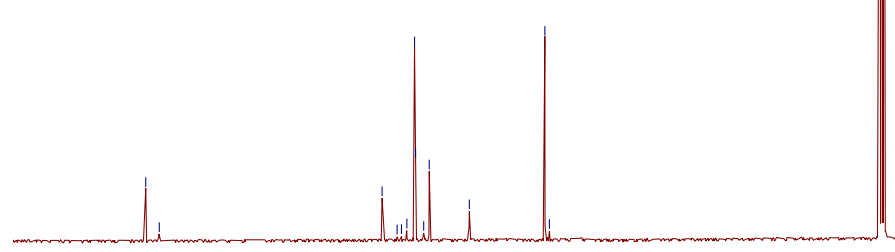

N

$\stackrel{m}{\uparrow}$

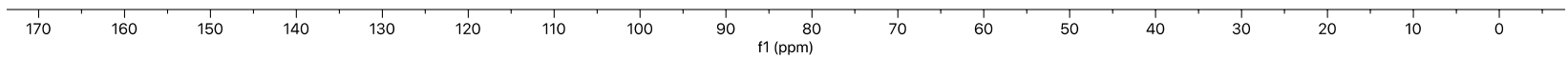


Supporting Information

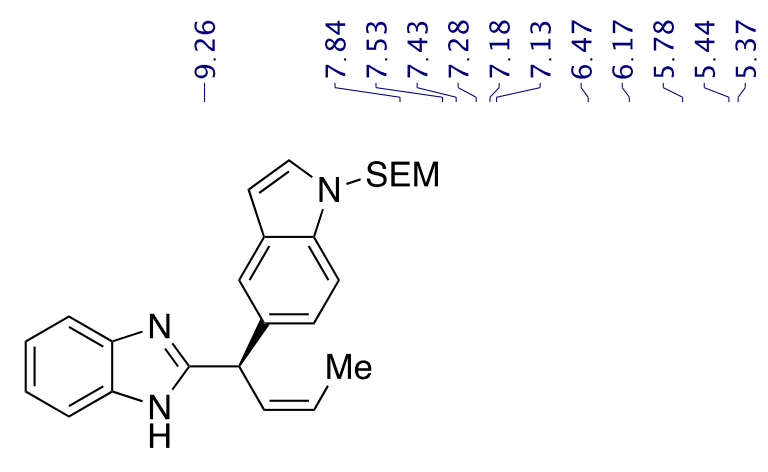

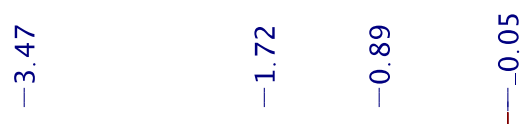

18

${ }^{1} \mathrm{H}$ NMR

$\mathrm{CDCl}_{3}, 500 \mathrm{MHz}$

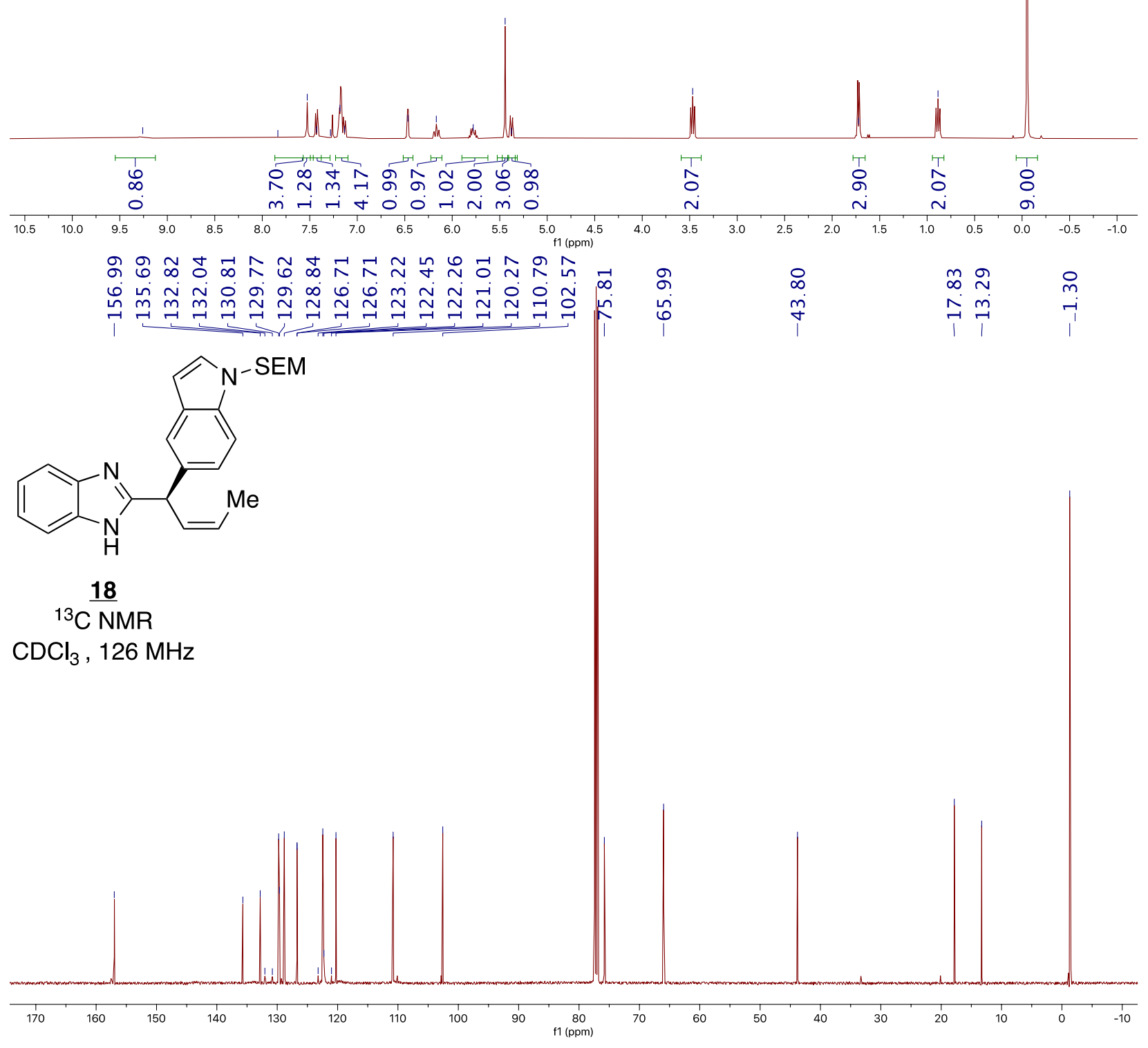


Supporting Information

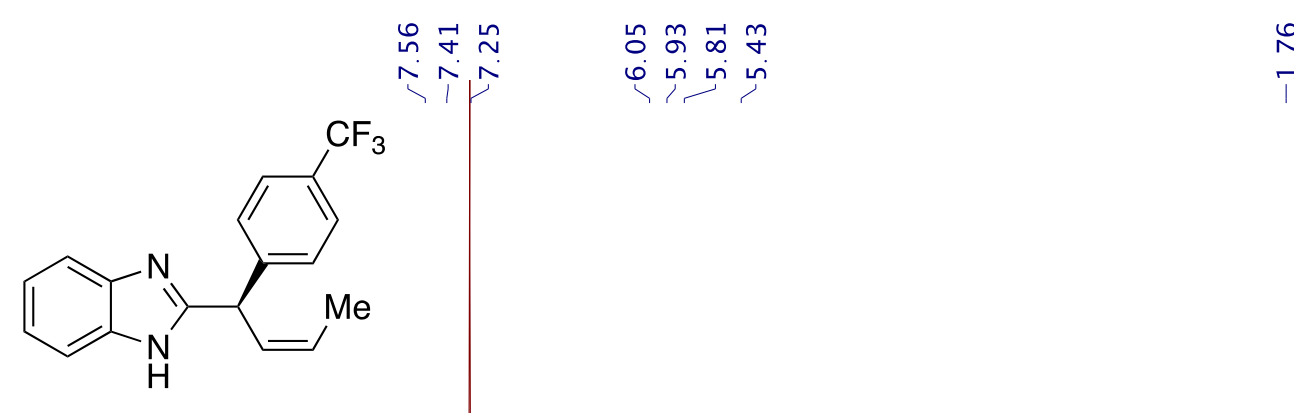

19

${ }^{1} \mathrm{H}$ NMR

$\mathrm{CDCl}_{3}, 400 \mathrm{MHz}$
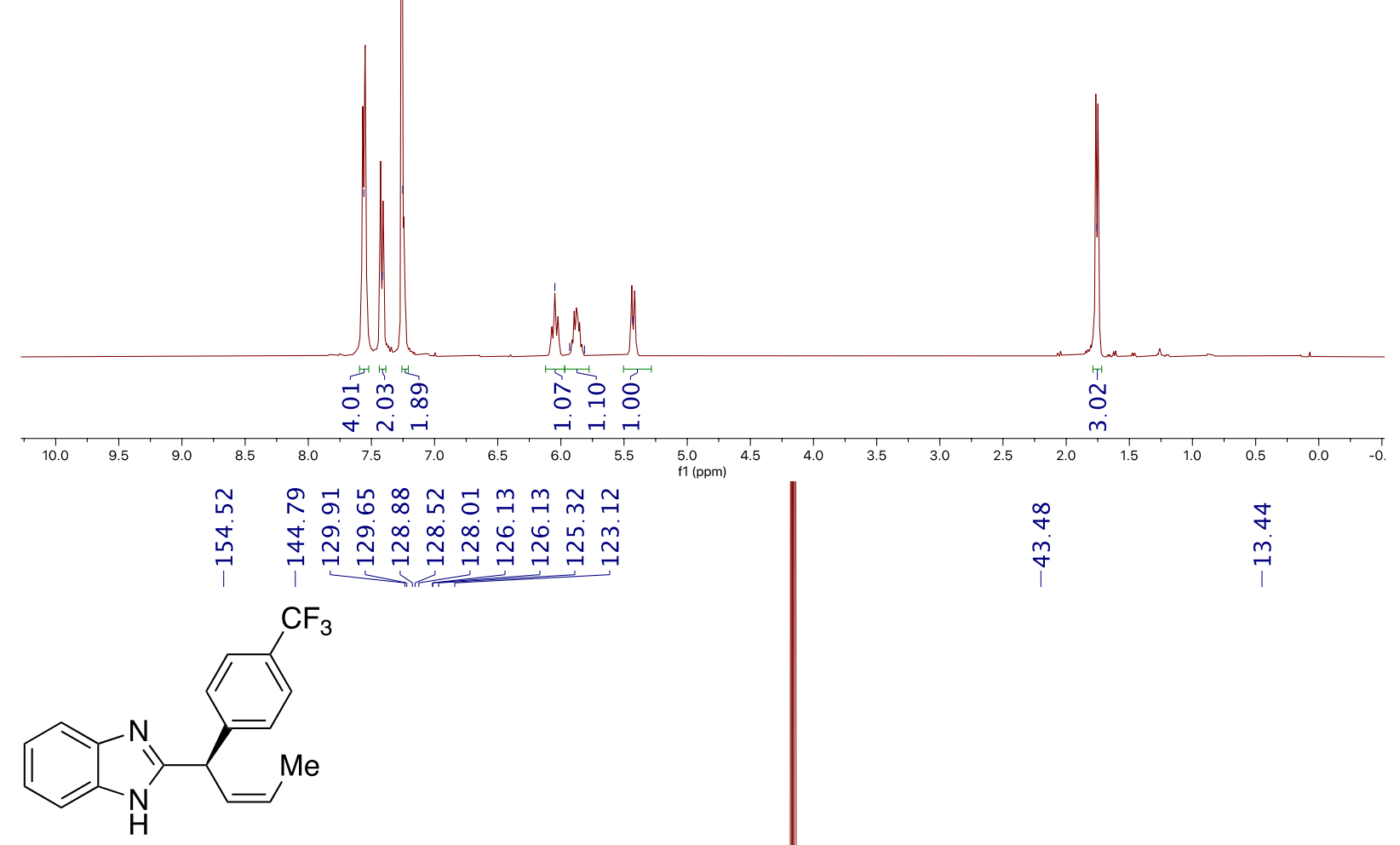

19

${ }^{13} \mathrm{C}$ NMR

$\mathrm{CDCl}_{3}, 126 \mathrm{MHz}$
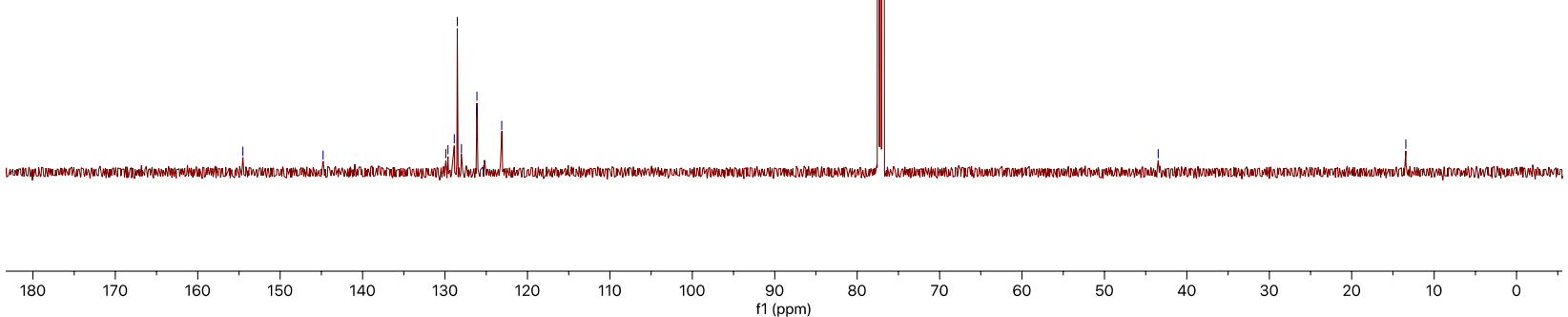
Supporting Information

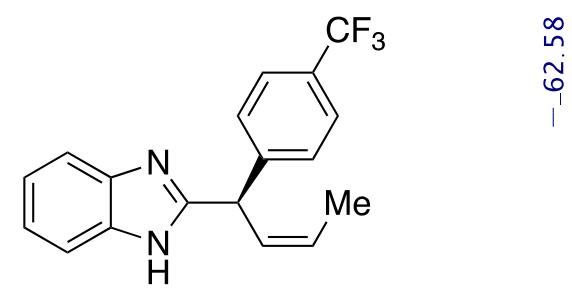

19

${ }^{19} \mathrm{~F}$ NMR

$\mathrm{CDCl}_{3}, 471 \mathrm{MHz}$

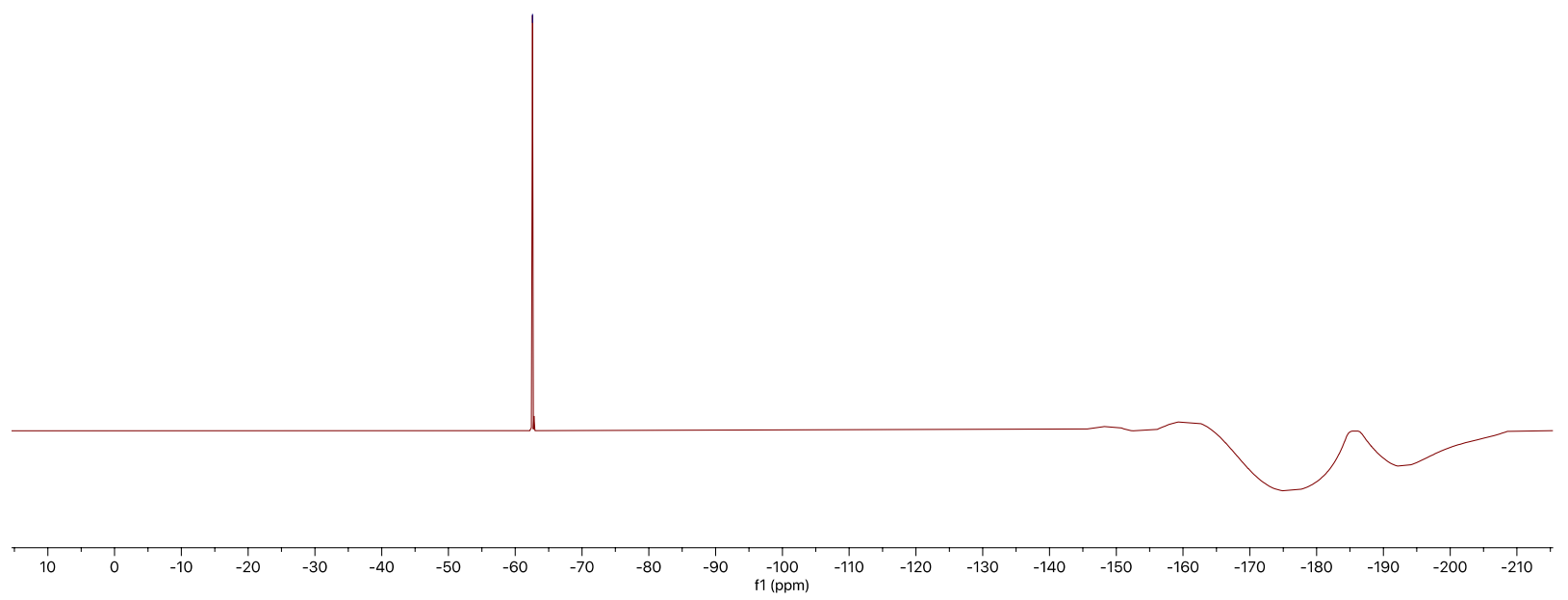


Supporting Information

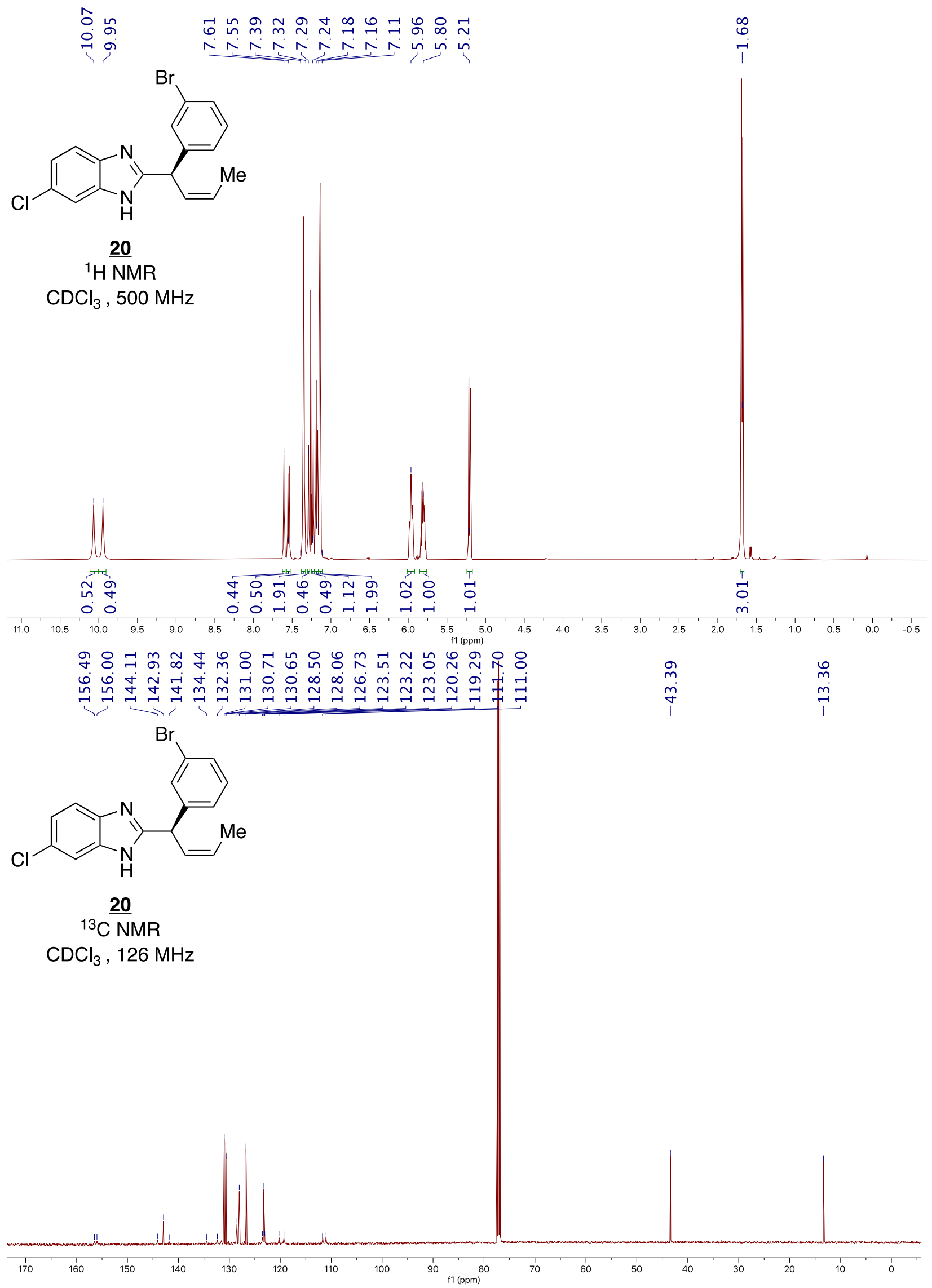


Supporting Information
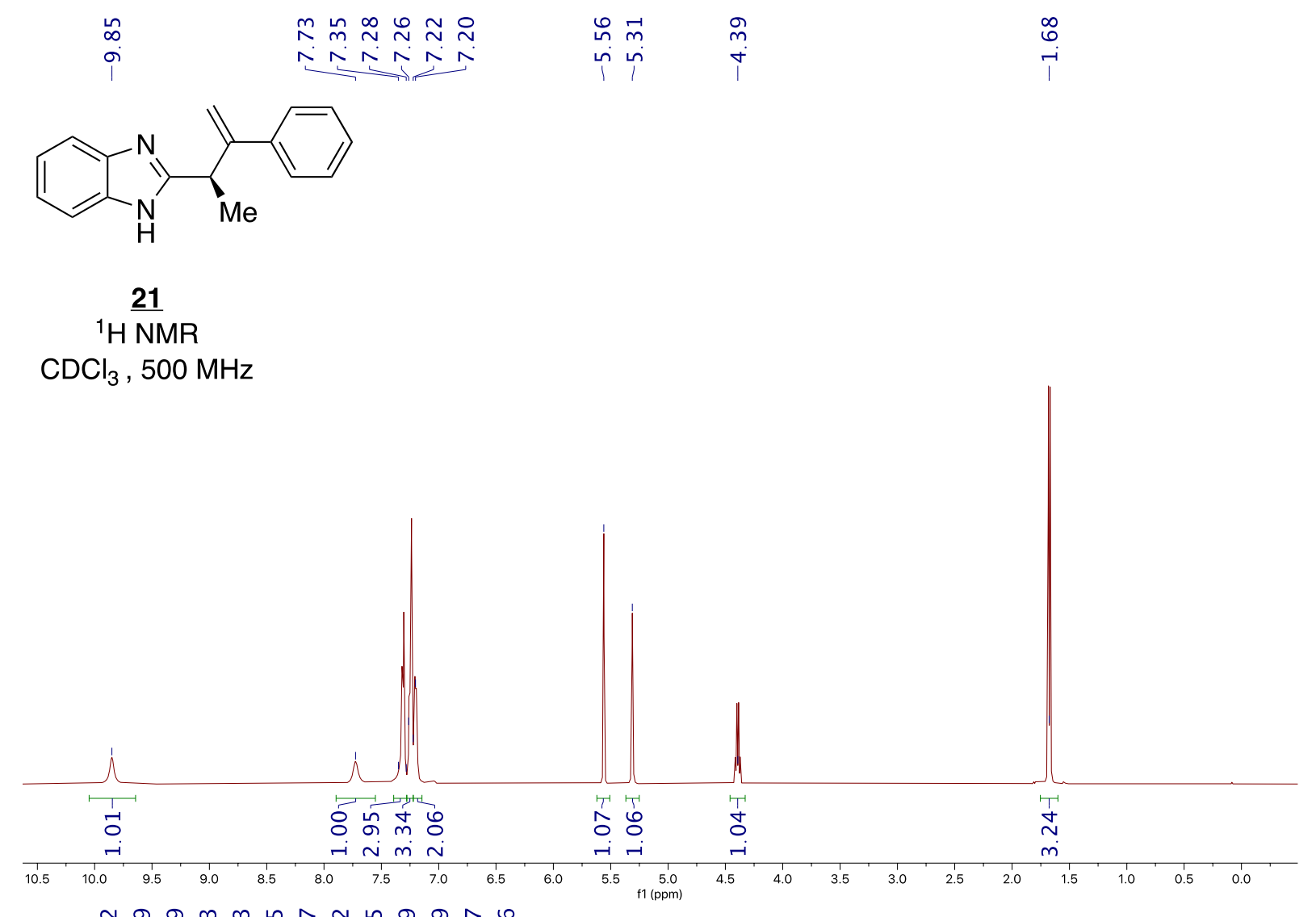

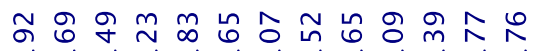

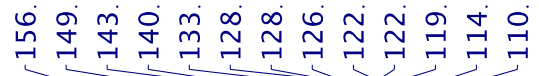

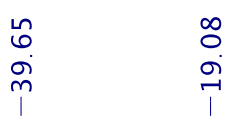

$\underset{\mathrm{H}}{\mathrm{N}}$

21

${ }^{13} \mathrm{C}$ NMR

$\mathrm{CDCl}_{3}, 126 \mathrm{MHz}$

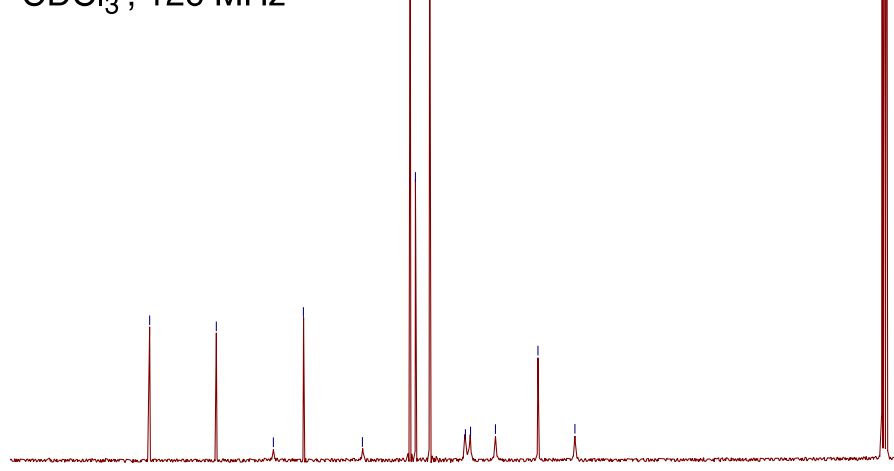

170

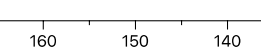

120

$90 \quad \begin{array}{r}1 \\ \mathrm{f} 1(\mathrm{ppm})\end{array}$ 
Supporting Information
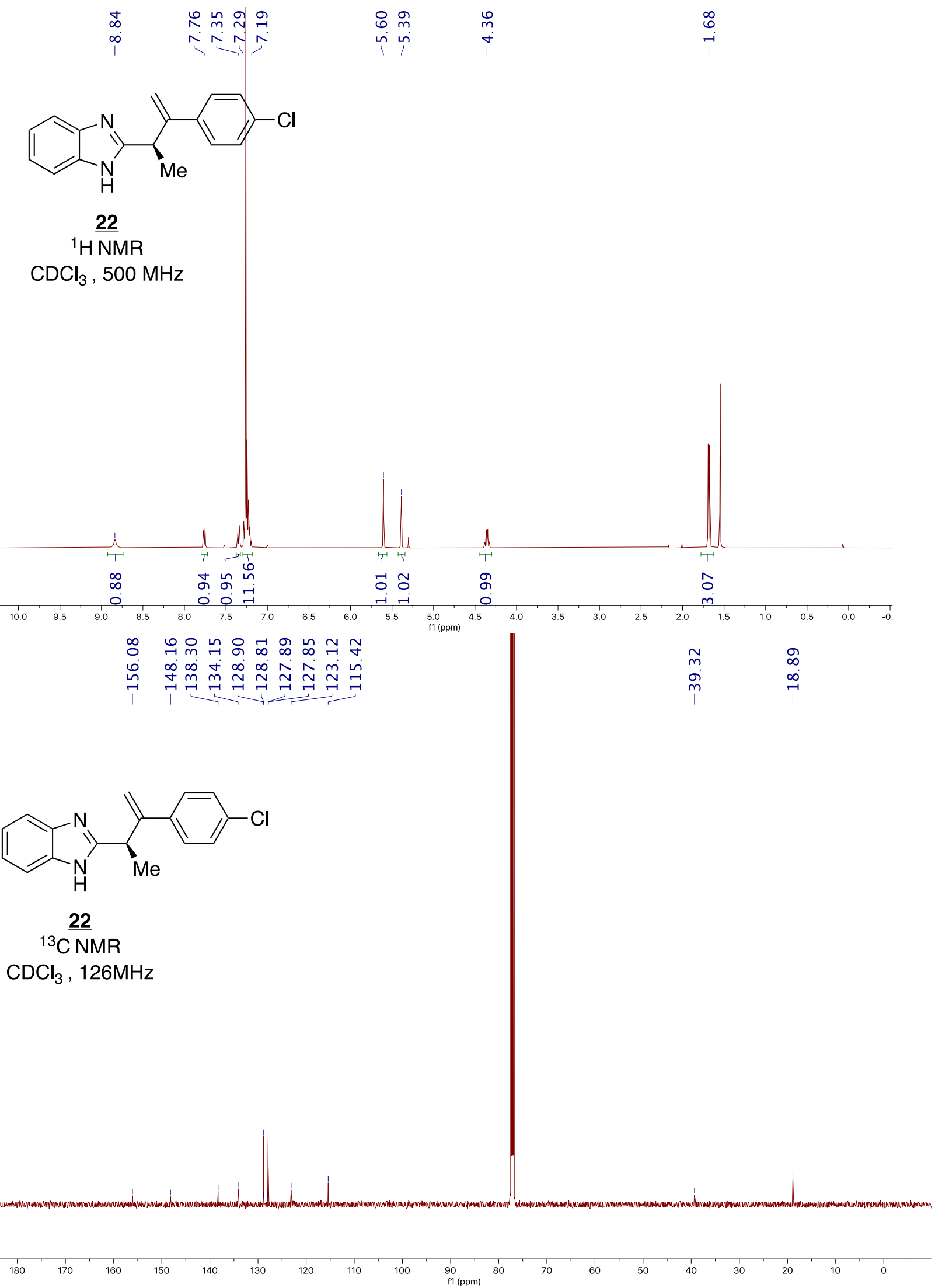
Supporting Information

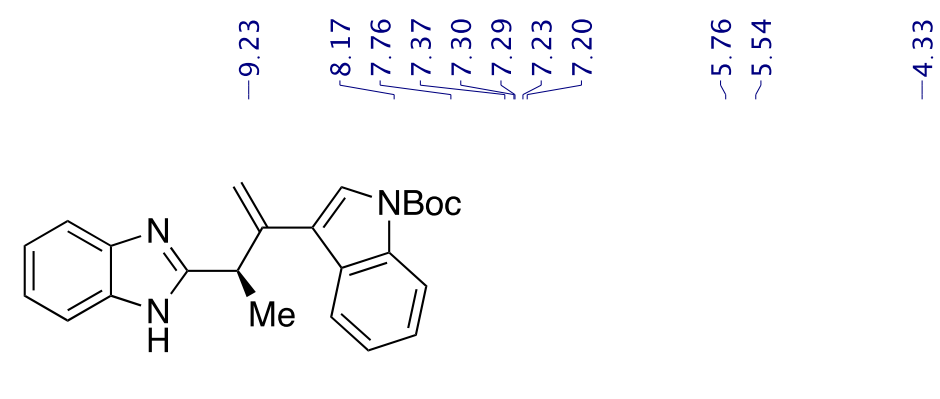

23

${ }^{1} \mathrm{H}$ NMR

$\mathrm{CDCl}_{3}, 500 \mathrm{MHz}$

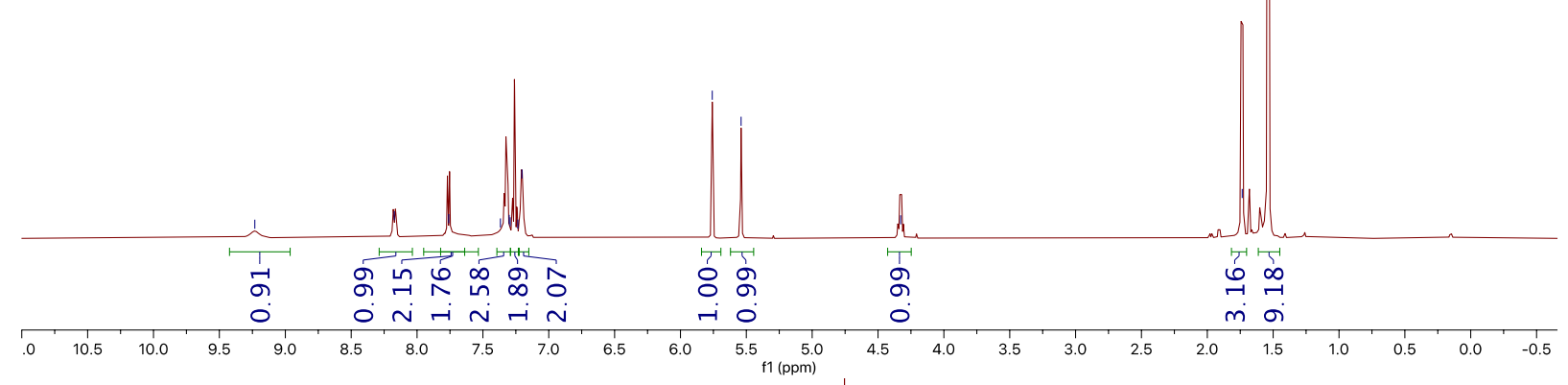

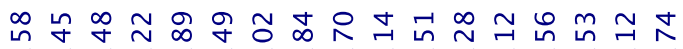

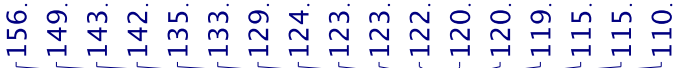<smiles>CC(C)C(=Cc1cn(C)c2ccccc12)C(C)c1nc2ccccc2[nH]1</smiles>

23

${ }^{13} \mathrm{C}$ NMR

$\mathrm{CDCl}_{3}, 126 \mathrm{MHz}$

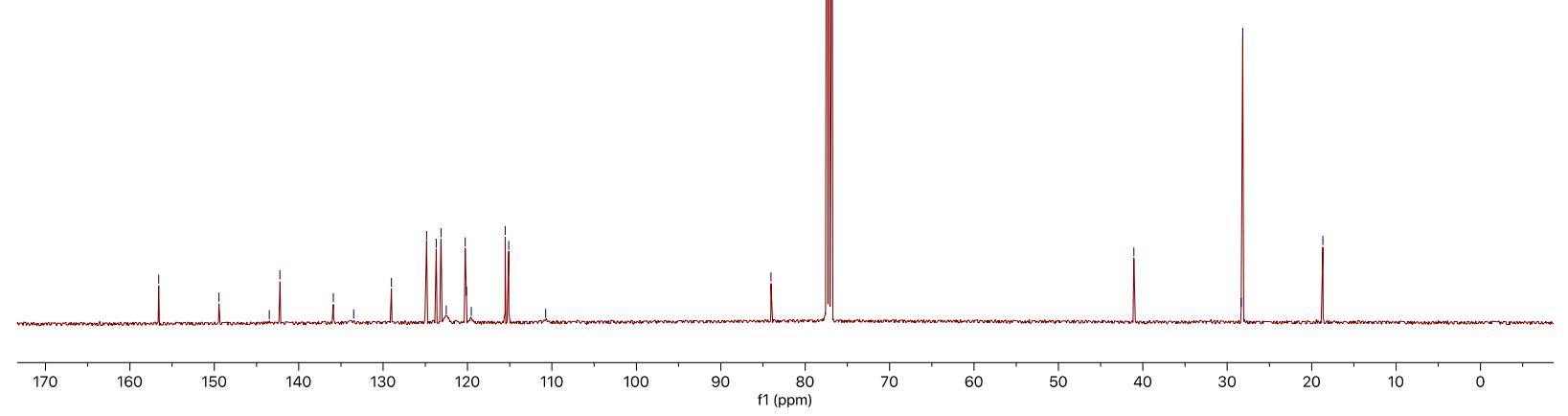




\section{Supporting Information}
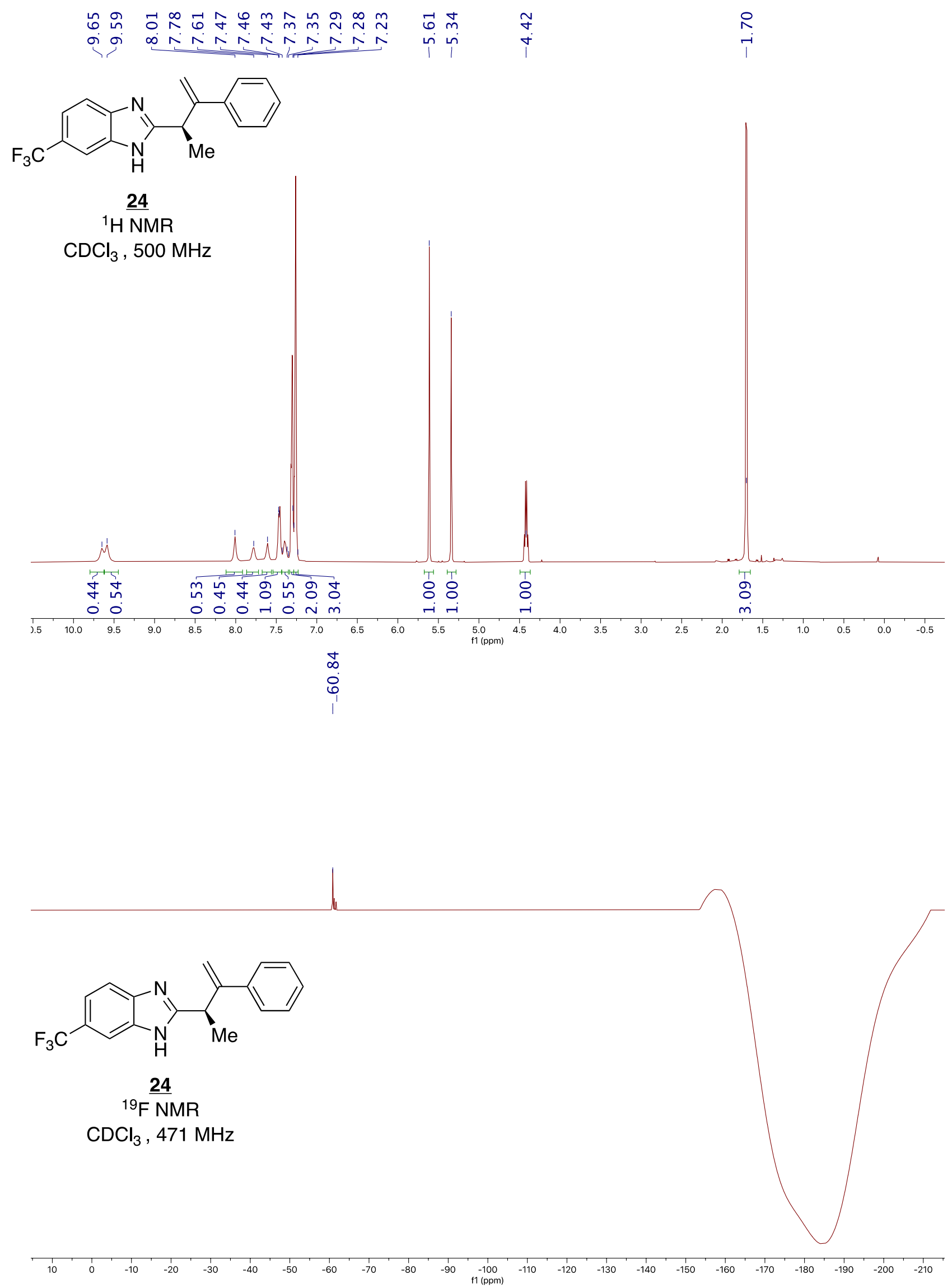


\section{Supporting Information}

เก

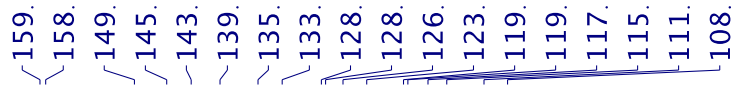

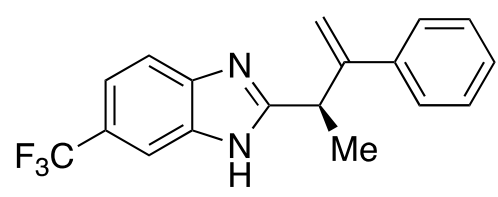

24

${ }^{13} \mathrm{C}$ NMR

$\mathrm{CDCl}_{3}, 126 \mathrm{MHz}$

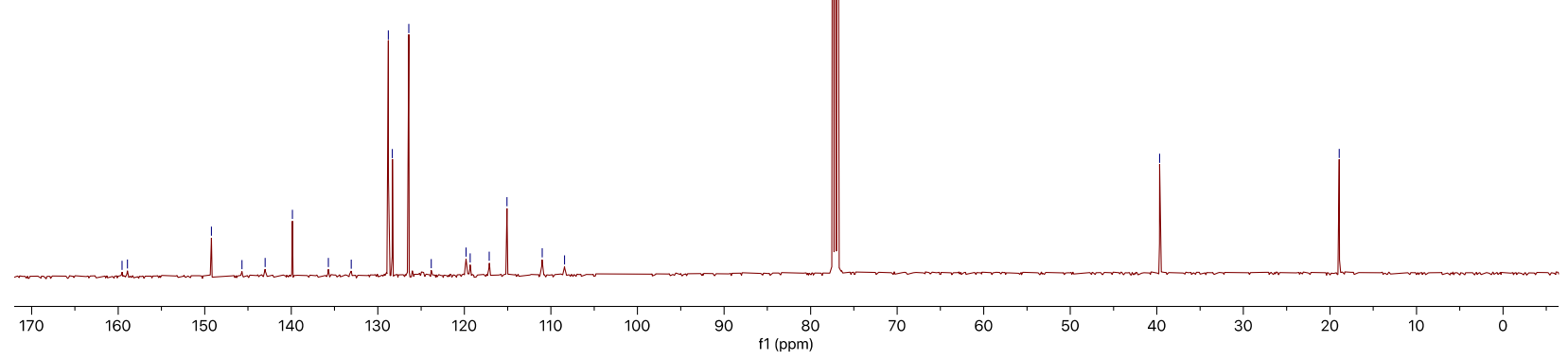


Supporting Information

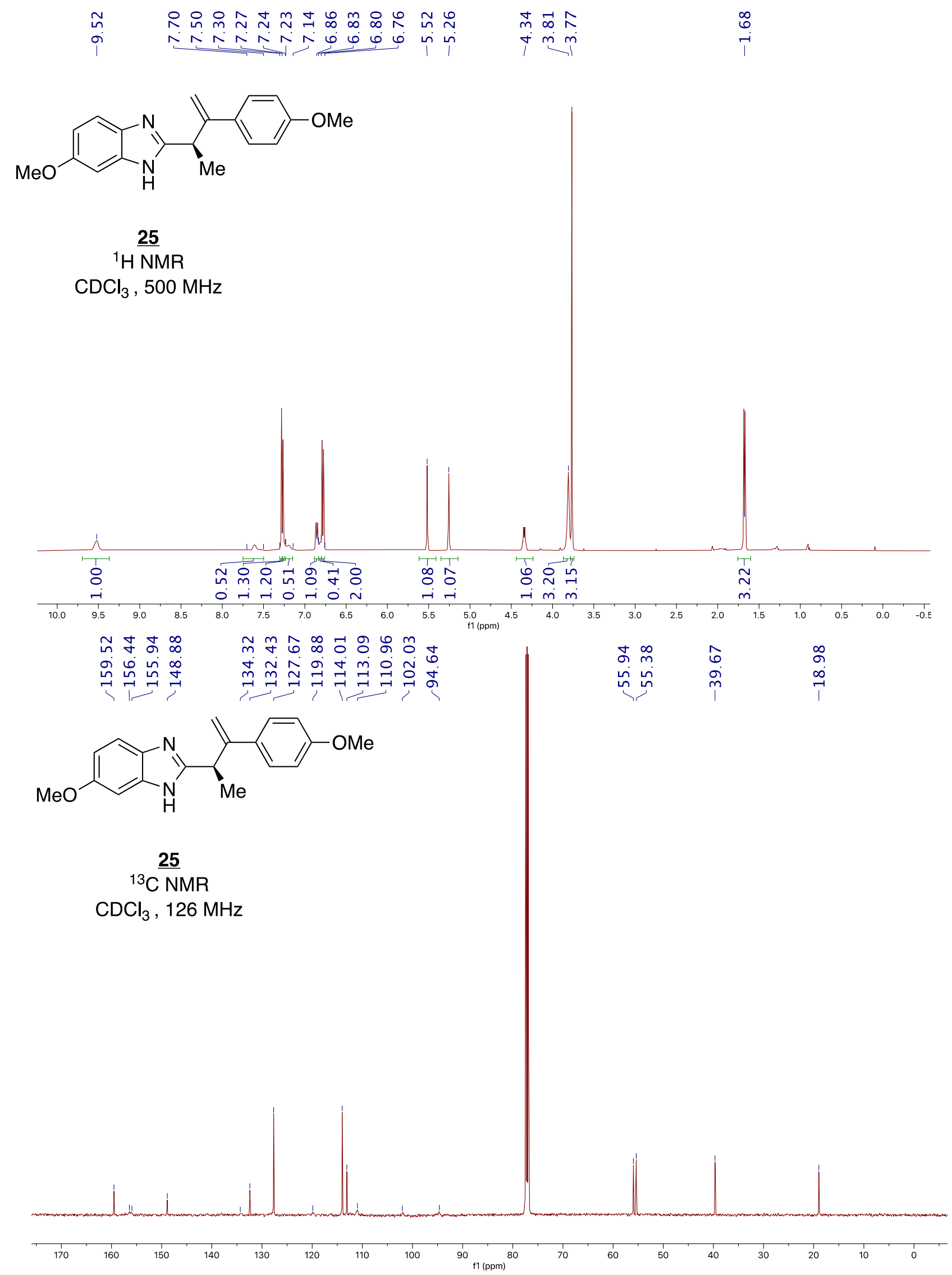




\subsection{Chiral SFC and HPLC Traces of Allylation Products}<smiles>C/C=C\[C@H](c1ccccc1)c1nc2ccccc2[nH]1</smiles>
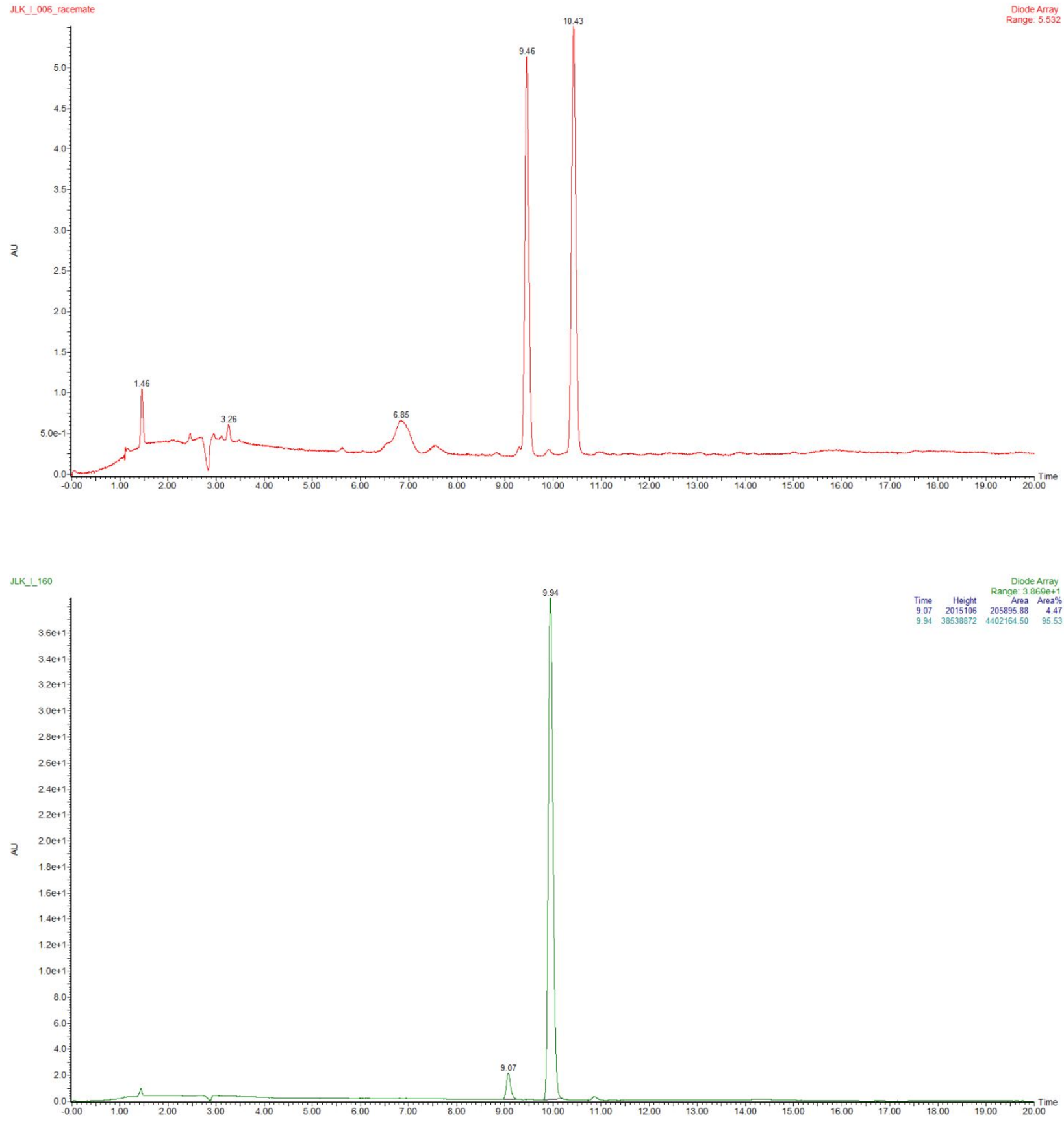


\section{Supporting Information}<smiles>C/C=C\C(c1ccccc1)c1nc2ccc(C(F)(F)F)cc2[nH]1</smiles>

9

JLK_I_110_RAC
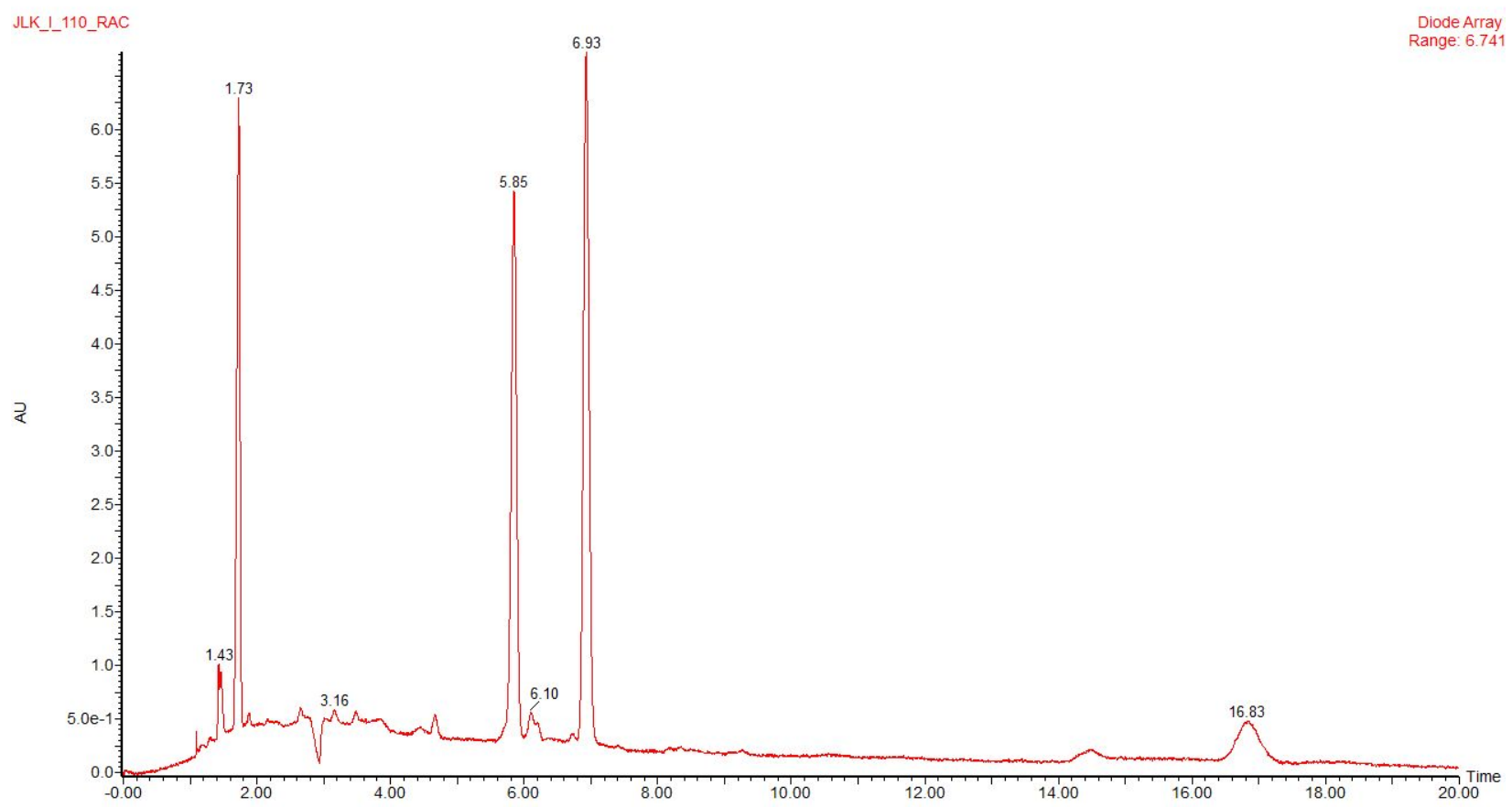

JLK_L186

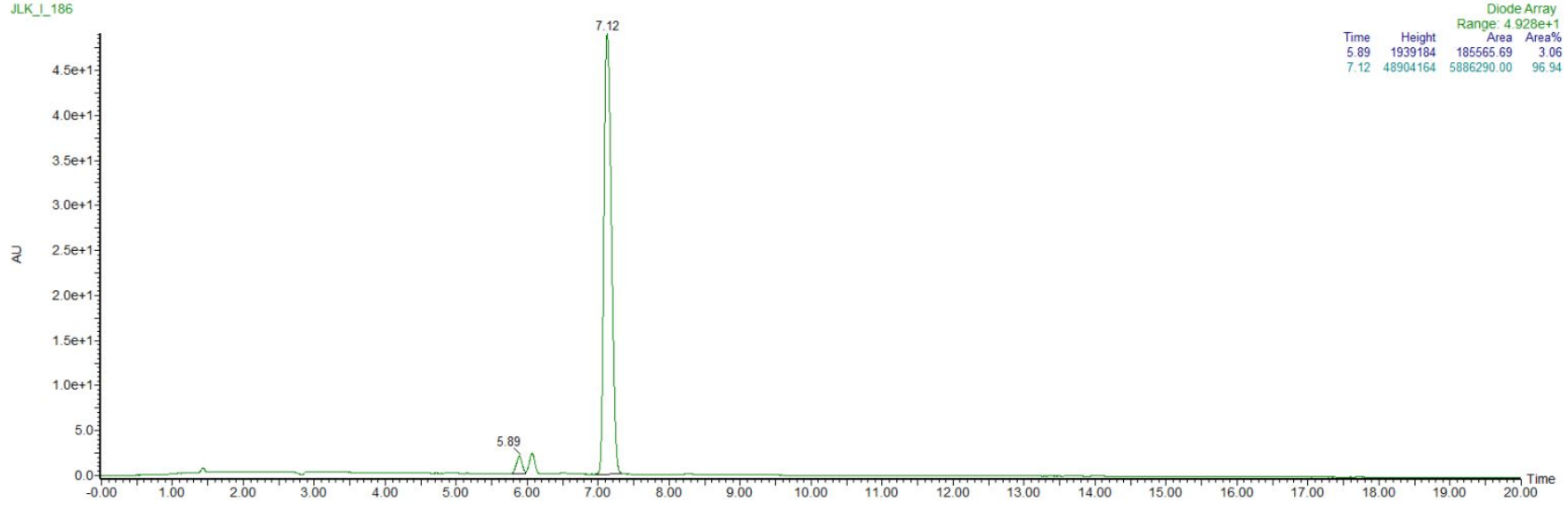


Supporting Information

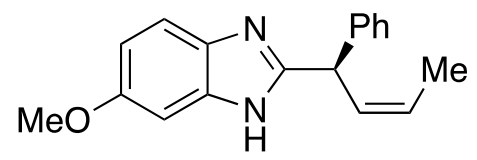

10

JLK_I_042_rac_meo
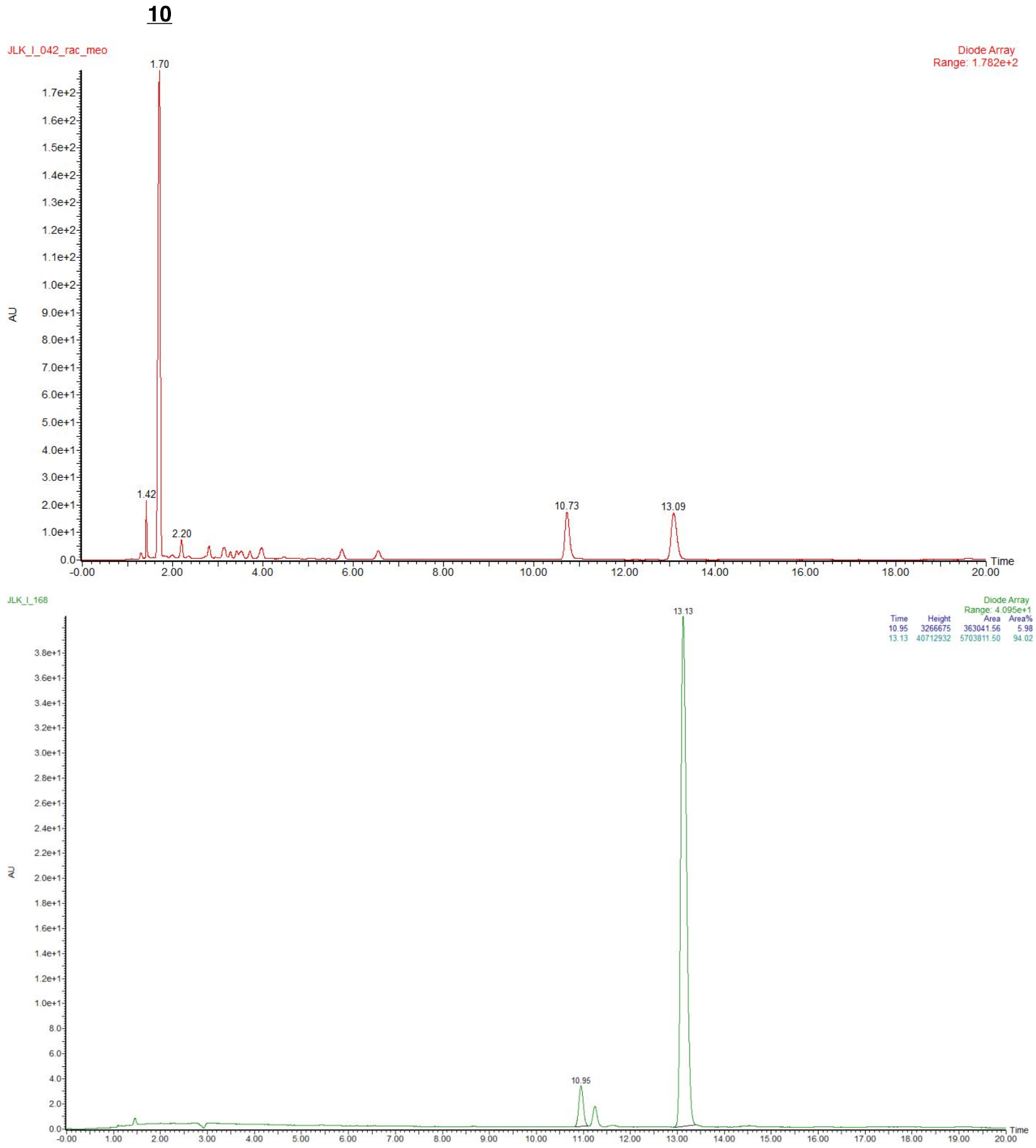
Supporting Information<smiles>C/C=C\C(c1ccccc1)c1nc2ccc(-c3cccs3)cc2[nH]1</smiles>

11
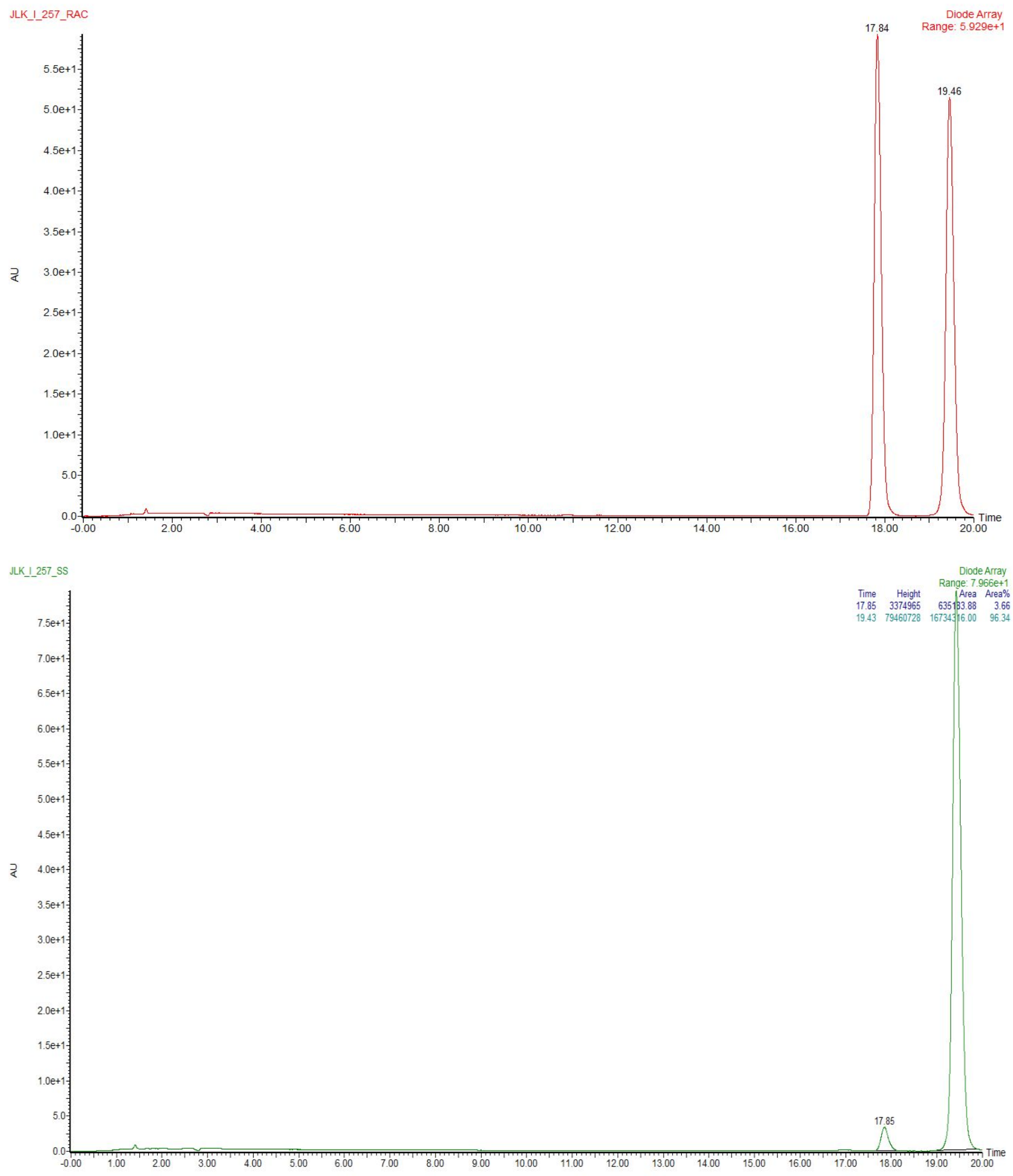


\section{Supporting Information}<smiles>C/C=C\C(c1ccccc1)c1nc2ccc(Cl)cc2[nH]1</smiles>

12
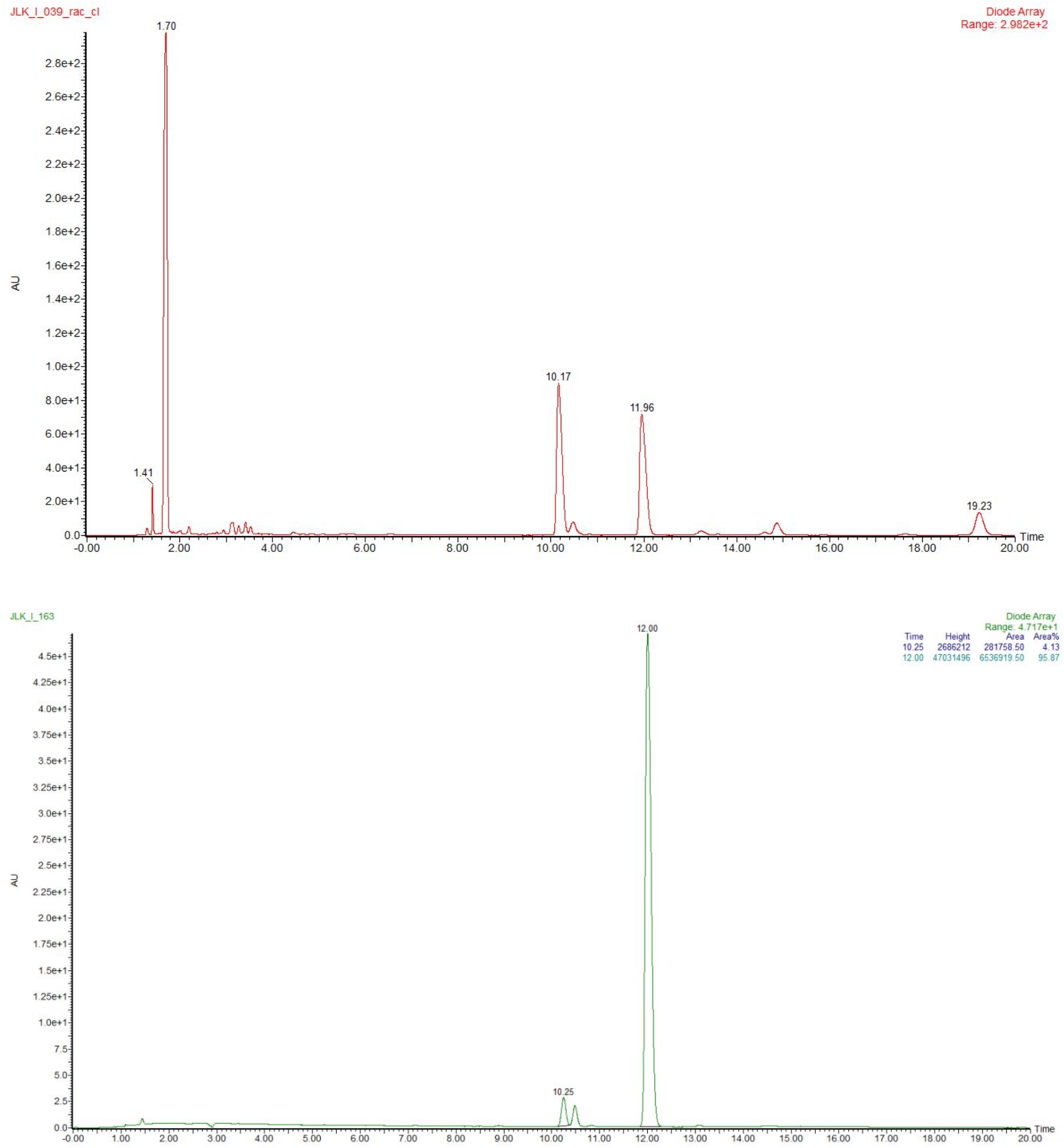
Supporting Information

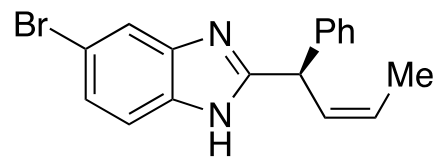

13

JLK_I_060_rac_br

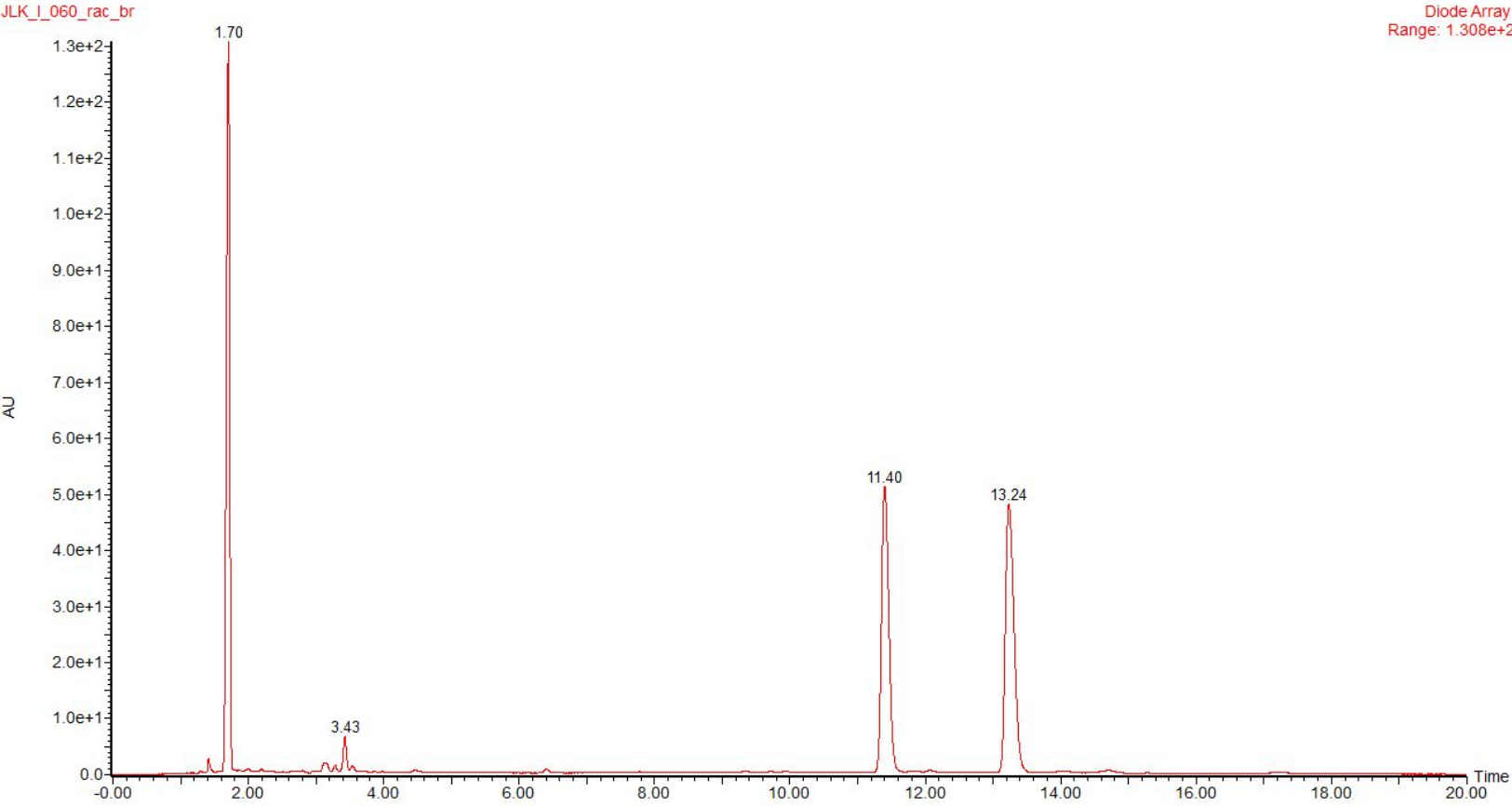
JLK_L_164

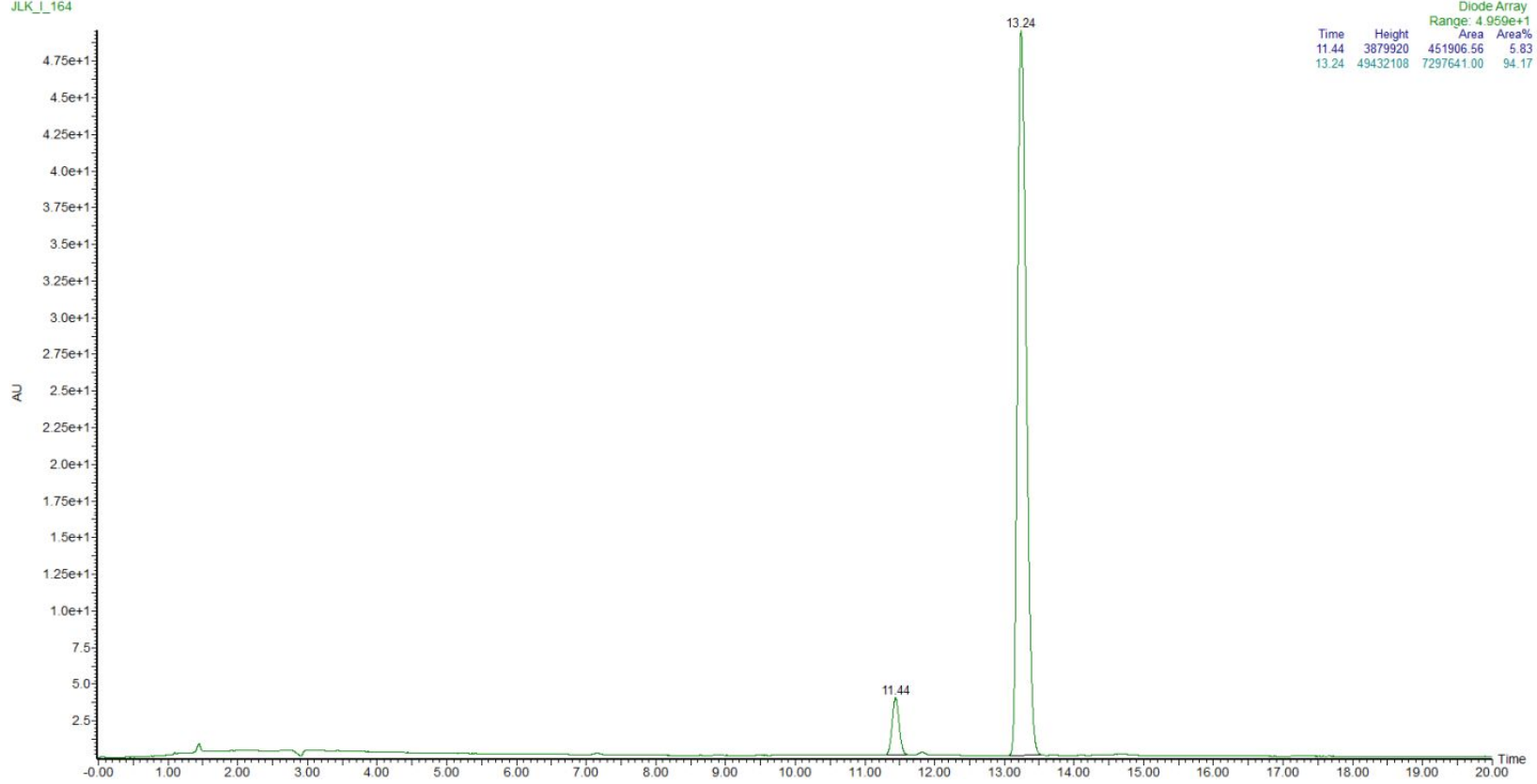


Supporting Information

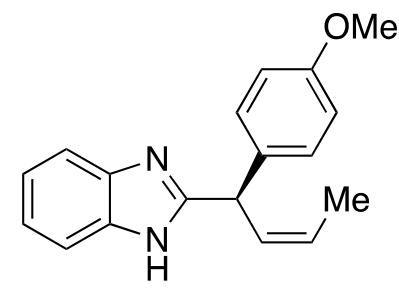

$\underline{14}$

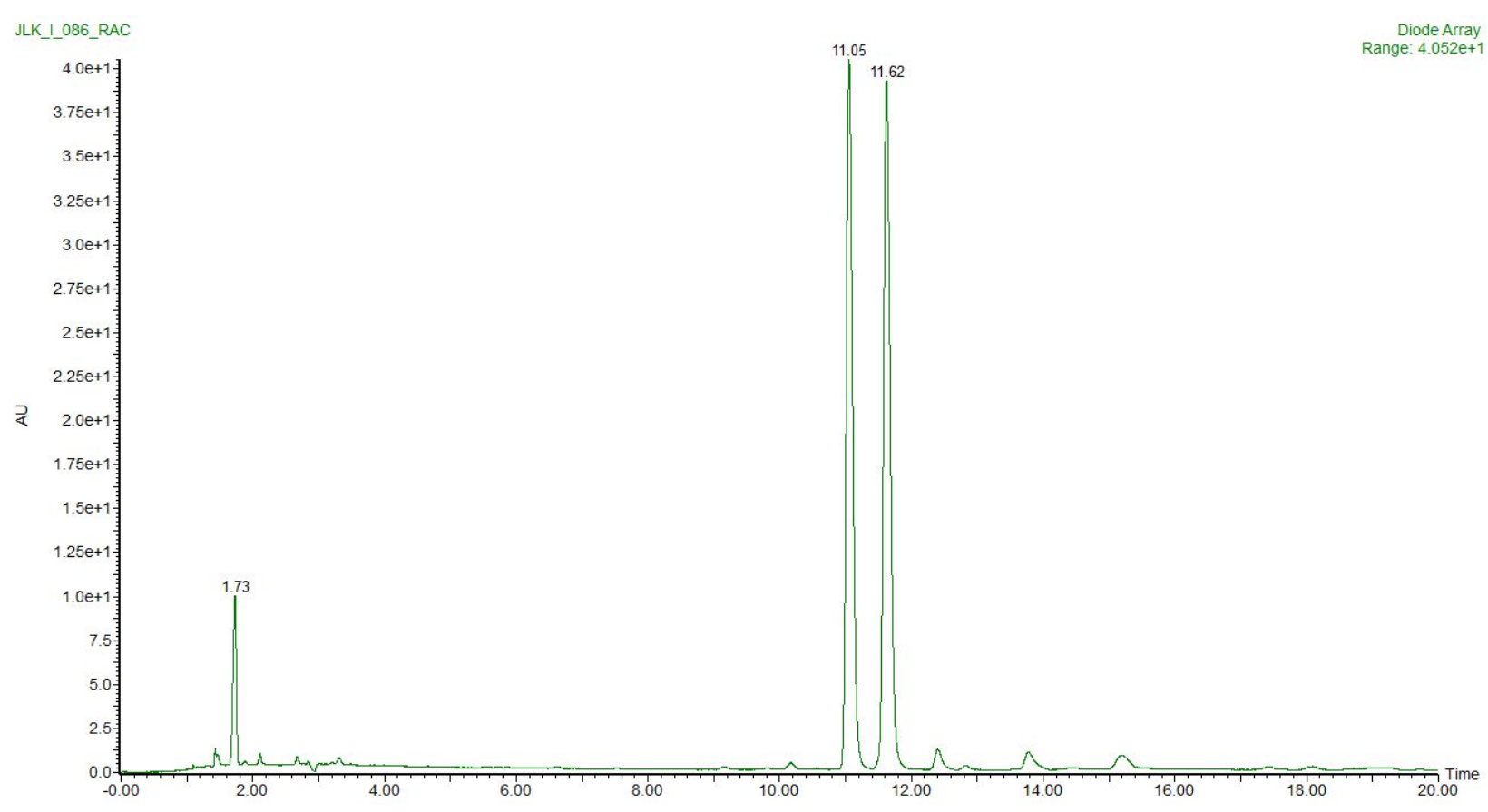
JLK_L_180

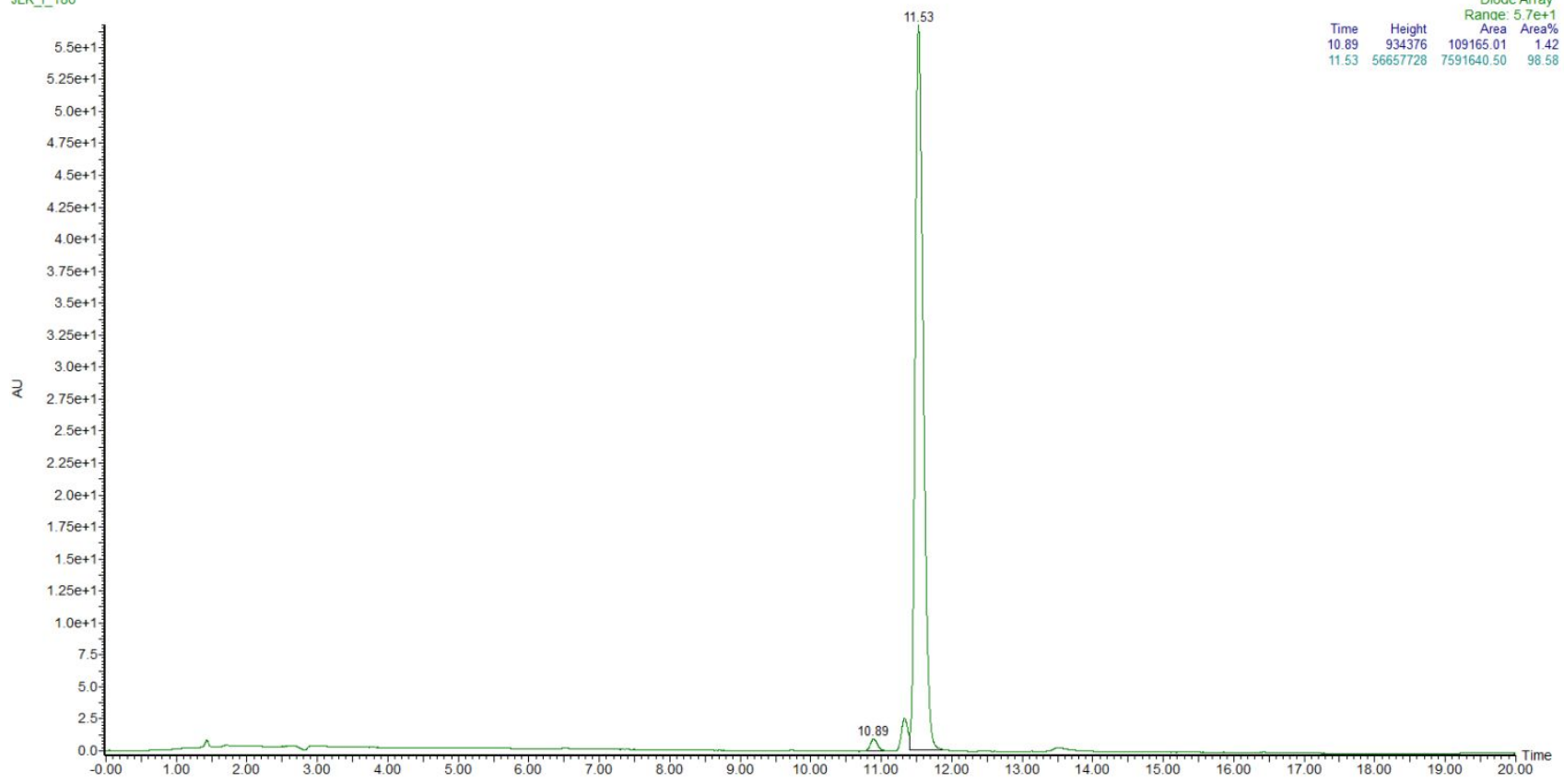




\section{Supporting Information}

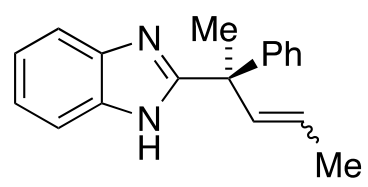

15

DAD1 B, Sig=254,8 Ref=360,100 (LEVIIHHD 2020-06-16 15-15-22\JLK-I-079 RAC85.D)

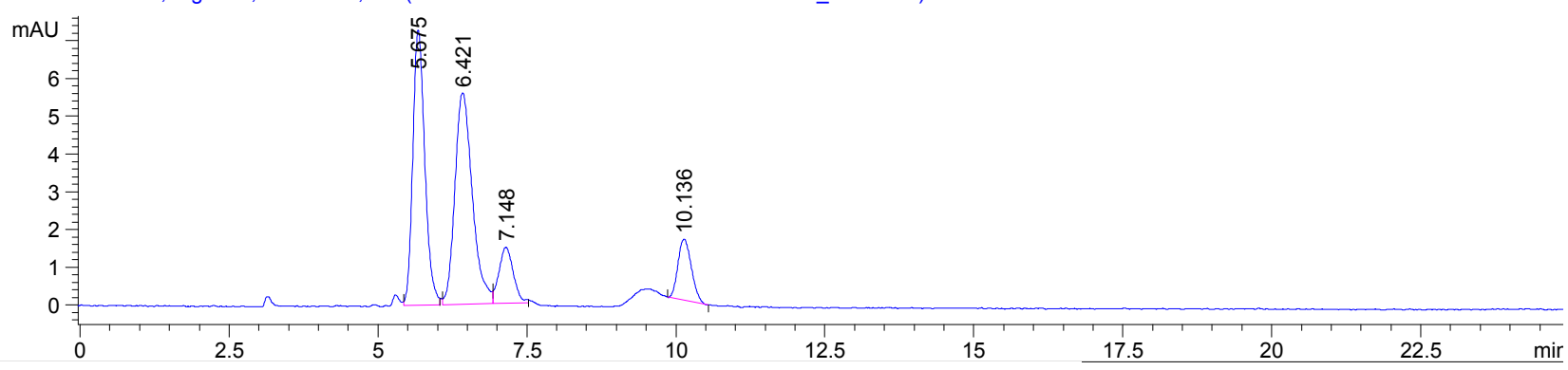

Signal 2: DAD1 B, Sig=254, 8 Ref=360, 100

\begin{tabular}{|c|c|c|c|c|c|c|}
\hline $\begin{array}{c}\text { Peak } \\
\#\end{array}$ & $\begin{array}{c}\text { RetTime } \\
\text { [min] }\end{array}$ & Type & $\begin{array}{l}\text { Width } \\
\text { [min] }\end{array}$ & $\begin{array}{c}\text { Area } \\
{\left[\mathrm{mAU}^{\star} \mathrm{s}\right]}\end{array}$ & $\begin{array}{l}\text { Height } \\
\text { [mAU] }\end{array}$ & $\begin{array}{c}\text { Area } \\
\frac{8}{\gamma}\end{array}$ \\
\hline---1 & ------- & & 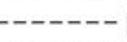 & -------- & -------1 & $-------\mid$ \\
\hline 1 & 5.675 & $\mathrm{BB}$ & 0.2156 & 102.20571 & 7.28937 & 38.2547 \\
\hline 2 & 6.421 & $\mathrm{BB}$ & 0.3087 & 114.56918 & 5.59960 & 42.8822 \\
\hline 3 & 7.148 & $\mathrm{BB}$ & 0.2482 & 24.89992 & 1.48061 & 9.3198 \\
\hline 4 & 10.136 & $\mathrm{BB}$ & 0.2429 & 25.49686 & 1.62604 & 9.5433 \\
\hline
\end{tabular}

DAD1 B, Sig=254,8 Ref=360,100 (LEVIIHHD 2020-06-16 15-15-22\JLK-I-205.D)

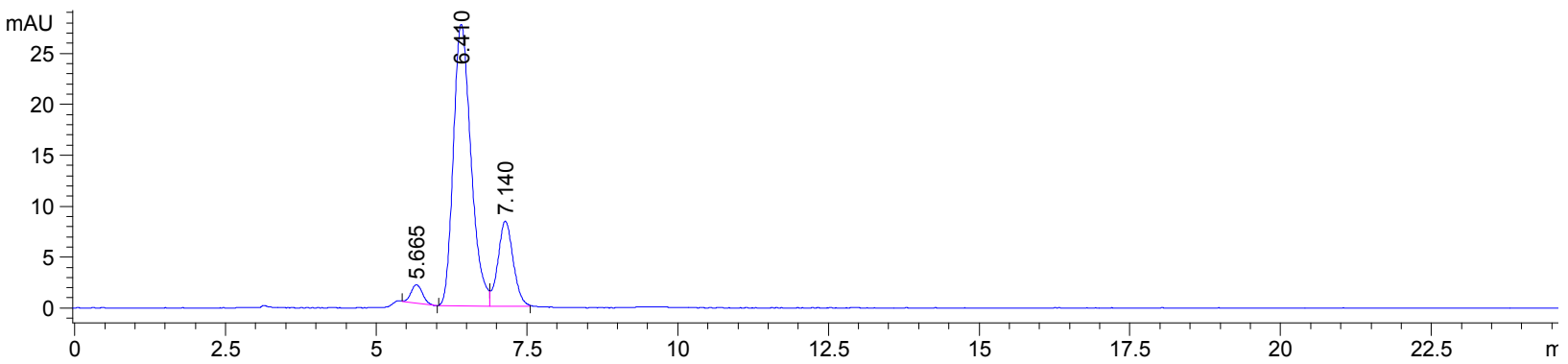

Signal 2: DAD1 B, Sig=254,8 Ref=360, 100

$\begin{array}{cccccc}\begin{array}{c}\text { Peak } \\ \text { \# }\end{array} & \begin{array}{c}\text { RetTime Type } \\ \text { [min] }\end{array} & \begin{array}{c}\text { Width } \\ {[\mathrm{min}]}\end{array} & \begin{array}{c}\text { Area } \\ {\left[\mathrm{mAU}{ }^{*} \mathrm{~S}\right]}\end{array} & \begin{array}{c}\text { Height } \\ {[\mathrm{mAU}]}\end{array} & \begin{array}{c}\text { Area } \\ \%\end{array} \\ \begin{array}{r}\text { [mind } \\ 1\end{array} & 5.665 \mathrm{BB} & 0.2067 & 24.06004 & 1.81427 & 3.2743 \\ 2 & 6.410 \mathrm{BV} & 0.3137 & 562.95508 & 27.63331 & 76.6125 \\ 3 & 7.140 \mathrm{VB} & 0.2681 & 147.79326 & 8.36795 & 20.1132\end{array}$


Supporting Information

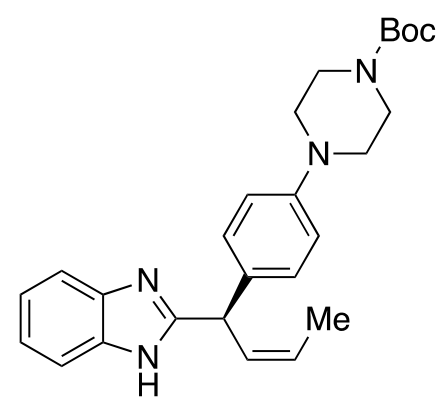

16
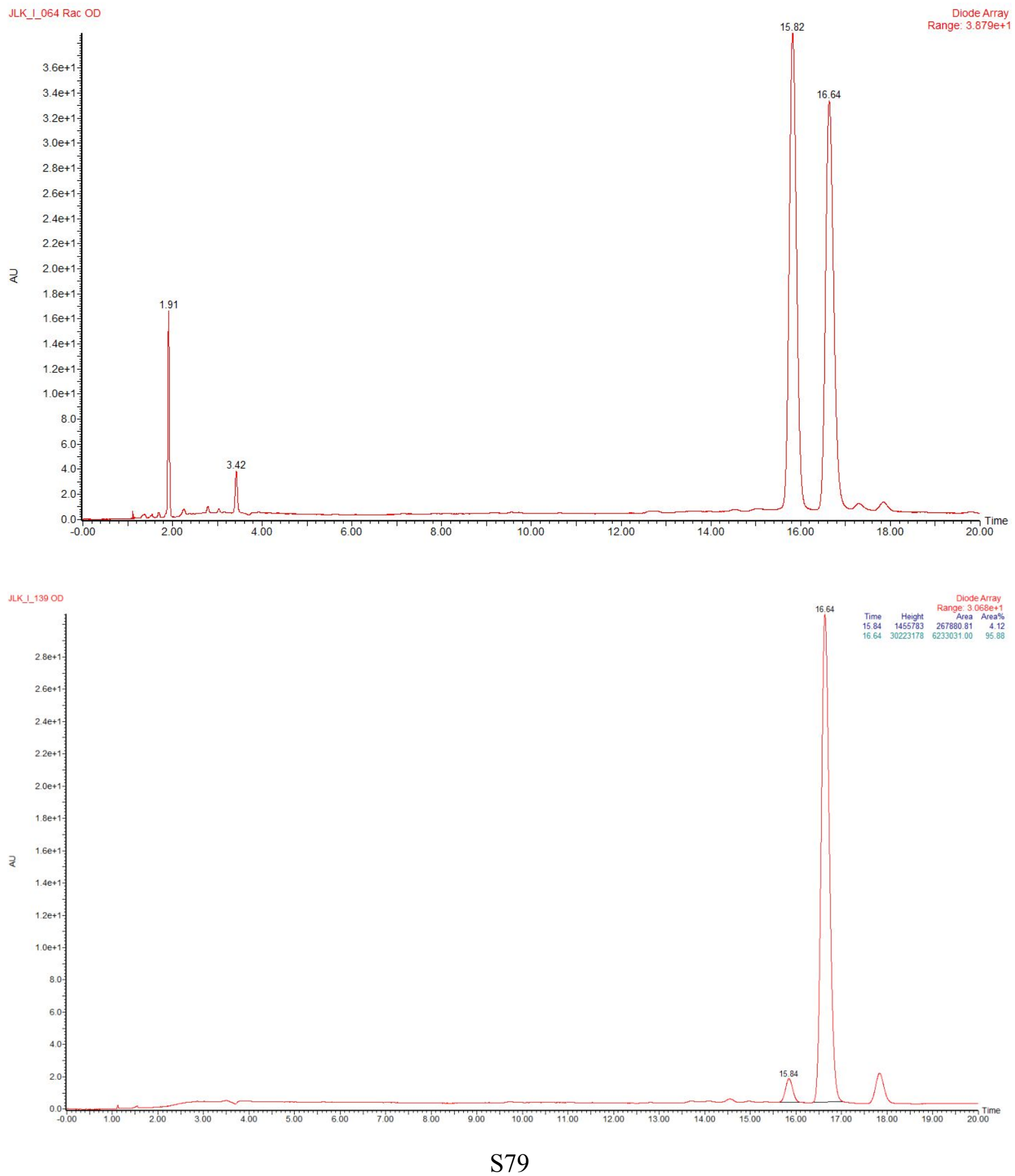
Supporting Information

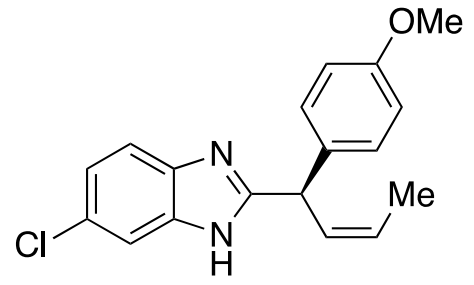

17
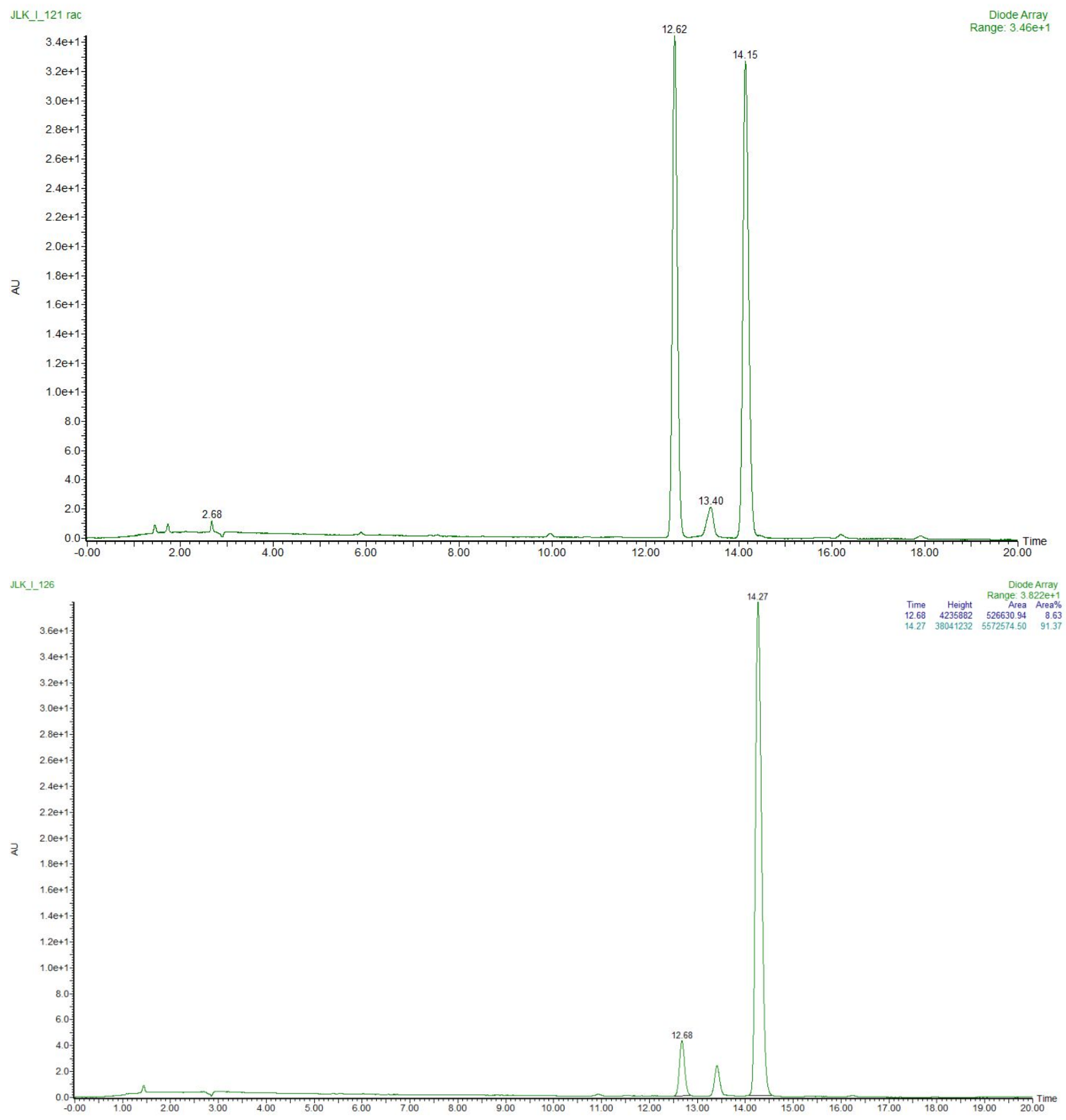
Supporting Information

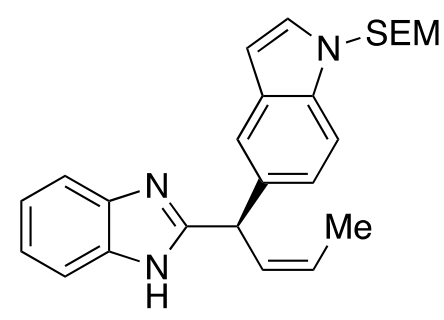

$\underline{18}$
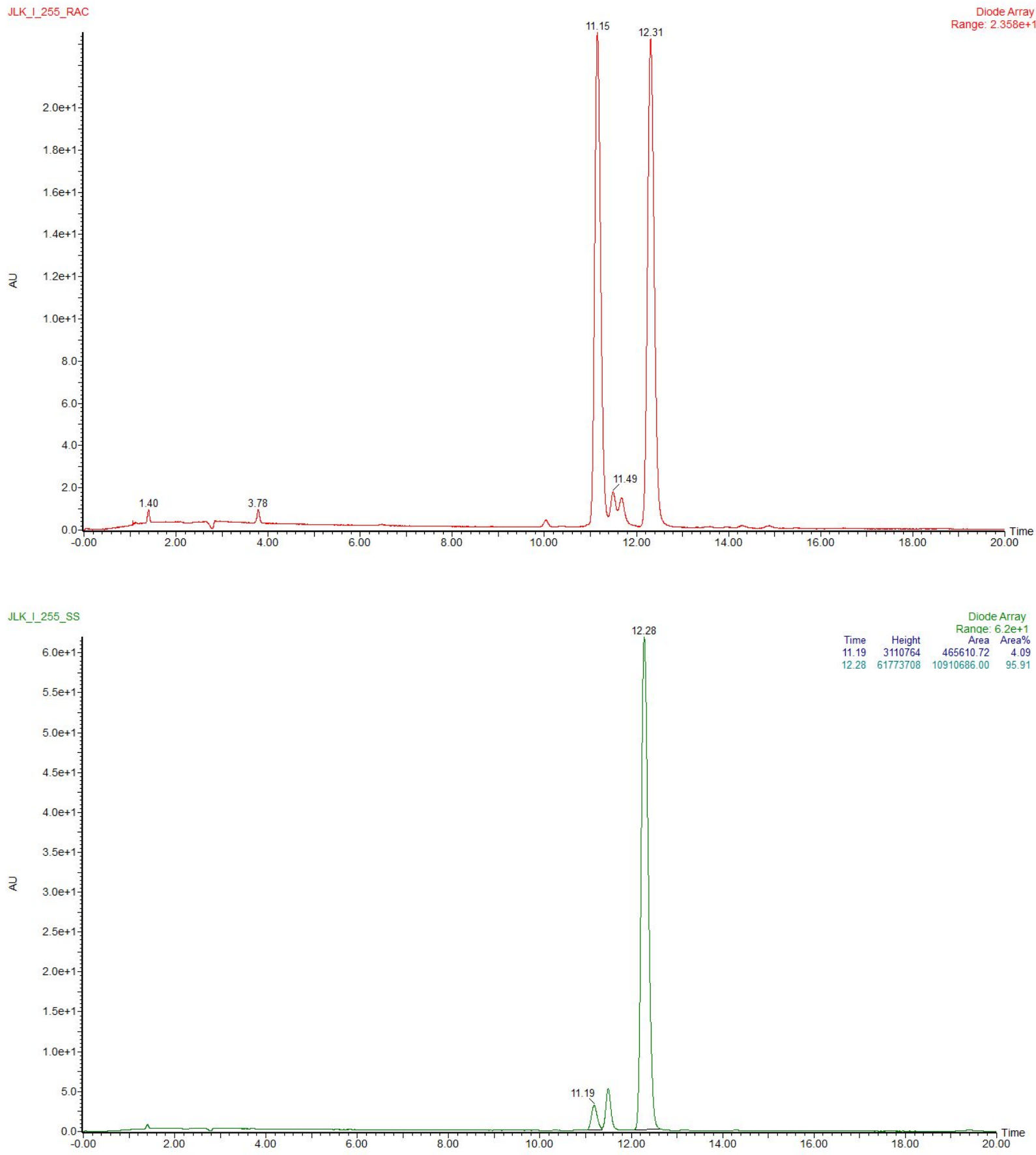


\section{Supporting Information}

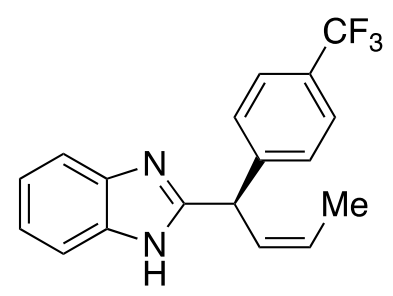

19
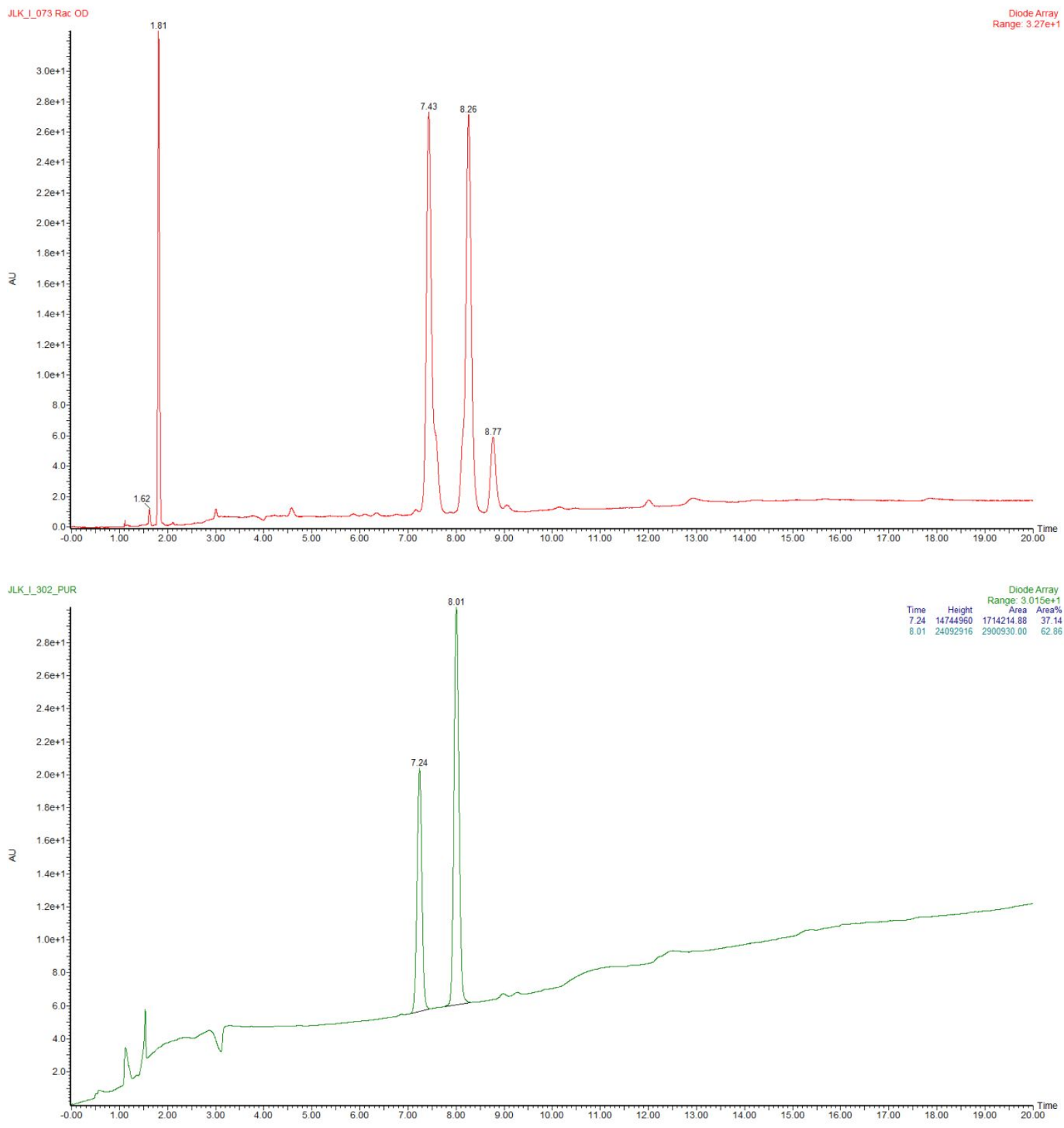
Supporting Information

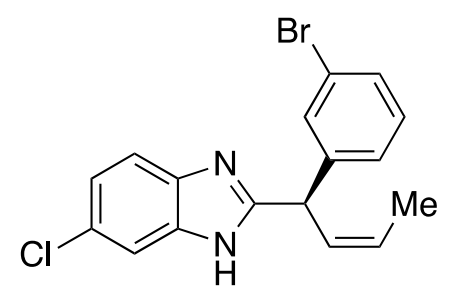

20

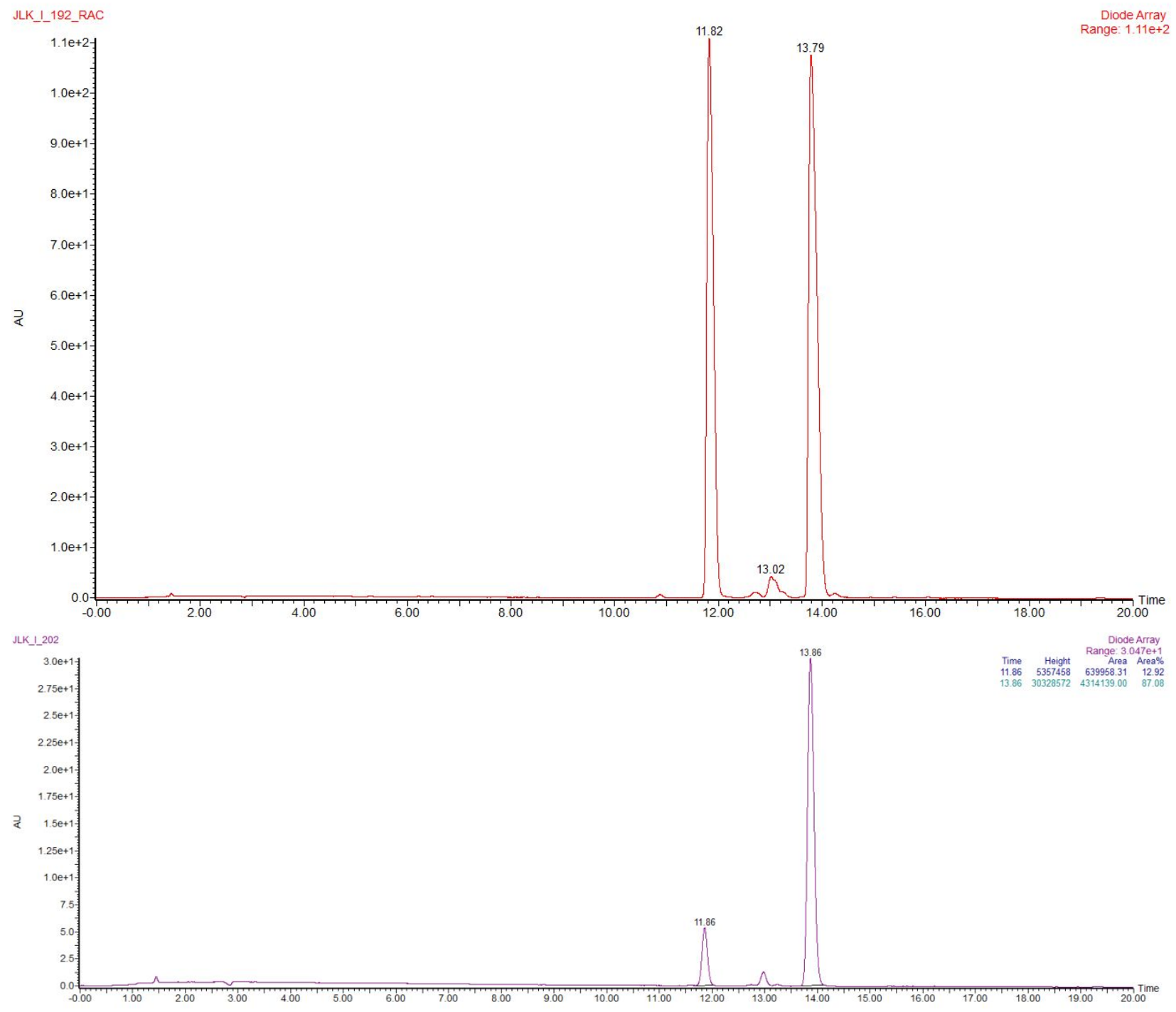


Supporting Information

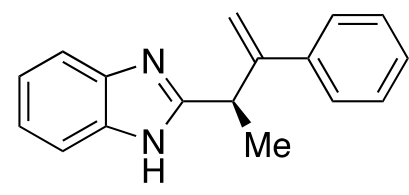

$\underline{21}$

JLK_I_078_RAC_

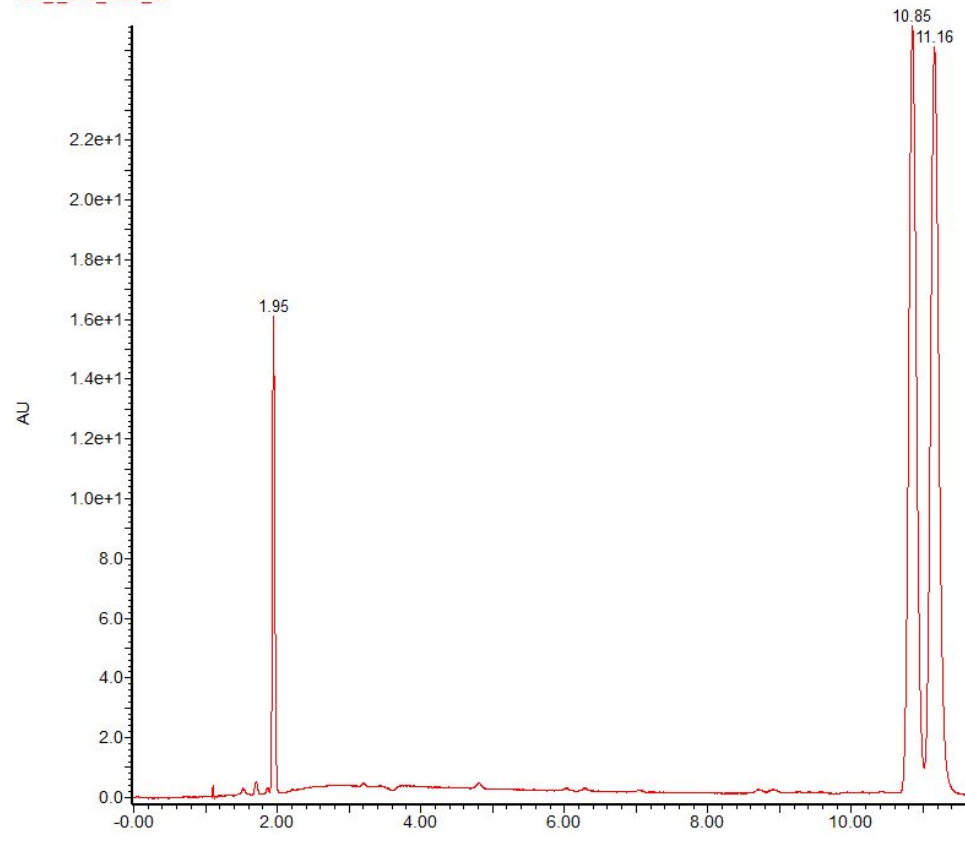

Diode Array

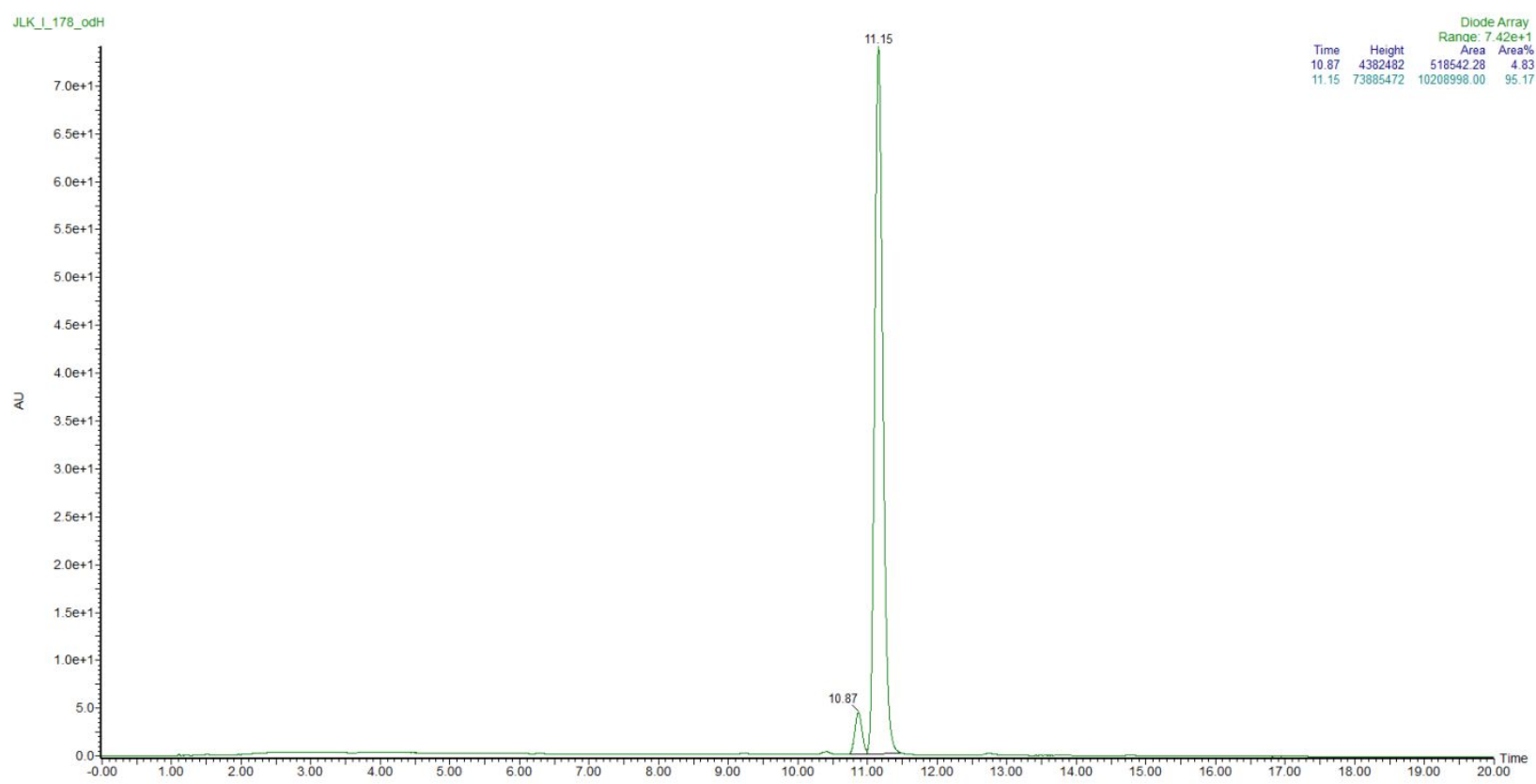


Supporting Information

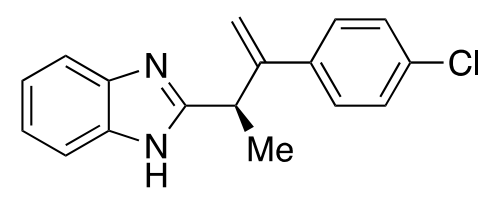

22

JLK_I_090_RAC

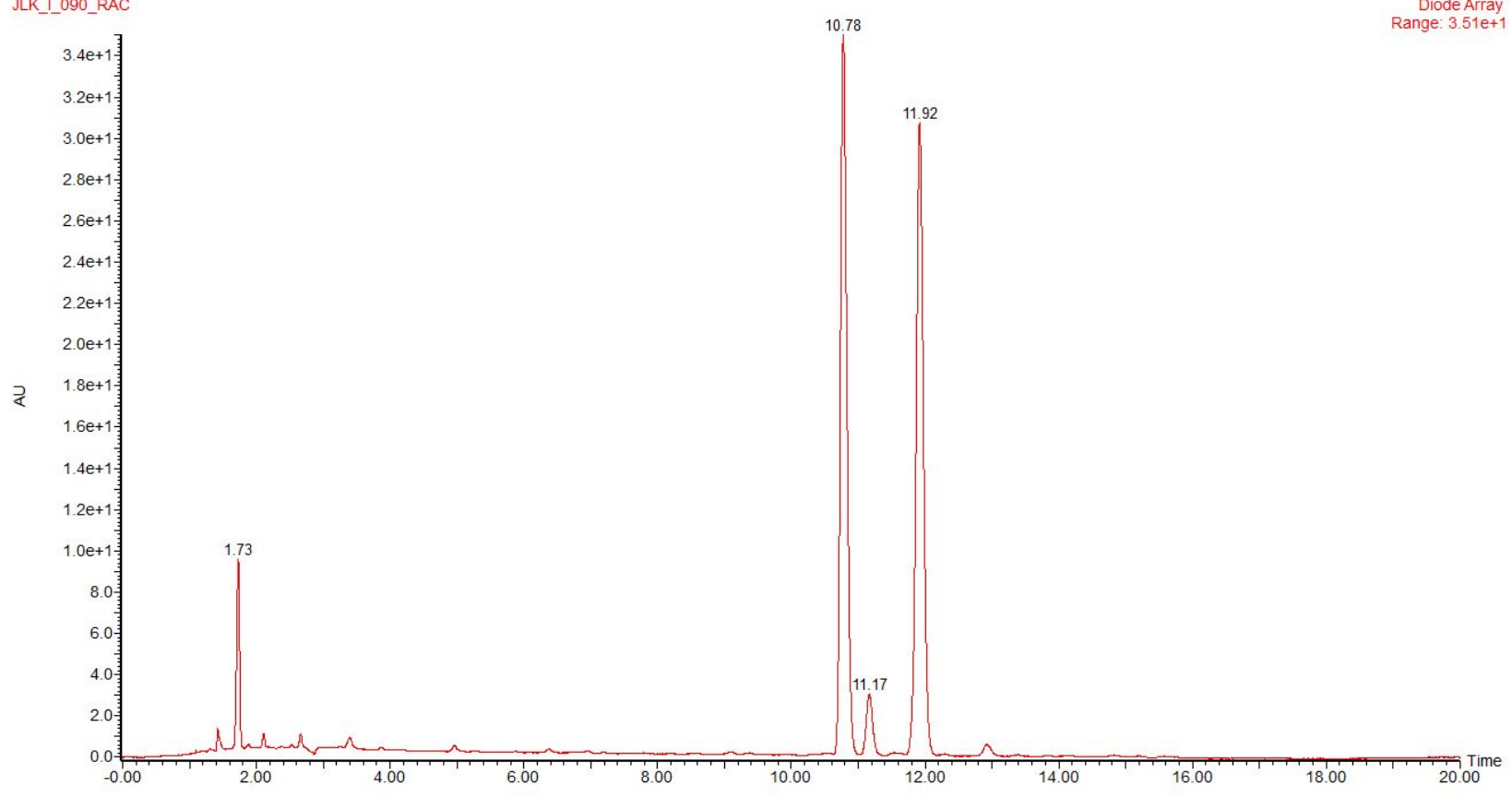

JLK-1-208

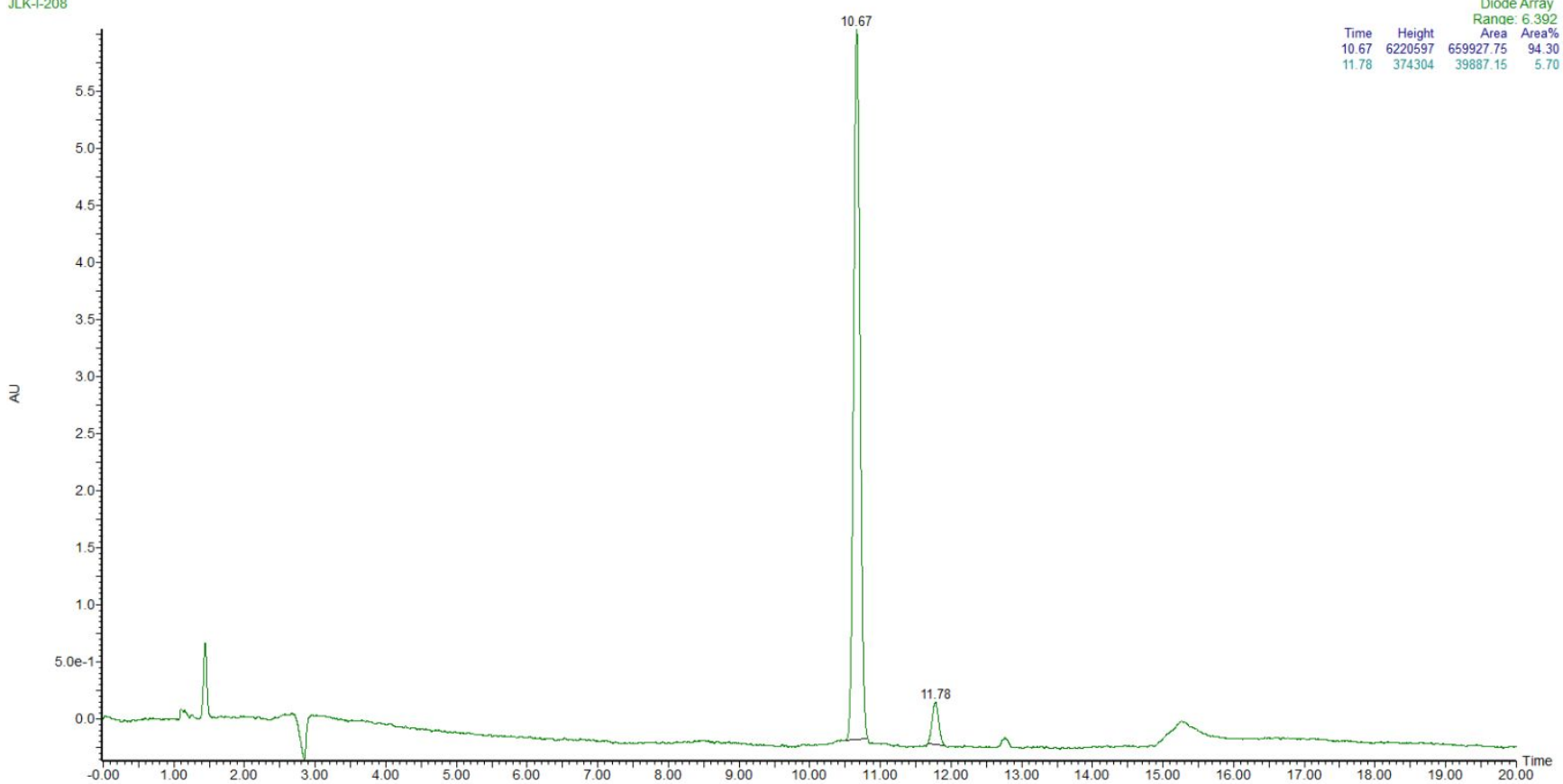


Supporting Information

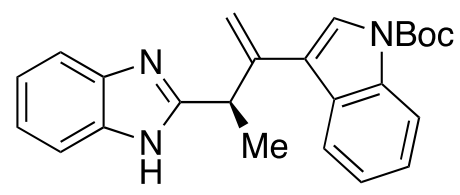

23

JLK_I236_rac

$2.0 \mathrm{e}+1$
$1.8 \mathrm{e}+1$
$1.6 \mathrm{e}+1$
$1.4 \mathrm{e}+1$
$1.2 \mathrm{e}+1$
$1.0 \mathrm{e}+1$
8.0
6.0
4.0
2.0
0.0

JLK+-238

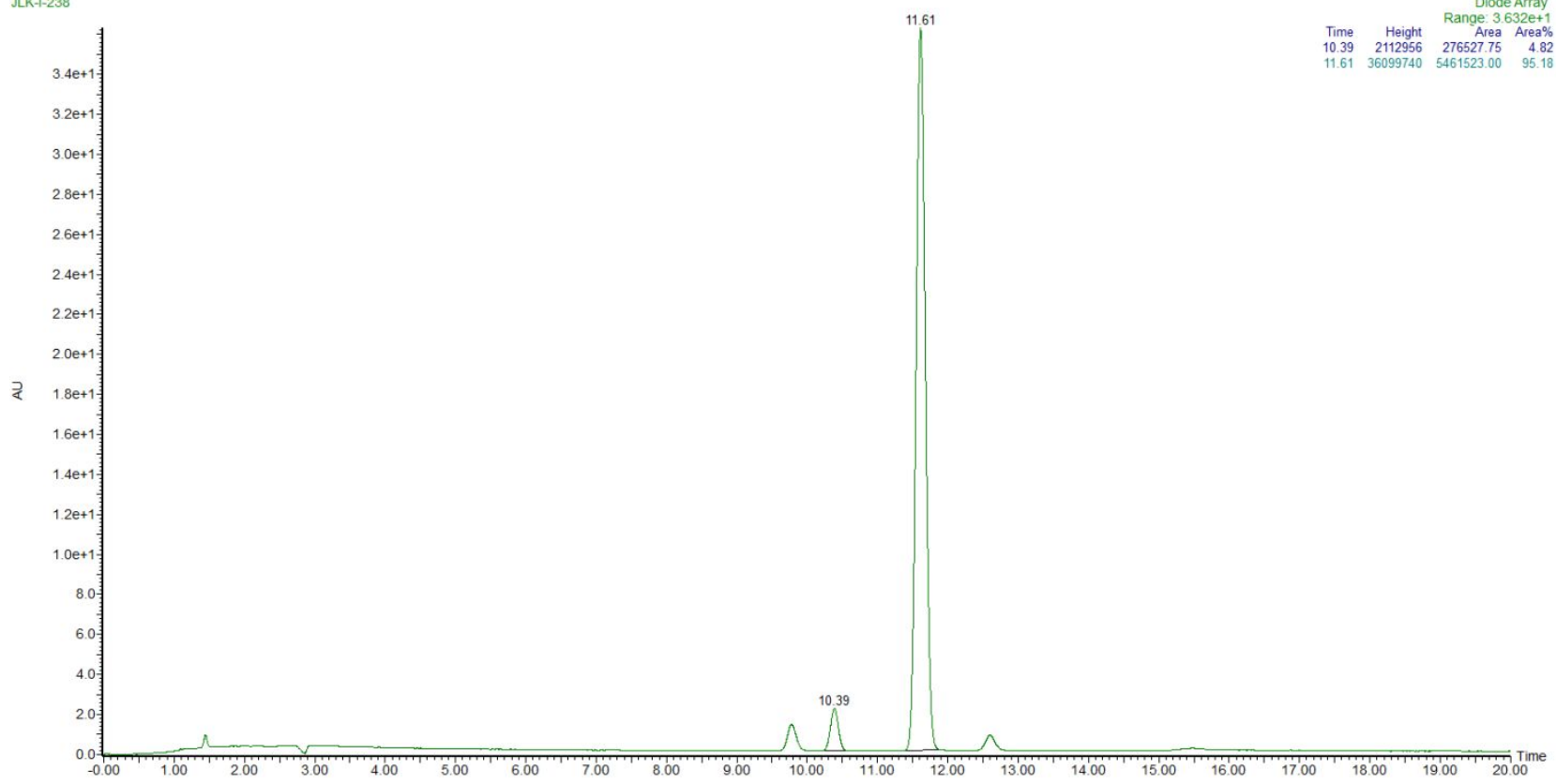




\section{Supporting Information}<smiles>C=C(c1ccccc1)[C@H](C)c1nc2ccc(C(F)(F)F)cc2[nH]1</smiles>

\section{$\underline{24}$}

JLK___128 rac
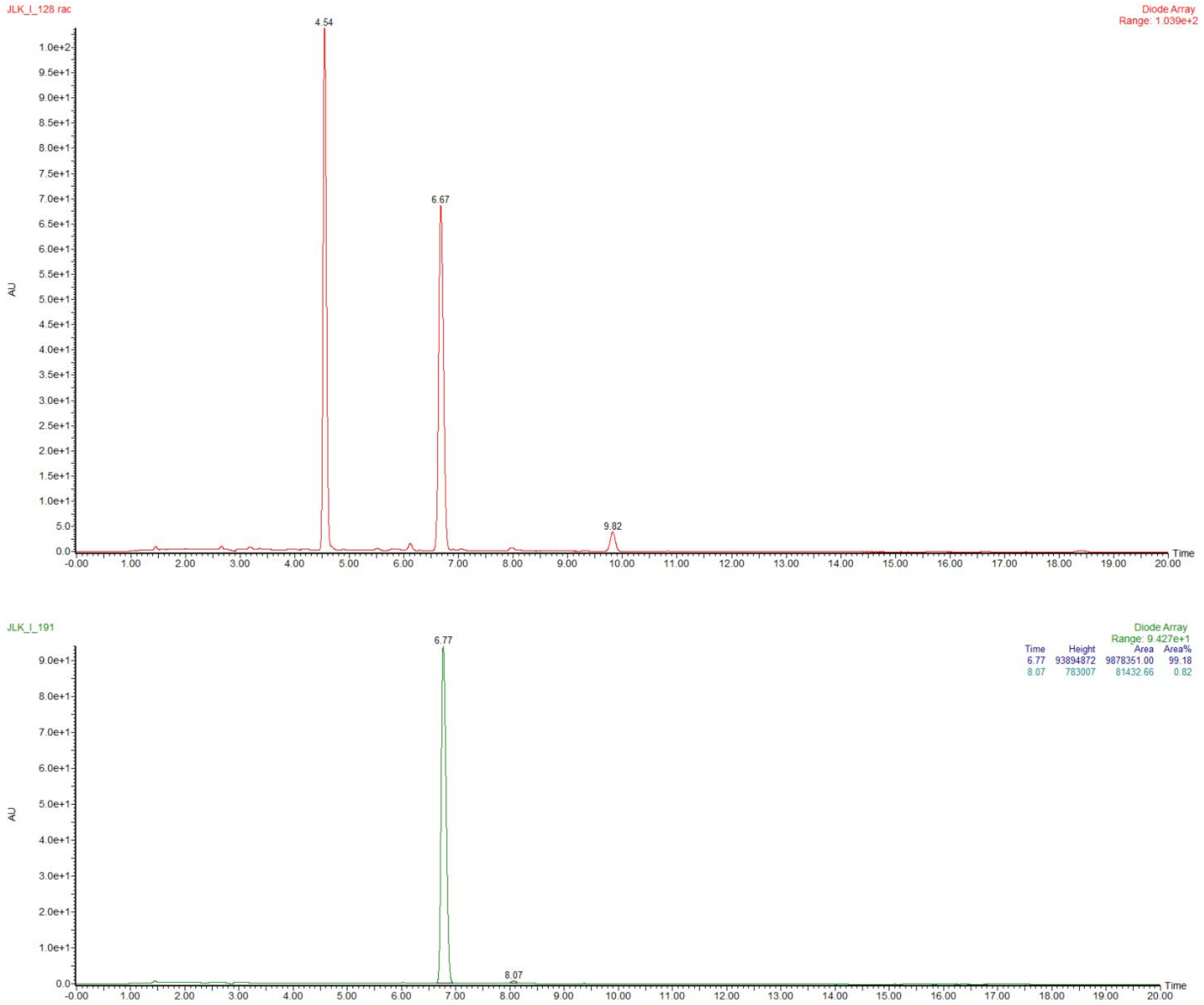


\section{Supporting Information}

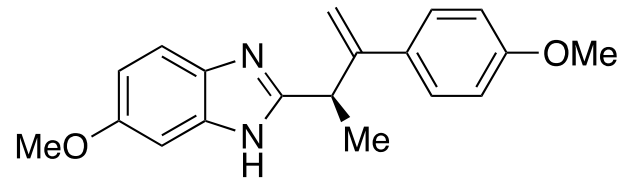

$\underline{25}$

JLK_I_147 Rac

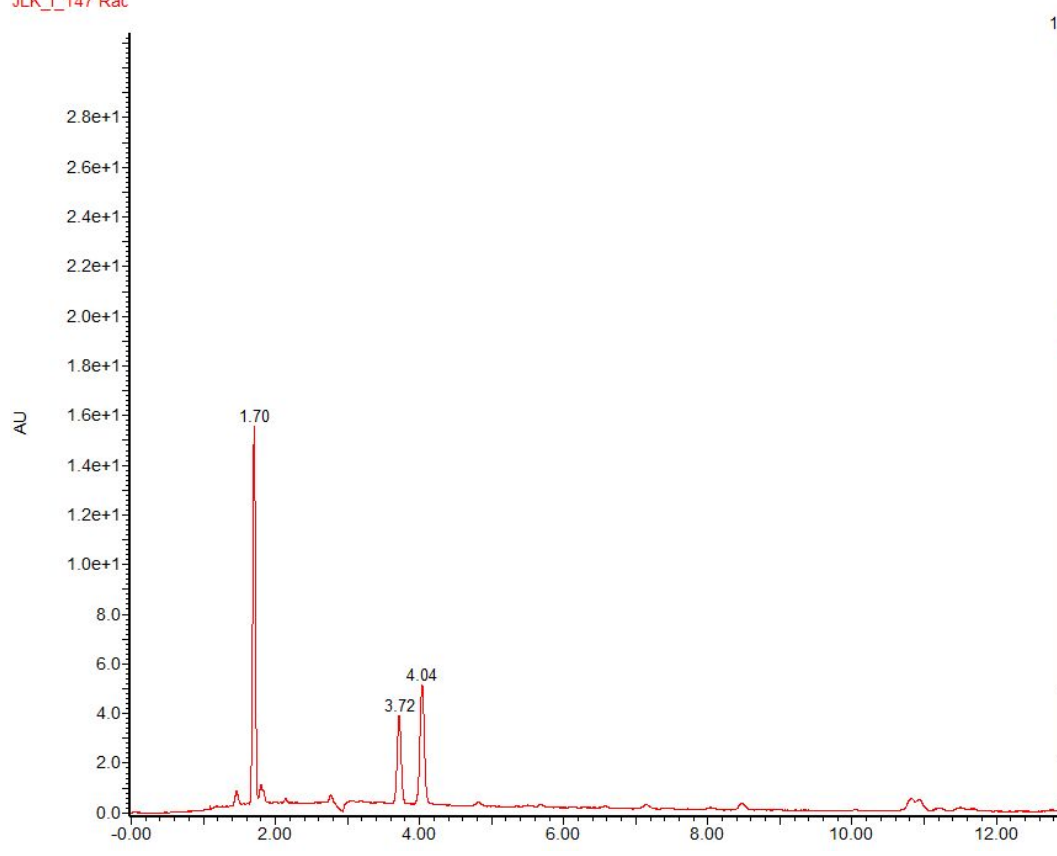
JLK_I_162

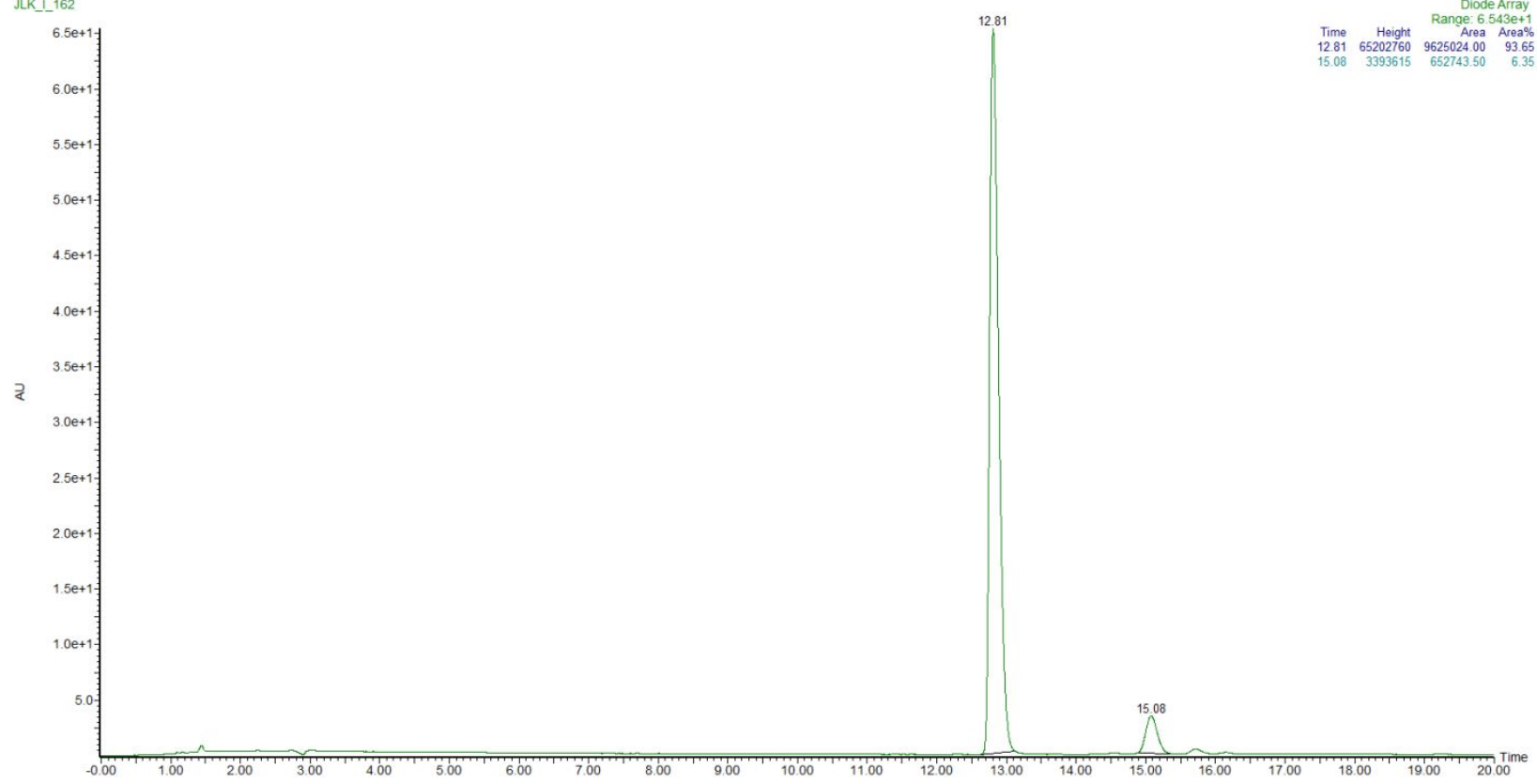

